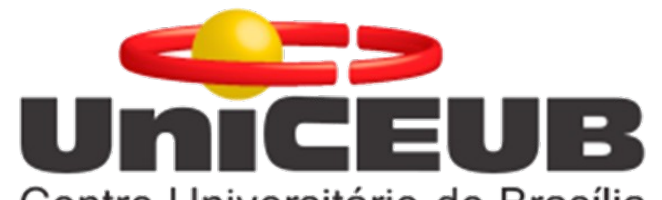

Centro Universitário de Brasília

CENTRO UNIVERSITÁRIO DE BRASÍLIA - UnICEUB FACULDADE DE TECNOLOGIA E CIÊNCIAS SOCIAIS APLICADAS FATECS

PROGRAMA DE INICIAÇÃO CIENTÍFICA

AMANDA DA SILVA LOPES

MENSAGENS PELA (E PELA) CIDADE -

A HUMANIZAÇÃO DE BRASÍLIA - DF VIA INTERVENÇÕES VISUAIS NA ASA SUL - BSB - DF

BRASÍLIA - DF 2016 


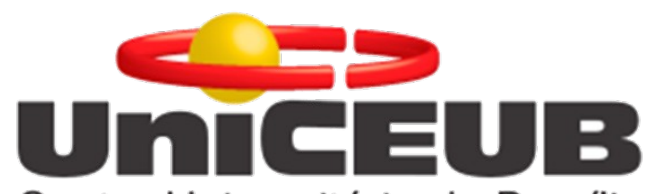

Centro Universitário de Brasília

\section{AMANDA DA SILVA LOPES}

MENSAGENS PELA (E PELA) CIDADE A HUMANIZAÇÃO DE BRASÍLIA - DF VIA INTERVENÇÕES VISUAIS NA ASA SUL - BSB - DF

Relatório final de pesquisa de Iniciação Científica apresentado à Assessoria de Pós-Graduação e Pesquisa pela Faculdade de Tecnologia e Ciências Sociais Aplicadas - FATECS

Orientação: Ursula Betina Diesel

\section{BRASÍLIA - DF}




\title{
MENSAGENS PELA (E PELA) CIDADE - A HUMANIZAÇÃO DE BRASÍLIA - DF VIA INTERVENÇÕES VISUAIS NA ASA SUL - BSB - DF
}

\author{
Nome do aluno - Amanda da Silva Lopes \\ manda.slopes@gmail.com
}

Nome da orientadora - Ursula Betina Diesel

ursuladiesel@gmail.com

\section{RESUMO:}

O presente projeto caracteriza-se pelo levantamento fotográfico de mensagens manifestadas nos espaços públicos de Brasília, como muros, paredes, asfalto, calçadas, especialmente nas passarelas subterrâneas da Asa Sul, do Plano Piloto, em Brasília - DF, na perspectiva de que essas intervenções visuais urbanas atuem como promotoras de afeto em relação à cidade e no seu espaço. O objetivo é, a partir do levantamento imagético, analisar as mensagens para constatar o percurso comunicativo traçado na direção do afeto. A metodologia utilizada para tanto foi, primeiramente, a revisão bibliográfica de referências sobre o tema, via autores como Bordenave, Russi, Augè, Gehl e Gemzoe, Habermas, Mcluhan, Montane, Santaella, Foucault; depois, o levantamento fotográfico de intervenções; a análise via dispositivos teórico-metodológicos da semiótica peirceana e da análise do discurso de vertente francesa; e, ao final, a aplicação de questionário, com questões fechadas e abertas, a transeuntes das passarelas. Como resultados tem-se cerca de 250 intervenções ${ }^{1}$ e seu contexto fotografados, o mapa da das área com a marcação mesmas, a análise de parte das imagens (cerca de 30), escolhidas por representarem aquelas mais recorrentes e/ou impactantes. O dispositivo semiótico permite identificar a predominância de elementos icônicos (figurativos) de seres vivos, a técnica do grafite e da pichação como elemento indicial mais recorrente, e a complementariedade bastante presente do elemento simbólico verbal, que direciona a interpretação dos demais aspectos perceptíveis. Cromaticamente, vigoram cores fortes e contrastantes. No geral, a interpretação das intervenções concentra-se em vivências pessoais e dicas de aspectos a considerar, em reflexão, sobre a qualidade de vida. O raciocínio foucaultiano reforça a relação das escolhas com o contexto das obras e aponta o propósito de positivar os ambientes em que são manifestas as mensagens, alegrando-os, buscando a quebra do deslocamento espacial rápido e automático, e estabelecendo uma conversa com e entre os transeuntes/habitantes e a cidade. A partir da pesquisa de campo verificou-se que o local é intensamente 1 
demarcado como um espaço de passagem, em geral caracterizada pela pressa, seja por exigências da rotina diária ou, especialmente, por insegurança. Tais aspectos dificultam a maior interação das pessoas com as mensagens. Mesmo assim, os respondentes, em geral, manifestaram a percepção de aspectos positivos e agradáveis em relação às intervenções no local. Portanto, é possível caracterizar a atuação dessas intervenções urbanas nas passarelas subterrâneas da Asa Sul do Plano Piloto, em Brasília - DF, como promotoras de afeto dentro da cidade e, também, em relação a ela.

Palavras-chave: Comunicação. Arte urbana. Afeto. 


\section{Sumário}

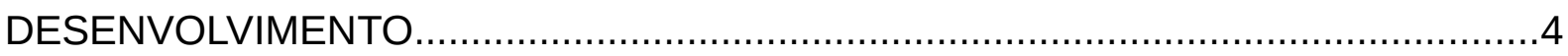

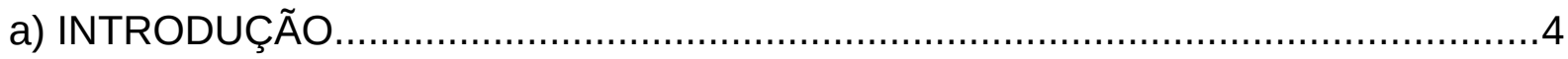

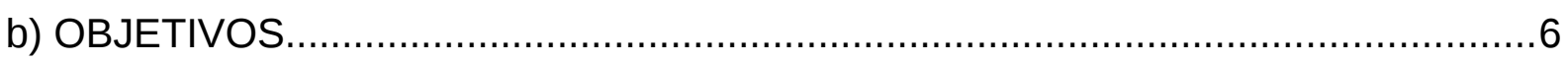

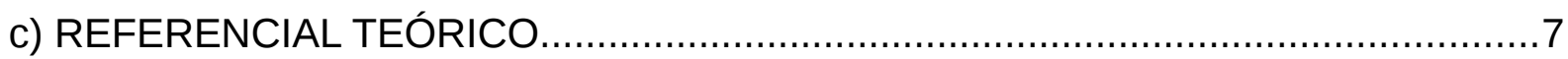

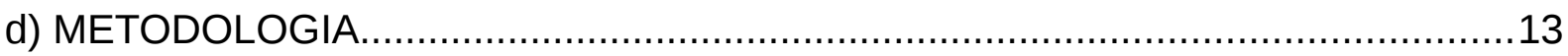

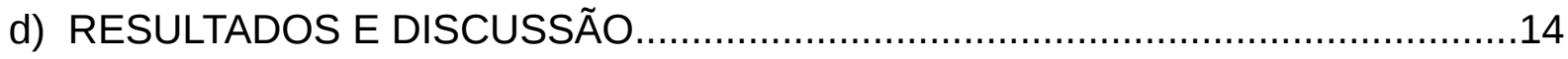

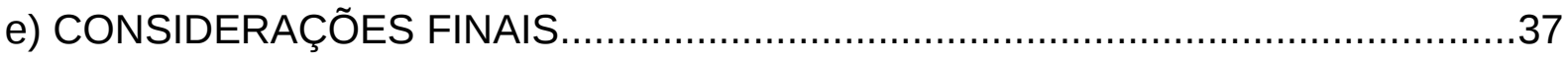

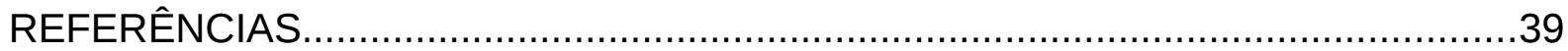

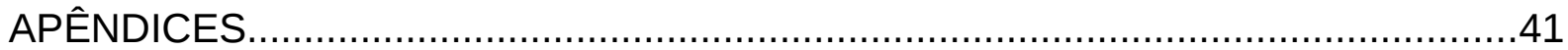




\section{LISTA DE FIGURAS}

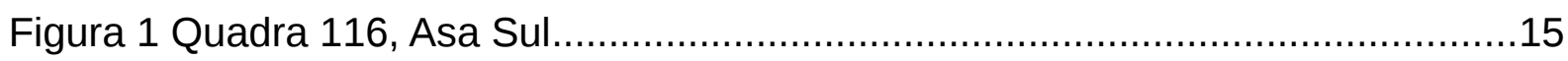

Figura 2 Quadra 116, Asa Sul............................................................ 16

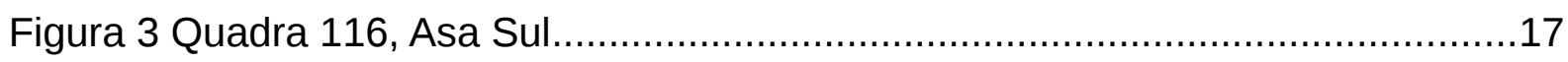

Figura 4 Quadra 114, Asa Sul...........................................................

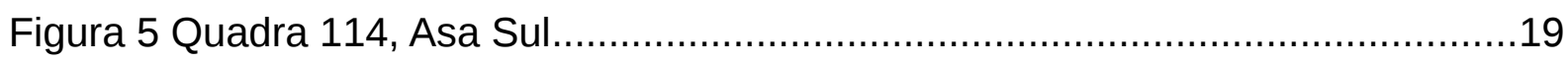

Figura 6 Quadra 114, Asa Sul.......................................................... 19

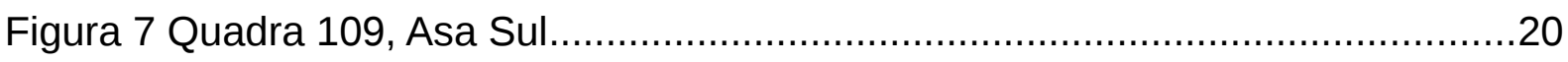

Figura 8 Quadra 114, Asa Sul.......................................................... 41

Figura 9 Quadra 114, Asa Sul............................................................. 42

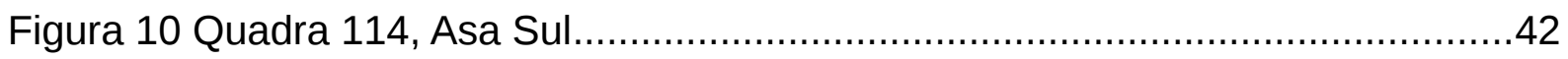

Figura 11 Quadra 109, Asa Sul.......................................................... 43

Figura 12 Quadra 109, Asa Sul........................................................... 44

Figura 13 Quadra 110/111, Asa Sul............................................................44

Figura 14 Quadra 110/111, Asa Sul...................................................... 45

Figura 15 Quadra 110/111, Asa Sul.......................................................46

Figura 16 Quadra 110/111, Asa Sul...................................................46

Figura 17 Quadra 110/111, Asa Sul.......................................................4

Figura 18 Quadra 110/111, Asa Sul.....................................................48

Figura 19 Quadra 108, Asa Sul........................................................... 48

Figura 20 Quadra 108, Asa Sul........................................................ 49

Figura 21 Quadra 108, Asa Sul..........................................................49

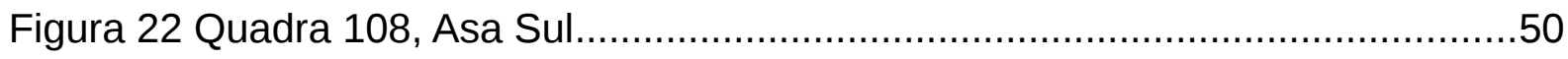

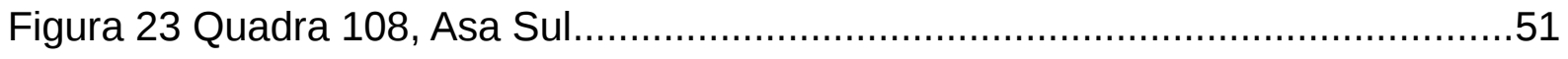

Figura 24 Quadra 106, Asa Sul.......................................................... 51

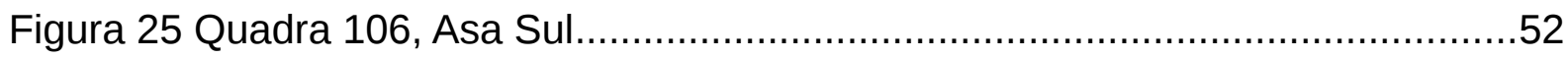




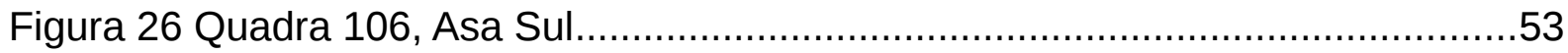

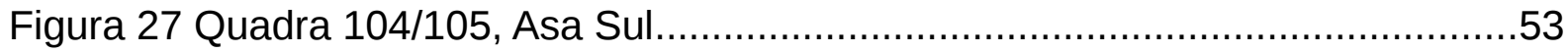

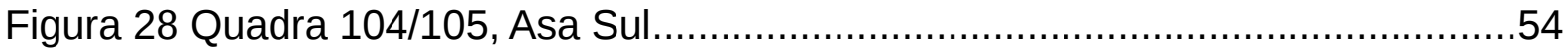

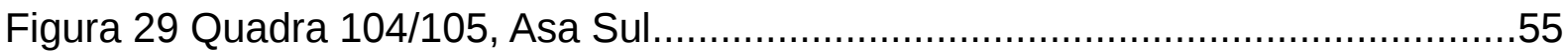

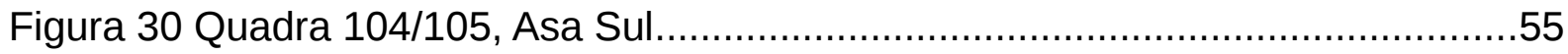

Figura 31Quadra 104/105, Asa Sul.........................................................56

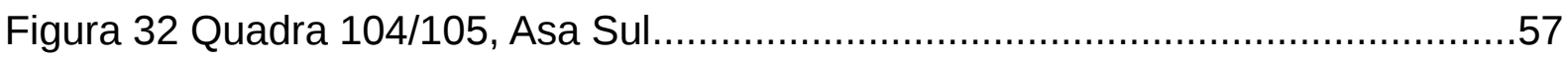

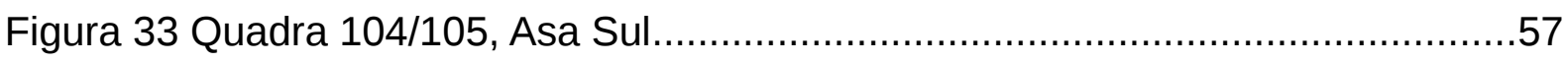

Figura 34 Quadra 102/103, Asa Sul.....................................................58

Figura 35 Quadra 102/103, Asa Sul....................................................59 


\section{DESENVOLVIMENTO}

\section{a) INTRODUÇÃO}

Tema: intervenções urbanas em Brasília

Objeto: Levantamento e estudo de mensagens manifestadas nos espaços públicos de Brasília, especificamente nas passarelas subterrâneas da Asa Sul, Plano Piloto, por indivíduos ou grupos com a finalidade de interagir com a cidade e seus habitantes promovendo reflexão e afeto.

Problema: Como mensagens expostas pela cidade podem atuar pela cidade e por sua humanização?

Brasília tem intervenções artísticas espalhadas pelo seu território, e seu projeto arquitetônico estrutura a cidade para carros e não para pessoas. Seus moradores são estereotipados como frios, aficionados por trabalho, distante do conceito de cidadãos que realmente vivem a cidade. A capital brasileira sofre com alguns problemas como qualquer outra cidade: falta de acesso ao ensino, hospitais públicos sem qualidade e a falta de planejamento urbano, o que ajuda a dificultar a vida dos moradores. Em contrapartida, é uma cidade desejada por muitos como moradia. Brasília, enquanto espaço público, deve abrigar e representar seus moradores, e as intervenções visuais urbanas são uma forma de as pessoas verem a cidade como espaço de pluralidade que acolhe os cidadãos. Essa forma de manifestação pode ser percebida como um modo de os moradores se identificarem com as questões corriqueiras da cidade e pode, desse modo, influir na paixão pela a cidade a partir do afeto e da poesia difundidos - o que vai além dos assuntos culturais e arquitetônicos da cidade.

É notável que, em princípio, as intervenções causem estranhamento naqueles que desconhecem as temáticas e o propósito dessas manifestações. Porém, é cogitável que as intervenções atuem a favor da cidade, provocando nos moradores o desejo de apropriação dos espaços públicos e de humanização entre as pessoas. 
Justificativa: Brasília é uma cidade jovem, construída artificialmente e considerada um marco da arquitetura e urbanismo modernos, além de deter a maior área tombada do mundo e ser a única cidade moderna a ter o título de Patrimônio Cultural da Humanidade (UNESCO). E, junto a isso, Brasília tem intervenções artísticas espalhadas pelo seu território.

A arte da intervenção urbana é uma forma de expressão que pode agregar vários significados tanto para o artista quanto para quem a vê. Pode ser feita através de adesivos, fotografias, montagens, stencil, lambe-lambe, grafite, máscara - entre outros - e tem o propósito de instigar o receptor, podendo até fazê-lo participar da intervenção. Assim sendo, há visivelmente a busca por comunicação, interação e ação no espaço público com o desígnio de elaborar valores e identidades na sociedade.

Este trabalho tem seu mérito na valorização dessa fala social ao procurar retratar, através do levantamento fotográfico de intervenções que comunicam alguma forma de afeto, e da análise de algumas delas, um olhar mais humano e fraterno que as intervenções urbanas podem proporcionar em uma cidade tão movimentada como Brasília. Através do levantamento e da análise dessas imagens é possível ilustrar uma faceta humanitária pela qual os habitantes se sintam donos efetivos da cidade e lutem a favor dela.

É possível ajudar a transformar positivamente a cidade através de suas artes urbanas e fazer com que ela seja referência, afinal, Brasília tem muito a oferecer às pessoas.

Para poder lidar com a caracterização do que é entendido como intervenção visual no espaço público urbano e, também, para delimitar a compreensão da noção de afeto nesse âmbito, procurou-se estruturar conhecimentos básicos sobre espaço público (Habermas), o meio como a mensagem e como uma extensão humana (Mcluhan), a noção de "em casa" x a noção de "não-lugar" (Augé), a visão dos habitantes da cidade como "consumidores do espaço" (Montane), a comunicação como essência humana a partir de Bordenave. Além dessa base teórica, utilizou-se o viés do dispositivo metodológico da semiótica peirceana (Santaella) e o raciocínio de Foucault, via procedimentos de controle dos discursos para, além das redes de sentidos possibilitadas, cogitar também as potenciais rupturas disponibilizadas nas iniciativas em análise. Este é igualmente um ponto de partida: há um estranhamento ocorrendo. Há mensagens procurando a confraternização, o foco no todo, a 
interação real. São as mensagens pela e pela cidade. O agir na cidade e a favor da cidade caracteriza essa ação de interferência. "[...] a intervenção-interação se dá na forma de ação que deforma, modifica e altera, produzindo novos significados pela relação signo-objeto-interpretante no encontro com a heterogeneidade" (RUSSI, 2013, p.51). Tal afirmação elucida o conceito de interferir, alterar e modificar o espaço em que vivemos configurando-o como singular para os transeuntes e heterogêneo para a arquitetura anteriormente planejada. Porém o que torna esse fenômeno intrigante é que essa heterogeneidade produzida pela interferência se torna sinal de identificação daquele local pelos moradores e passantes e, assim, estimula reconhecimento, vínculo, afeto.

\section{b) OBJETIVOS}

Objetivo geral: Este trabalho tem como objetivo resgatar e catalogar um olhar mais humano através de intervenções urbanas. Pretende identificar como intervenções urbanas realizadas em Brasília podem atuar a favor da humanização da cidade. Partiu-se da suposição de que é possível criar um clima de afeto, interação e humanização entre as pessoas manifestando-se de forma poética e provocadora de reflexões no espaço público. Logo, pretende-se compreender como Brasília pode ser mais humana a partir das intervenções visuais, agregando para a realidade dos moradores a ideia de que essas mensagens pela cidade são manifestações positivas que trazem para a cidade mais arte, beleza; e para as pessoas, uma maior identificação e vínculo com o lugar em que moram.

Objetivos específicos: Realizar um mapeamento das intervenções nas passarelas subterrâneas ${ }^{2}$ da Asa Sul que se enquadram nos critérios do projeto.

Relacionar as mensagens expostas com a caracterização da cidade e detectar os artifícios que comunicam algum tipo de afeto, interpessoal ou para com a cidade.

\section{c) REFERENCIAL TEÓRICO}

O ser humano tem como essencial a vivência em grupo e a necessidade de compartilhar, dialogar e trocar experiências com seus semelhantes, o que pode ser

2 
detectado desde os registros dos homens primitivos nas cavernas até os tweets contemporâneos. O ser humano é essencialmente comunicativo. Bordenave (1982) situa a comunicação como inerente à própria vida. Segundo o autor, "a comunicação evoluiu de uma pequena semente - a associação inicial entre um signo e um objeto - para formar linguagens e inventar meios que vencessem o tempo e a distância." (BORDENAVE. 1982, p. 14.), ou seja, a comunicação mostra-se aqui como uma conexão. E os seres humanos estão super conectados, ainda mais com o advento da internet.

Entretanto, quanto ao objeto em questão neste projeto - a manifestação de mensagens pela e pela cidade de Brasília -, apresenta-se adequado o resgate da definição feita por Fiske - "interação social através de mensagens" (1990, p. 1 apud SANTAELLA. 2001, p. 17) - devido à natureza multidisciplinar da comunicação. Santaella remete a várias alternativas de relações comunicativas, sendo a que caracteriza o objeto deste estudo uma relação comunicativa complementar, visto que "o comportamento de um serve como estímulo para o comportamento complementar do outro". (SANTAELLA. 2001, p. 22). Assim, observar a implementação de mensagens pela cidade e o que as compõe para desencadear reações reflexivas e de afeto para com o meio e com os outros - isto é, como essas mensagens podem também atuar pela cidade, em seu favor -, constitui propósito pertinente ao âmbito da comunicação. É via diferentes formatos de comunicação que os padrões de vida da cultura de indivíduos são transmitidos para que ele aprenda a ser um membro de sua sociedade, isto é, é pela comunicação que uma pessoa adota as suas crenças, valores, hábitos e modos de pensamento. (BORDENAVE. 1982).

As mensagens, independente de sua natureza, podem ser compreendidas como formas de marcar, de expressar e de redefinir o cenário pela ação contínua do signo nas suas condições de produção e reconhecimento (RUSSI. 2013). Sendo assim a linguagem por si só já é um tipo de interferência no convívio social, e quando utilizam dela para modificar algo ou afetar o meio em que vivemos, criam-se contextos comunicacionais, ás vezes, tão específicos que quem não participa do grupo não consegue compreender. Russi explora tal compreensão em "o mundo das pichações está constantemente propondo relações a partir de outras manifestações 
e justapõe eventos narrativos que muitas vezes não contam com nexos explícitos." (RUSSI. 2013, p.46).

É possível estabelecer relação com a afirmação de Russi (2013) de que as pichações, entendidas no Brasil como não-arte, demarcam território e apresentam uma linguagem exclusiva de um grupo. Porém os graffiti, aqui com o conceito brasileiro de desenho-arte, criam uma linguagem no espaço urbano que instiga a saber o porquê de se ter feito aquela interferência, e essa reflexão sobre a mensagem aliada ao meio em que ela está inserida podem promover a agregação de valor ao ambiente em que elas estão. Logo, o efeito pode desenhar-se como estímulo de afeto e vínculo.

A linguagem é compreendida como o espaço das possibilidade comunicativas que vão caracterizar as situações e cenários em que acontecem, por isso é nos muros que se delimitam interno e externo ao mesmo tempo em que se transcendem os confins das paredes pelo ato de leitura. (RUSSI. 2013, p.49).

Ou seja, a partir da percepção do signo as intervenções se tornam mensagens que comunicam algo a alguém. As mensagens pela cidade demarcam e ocupam o espaço público urbano e o transcendem na medida do acontecimento comunicativo.

Sua inserção espacial pode capacitá-las a influenciar no sentido do estranhamento e da mudança de visão sobre diversos aspectos políticos, culturais e sociais divergentes do que a grande mídia divulga ou que outros meios propagam. Isso caracteriza-se facilmente perceptível e como indicador da provável busca por espaço para comunicação. Russi (2013) enfatiza tal entendimento ao lembrar da possibilidade de se

[...] refletir sobre a tensão decorrente da falta de espaço para "dizer" como sendo uma das características que mais apropriadamente definem as pichações - expressão dos que não têm espaço de fala social ou midiática, optam por espaços não oficiais/convencionais. (RUSSI. 2013, p. 48).

As intervenções em muros, paredes, chão da cidade caracterizam recados e podem ser percebidas como uma manifestação artística, uma expressão poética ou militante já que possuem no seu âmago a provocação, o despertar nos passantes à 
reflexão sobre sua atuação no círculo social em que vivem e "podem interferir na vida das pessoas, como de fato determinam seus destinos, moldam sua percepção, impõem-lhes restrições, definem recortes e janelas para o seu mundo." (BAITELLO JR. 2005, p. 42)

É necessário cogitar que, neste estudo, a afirmação de Mcluhan (2007), de que o meio é a mensagem, configura-se de modo muito concreto. A própria cidade é aqui o meio, duplamente. Vivemos nesse meio e o usamos para registrar manifestações, falas. A cidade é a mensagem, agora alterada graças a intervenções de seus habitantes, intencionais, inseridas no meio em que os outros transitam, vivem. $O$ cidadão conecta-se à cidade, um passa a ser extensão do outro. O autor das intervenções quer falar com os habitantes da cidade. Para tanto, projeta-se nas paredes das passarelas, por exemplo. E o transeunte, ao identificar-se, também ali se reconhece e projeta, portanto. Deste modo, o próprio espaço público passa a constituir extensão dos seus ocupantes, dos habitantes da cidade. Logo, é coerente afirmar que as mensagens pela cidade chamam à consciência do pertencimento, ao vínculo com o ambiente pelo qual se transita.

O espaço público é um conceito abordado por Habermas (1987) como lugar de desenvolvimento de opiniões e, por isso, um lugar democrático para a comunicação, de uso comum e de posse de todas as pessoas. Entretanto, talvez as novas formas de produção e funções sociais tenham interferido no movimento das cidades, criando uma nova percepção do que é público e privado, de tal modo que essa esfera contemporaneamente é vivenciada como privada.

Bauman (2001) explica como essa mudança ocorreu na esfera social. A sociedade classificada por ele como líquida, fluida, é considerada instável, e o individuo produtor passa ao papel de consumidor, contrário em relação à crítica e extremamente agitado, não aceitando o concreto, o "ficar parado". Tudo 'transitório, efêmero, de vínculos frágeis, dissolúveis e adaptáveis ou reconfiguráveis. Segundo o autor, a cidadania e o público têm ligação direta. O que ocorre quando o privado coloniza o público é que os cidadãos são substituídos por indivíduos, os quais, em geral, não se importam com o interesse público. Há, entretanto, uma pequena parcela de indivíduos que modifica essa dinâmica, reapropriando-se de ferramentas 
perdidas da cidadania. É nessa ruptura e reconfiguração que reside a possibilidade de reestabelecer o equilíbrio social e de poder oferecer doses de estabilidade para a sociedade fluída. (AGAPITO. 2013)

O não-vínculo, o não-pertencimento são noções cada vez mais facilmente observáveis. Pessoas sentam-se na grama, debaixo de mangueiras, mas concentram-se em smartphones, mergulham nas redes sociais virtuais e parecem evitar o que acontece de real ao seu redor. Assim não vivem realmente o ambiente público, apenas transitam por ele e não deixam sua marca.

Um conceito que situa esse tipo de relação a partir da própria característica do ambiente é o conceito de não-lugar, difundido pelo etnólogo e sociólogo Marc Augé (1994). Para ele, os espaços de passagem, onde costumam acontecer muitas das intervenções visuais em foco no presente projeto, funcionam como locais desprovidos de essência, tais como aeroportos, hoteis, shopping centers. Em ambientes assim, não importa a localidade, a língua oficial, a cultura do lugar. (DAMIÃO. 2013)

Se um lugar pode se definir como identitário, relacional e histórico, um espaço que não se pode definir nem como identitário, nem como relacional, nem como histórico definirá um não-lugar. O lugar e o não-lugar se encontram: "o primeiro nunca é completamente apagado e o segundo nunca se realiza totalmente." (AUGÉ. 1994, p. 74)

As passarelas subterrâneas do Plano Piloto seriam todas muito similares Porém, com as intervenções nelas inseridas, cada uma tem cara e mensagem própria. Ocorre a transformação do não-lugar em um espaço de provocação e potencial identificação, um espaço "em casa".

Para os planejadores urbanos Jan Gehl e Lars Gemzoe (2002), as cidades sempre foram um espaço público de encontro, comércio e de circulação. Contudo, a revolução industrial e a criação dos automóveis propiciaram a mudança radical que vemos nas cidades atualmente. O automóvel modificou a dinâmica das cidades, as pessoas pararam de transitar em espaços e ter experiências sociais neles, e 
iniciaram um processo de apenas "passar" pelo espaço, sem criar vínculos ou vivenciar alguma percepção dele.

Brasília é a capital de nosso país, o Brasil. É uma cidade nova, construída artificialmente, ou seja, ela foi construída para as pessoas virem para cá (e não no processo normal, em que pessoas se juntam em determinado lugar e acabam construindo uma cidade). Foi planejada para um número máximo de habitantes em torno de 500 mil, mas hoje o Distrito Federal, de acordo com o censo de 2010 do IBGE, possui em torno de 2.570.160 habitantes.

O eixo monumental é a espinha dorsal da cidade, onde os poderes e monumentos se concentram e, contraditoriamente a outras cidades, a Praça dos Três Poderes se localiza - na extremidade e não no centro. A Praça de Brasília não é estruturadora e ponto de socialização como em outras cidades, função repassada para pontos como o Setor Comercial Sul e a Rodoviária, localizada no ponto de encontro entre os dois eixos. (LAUANDE. 2012) .

A lógica da escala monumental ser representada pela Praça dos Três Poderes retrata a imagem que muitos possuem sobre Brasília, de cidade fria e sem espaços de convívio. Porém, o planejamento da escala residencial reflete a dinâmica, a vida e as atividades da esfera pública. (AGAPITO. 2013)

Visto a partir da semiótica peirceana, as intervenções visuais urbanas seriam signos, que representam algo para alguém criando um referencial para surgirem novas ideias, questionamentos e produzir significações. Então, é possível compreender o motivo de as intervenções terem apelos diferentes, como didático, confrontador, ideológico entre outros. Mensagens pela cidade podem atuar a favor (pela) da mesma na medida em que afetam os passantes. Segundo SANTAELLA (2002, p. 37), "é só na relação com o interpretante que o signo completa sua ação como signo".

A afirmação de que um material é sentido antes de realmente ser decodificado é defendida por Barthes quando ele analisa o funcionamento da mensagem publicitária, terreno favorável a se compreender como se constitui o processo de construção de significados. O autor revela que aquilo que imediatamente 
percebemos é o segundo significado, o grau conotativo da mensagem; só depois a decodificamos (BARTHES. 2001).

Por isso mesmo, o dispositivo metodológico da Semiótica constitui arsenal adequado para a abordagem dos materiais analisados neste projeto. Para Santaella, "a Semiótica é a ciência que tem por objeto de investigação todas as linguagens possíveis, ou seja, que tem por objetivo o exame dos modos de constituição de todo e qualquer fenômeno como fenômeno de produção de significação e sentido." (1983, p. 13) Assim, analisar como as mensagens pela e pela cidade atuam na interpelação dos transeuntes, dos habitantes desse espaço, configura-se em leitura de significações possíveis e que aparentemente funcionam como provocadoras de vínculo e envolvimento com as questões do coletivo, marca registrada do espaço urbano. Para tanto, buscou-se o amparo da análise nas tricotomias que classificam o acontecimento sígnico na percepção do representante em si mesmo (quali-signo, sin-signo e legi-signo) e em sua relação com seu referente (ícones, índices e símbolos). Deste modo, foi possível perceber recorrências, dominâncias, sejam elas cromáticas, figurativas, de técnica empregada, de noções e pensamentos expressos. A partir da análise desses elementos se estabeleceu a relação com a questão do afeto em relação à cidade.

Complementar a tal abordagem e valorizando o situar contextual, o olhar com foco no aspecto ideológico, a Análise do Discurso de vertente francesa, disponibilizou funcional raciocínio a partir dos procedimentos de controle dos discursos apresentados por Foucault, em "A ordem do Discurso", como viés metodológico na análise de comunicações. Nessa perspectiva,

a produção do discurso é ao mesmo tempo controlada, selecionada, organizada e redistribuída por certo número de procedimentos que têm por função conjurar seus poderes e perigos, dominar seu acontecimento aleatório, esquivar sua pesada e temível materialidade. (FOUCAULT, 1996, p. 8-9).

Portanto, ações comunicacionais transformam o espaço e o tornam nossa casa, produzem significação para um local que antes não chamava atenção, ou seja, estimulam a noção de pertencimento ao local, de vínculo. Desse modo, "o urbano 
configura-se por uma dinâmica recursiva, caracterizada pelas ações sociais dos sujeitos que lhes dão sentido." (RUSSI. 2013, p.54)

\section{d) METODOLOGIA}

A presente pesquisa tem cunho exploratório, pois "tem como principal finalidade desenvolver, esclarecer e modificar conceitos e ideias, tendo em vista a formulação de problemas mais precisos ou hipóteses pesquisáveis para estudos posteriores" (GIL. 1991, p. 46). Portanto, planejou-se captar melhor a realidade que nos cerca e contribuir, via estudo, para um olhar mais apurado e qualitativo em relação à mesma.

Como um todo, este estudo adotou um prisma qualitativo, isto é, há um grau de participação do pesquisador, seja no levantamento fotográfico, na análise das imagens selecionadas e, inclusive, na abordagem dos transeuntes para a aplicação do questionário - este com um viés algo quantitativo.

A pesquisa qualitativa, segundo Arilda Godoy é "um fenômeno que melhor se faz compreender o contexto do qual faz parte o objeto estudado e podendo ser analisado de uma forma integrada." (GODOY)3. Já a abordagem quantitativa, segundo Valter Vieira e Fernando Tibola (2016), "procura quantificar os dados e aplica-se alguma forma da análise estatística para tratamento dos dados."

Para embasar toda a percepção das intervenções visuais urbanas e sua atuação no ambiente público, fez-se necessário o estudo bibliográfico. Este foi sucedido por etapa descritiva, aqui compreendida como "aquelas que têm por objetivo estudar as características de um grupo" (GIL.2002, p. 42) de imagens selecionadas com identificação das características predominantes, semelhanças e diferenças mais evidentes. As imagens foram analisadas a partir do pressuposto das escolhas que as compõem, aplicando-se as categorias das tricotomias peirceanas quanto à condição do representante em si e da relação deste com seu referente. Acentuando

3 GODOY, Arilda Schmidt. Pesquisa Qualitativa: Tipos Fundamentais. Disponível: http://www.scielo.br/pdf/rae/v35n3/a04v35n3.pdf. Acesso em: 26/07/2016 
um olhar mais contextualizado, a análise foi complementada com a abordagem foucaultiana sobre procedimentos de controle dos discursos (FOUCAULT, 1996).

Além disso, a fim de certificar as percepções elaboradas no estudo, realizou-se 40 entrevistas estruturadas ${ }^{4}$ em 10 perguntas, das quais 7 eram fechadas e de múltipla escolha, e 3 eram qualitativas. O propósito foi, primeiro, conhecer o perfil dos entrevistados, verificando gênero, idade, escolaridade, e depois afunilando para o projeto, detectando o motivo e a frequência de trânsito pelo local e se já haviam percebido as mensagens nas passagens, a fim de conhecer o que pensam, sentem e como percebem as intervenções das passagens subterrâneas da Asa Sul. Assim, a finalidade da pesquisa de campo via questionário estruturado em questões mistas (fechadas e abertas) foi a de detectar o que manifestam sobre as intervenções, o que elas transmitem e se as mensagens propagadas articulam a humanização da cidade e dos moradores através do afeto difundido nas intervenções.

Ainda foi realizada uma segunda etapa da pesquisa de campo, desta vez on-line, via a ferramenta "Formas" do Google. Nesta aplicou-se um filtro para selecionar quem realmente iria responder o questionário, de modo que a primeira pergunta do questionário apontava se efetivamente ocorria o uso das passarelas subterrâneas da Asa Sul pelo respondente. Logo, só foram considerados válidos os questionários respondidos pelos frequentadores do espaço em questão, ou seja 27.

Assim, o estudo pode analisar se e como mensagens expostas pela cidade podem atuar pela cidade e por sua humanização.

\section{d) RESULTADOS E DISCUSSÃO}

Após o levantamento fotográfico das intervenções visuais foi feito um recorte no conteúdo que mobilizasse noções de afetos. Assim ficaram registradas cerca de 250 intervenções visuais nas passarelas subterrâneas na Asa Sul. Estas foram classificadas quanto à técnica utilizada, presença de texto verbal, trabalho estilizado e autoral ou espontâneo e anônimo. A partir daí selecionou-se 35 imagens de técnica e quadra variadas para aplicar as análises da primeira e segunda tricotomias

4 Formulário disponível nos Apêndices. 
peirceanas, a fim de estabelecer seu funcionamento enquanto estrutura de sentido e significado que produzem, e, depois, verificar via raciocínio foucaultiano sobre procedimentos de controle dos discursos as noções ideológicas que possibilitam

A seguir, exemplifica-se 0 procedimento de análise com 7 imagens e a sistematização via tricotomias peirceanas. O restante das análises está nos apêndices deste trabalho.

\section{Análise peirceana das intervenções visuais urbanas:}

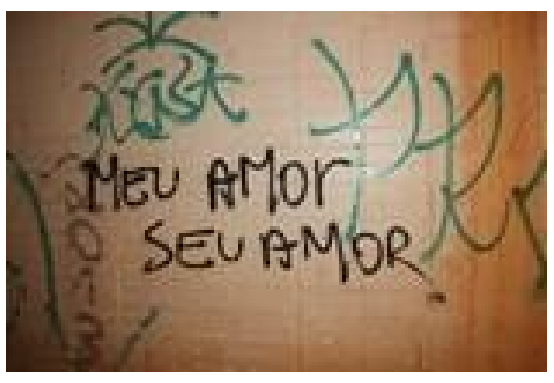

Figura 1 Quadra 116, Asa Sul

Autora: a pesquisadora

\begin{tabular}{|c|c|}
\hline Primeira Tricotomia & Segunda Tricotomia \\
\hline $\begin{array}{l}\text { Quali-signo: riscos } \\
\text { preto }\end{array}$ & Ícones: ------------- \\
\hline $\begin{array}{lr}\text { Sin-signo: frase } & \text { em } \\
\text { preto, em } & \text { língua } \\
\text { portuguesa, } & \text { fundo } \\
\text { branco } & \\
\end{array}$ & Índice: técnica do spray, livre \\
\hline $\begin{array}{l}\text { Legi-signo: frase escrita } \\
\text { à mão com spray na } \\
\text { cor preta: "Meu amor } \\
\text { seu amor". }\end{array}$ & $\begin{array}{l}\text { Símbolos: a frase na língua portuguesa, escrita de forma } \\
\text { livre e manual = expressão individual; letras em caixa alta } \\
\text { = importância; cor preta = padrão, afirmação, seriedade; } \\
\text { repetição da palavra amor, = foco da } \\
\text { comunicação;pronomes possessivos meu e teu = nosso. }\end{array}$ \\
\hline
\end{tabular}




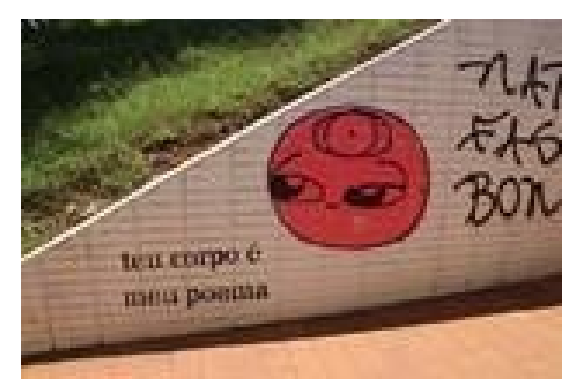

Figura 2 Quadra 116, Asa Sul

Autora: a pesquisadora

Gurulino vermelho

\begin{tabular}{|c|c|}
\hline Primeira Tricotomia & Segunda Tricotomia \\
\hline $\begin{array}{l}\text { Quali-signo:cores } \\
\text { vermelha e preto }\end{array}$ & Ícone: cabeça, rosto, olhos, terceiro olho \\
\hline $\begin{array}{l}\text { Sin-signo: desenho de } \\
\text { cabeça/rosto } \\
\text { humanóide com } \\
\text { terceiro olho, na cor } \\
\text { vermelha com } \\
\text { contornos em preto }\end{array}$ & Índice: técnica do spray, à mão livre \\
\hline $\begin{array}{l}\text { Legi-signo: o conhecido } \\
\text { personagem brasiliense } \\
\text { Gurulino }\end{array}$ & $\begin{array}{l}\text { Símbolo: o conhecido personagem Gurulino pintado na } \\
\text { cor vermelha = atenção; olhos pensativos = reflexão, } \\
\text { questionamento; terceiro olho = capacidade de maior } \\
\text { visão, sabedoria. }\end{array}$ \\
\hline
\end{tabular}

Frase "teu corpo é meu poema"

\begin{tabular}{|l|l|}
\hline Primeira Tricotomia & Segunda Tricotomia \\
\hline Quali-signo: cor preta & Ícone: -------- \\
\hline $\begin{array}{l}\text { Sin-signo: frase na } \\
\text { língua portuguesa, em } \\
\text { preto }\end{array}$ & Índice: técnica do stencil \\
\hline $\begin{array}{l}\text { Legi-signo: a frase "teu } \\
\text { corpo é meu poema" }\end{array}$ & $\begin{array}{l}\text { Símbolo: frase = direcionamento da comunicação, } \\
\text { clareza; tipia padrão = foco no conteúo; cor preta } \\
\text { padrão, seriedade; stencil = repetição, intenção } \\
\text { comunicativa de maior alcance; pronomes possessivos } \\
\text { meu e teu = posse; corpo/poema = abstração, }\end{array}$ \\
\hline
\end{tabular}




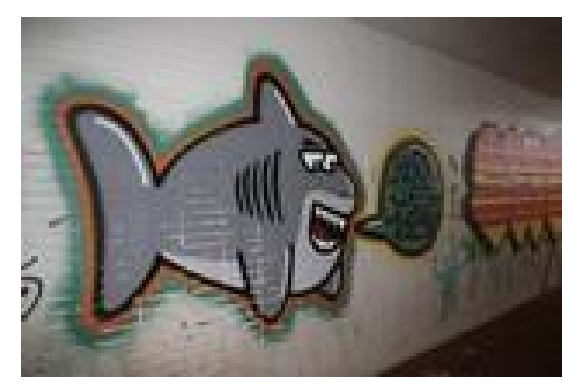

Figura 3 Quadra 116, Asa Sul

Autora: a pesquisadora

\begin{tabular}{|l|l|}
\hline Primeira Tricotomia & Segunda Tricotomia \\
\hline $\begin{array}{l}\text { Quali-signo: Mancha } \\
\text { cinza Ícone: tubarão }\end{array}$ & \\
\hline Sin-signo: desenho Índice: desenho produzido com spray. \\
cinza em fundo branco \\
e balão verde
\end{tabular}

\section{Dî FLORES} A0S vivos

Figura 4 Quadra 114, Asa Sul

Autora: a pesquisadora

A frase "Dê flores aos vivos" 


\begin{tabular}{|l|l|}
\hline Primeira Tricotomia & Segunda Tricotomia \\
\hline Quali-signo: cor preta & Ícone: ------------- \\
\hline $\begin{array}{l}\text { Sin-signo: frase na } \\
\text { língua portuguesa }\end{array}$ & Índice: escrita via stencil \\
\hline $\begin{array}{l}\text { Legi-signo: frase "Dê } \\
\text { flores aos vivos" }\end{array}$ & $\begin{array}{l}\text { Símbolo: frase = clareza na comunicação; cor preta = } \\
\text { padrão, seriedade; caixa alta = importância; stencil = } \\
\text { repetição, intenção comunicativa de maior alcance; uso } \\
\text { do imperativo = ordem, conselho, indução à ação; "flores } \\
\text { aos vivos" = contraposição ao costume de dar flores aos } \\
\text { mortos, alerta à necessidade de expressar carinho }\end{array}$ \\
\hline
\end{tabular}

O desenho de uma flor

\begin{tabular}{|l|l|}
\hline Primeira Tricotomia & Segunda Tricotomia \\
\hline $\begin{array}{l}\text { Quali-signo: traços em } \\
\text { verde }\end{array}$ & Ícone: flor \\
\hline Sin-signo: desenho & Índice: desenho à mão livre com spray \\
\hline Legi-signo: flor verde & $\begin{array}{l}\text { Símbolo: desenho = produção; flor = natureza, vida, } \\
\text { delicadeza, gentileza; verde = natureza, vida, leveza }\end{array}$ \\
\hline
\end{tabular}

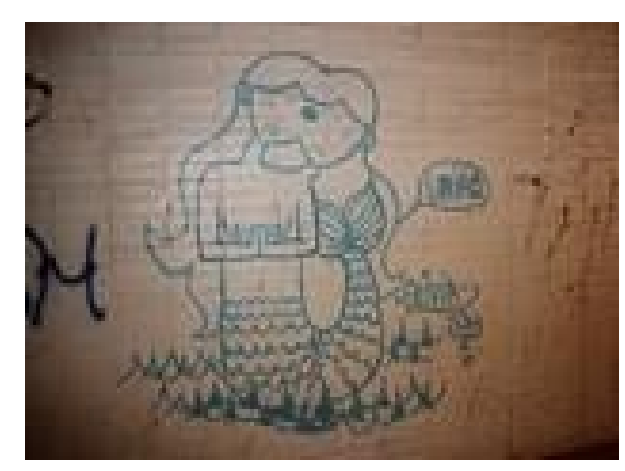

Figura 5 Quadra 114, Asa Sul

Autora: a pesquisadora

\begin{tabular}{|l|l|}
\hline Primeira Tricotomia & Segunda Tricotomia \\
\hline $\begin{array}{l}\text { Quali-signo: traços } \\
\text { azuis }\end{array}$ & Ícone: sereia de duas cabeças, cabelos longos, mar \\
\hline $\begin{array}{l}\text { Sin-signo: desenho de } \\
\text { figura feminina }\end{array}$ & Índice: desenho feito com spray e livre traço \\
\hline $\begin{array}{l}\text { Legi-signo: Desenho de } \\
\text { uma sereia com duas } \\
\text { cabeças. }\end{array}$ & $\begin{array}{l}\text { Símbolo: desenho = produção; sereia = ser feminino } \\
\text { anomalia, maior racionalidade; cor azul = marítimo, }\end{array}$ \\
\hline
\end{tabular}




\begin{tabular}{|l|l|}
\hline & $\begin{array}{l}\text { tranquilidade, razão; mãos juntas em frente ao peito }= \\
\text { reverência, respeito }\end{array}$ \\
\hline
\end{tabular}

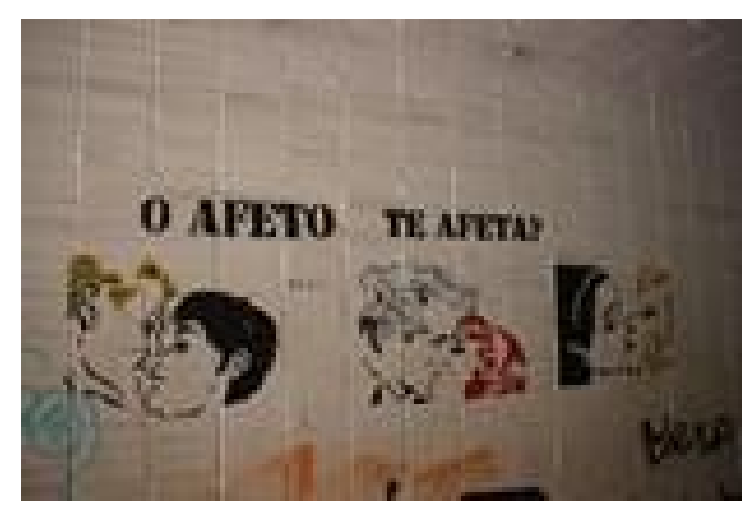

Figura 6 Quadra 114, Asa Sul

Autora: a pesquisadora

\begin{tabular}{|l|l|}
\hline Primeira Tricotomia & Segunda Tricotomia \\
\hline $\begin{array}{l}\text { Quali-signo: manchas } \\
\text { coloridas, preto }\end{array}$ & $\begin{array}{l}\text { Ícones: cabelo, rostos humanos, de homens e de } \\
\text { mulheres, beijos }\end{array}$ \\
\hline $\begin{array}{l}\text { Sin-signo: desenho } \\
\text { estilizado de 3 pares de } \\
\text { rostos se beijando e } \\
\text { uma pergunta }\end{array}$ & Índice: técnica do stencil \\
\hline $\begin{array}{l}\text { Legi-signo: casais } \\
\text { homo e heterossexuais } \\
\text { se beijando e a } \\
\text { pergunta "O afeto te } \\
\text { afeta?" }\end{array}$ & $\begin{array}{l}\text { Símbolo: stencil = repetição, intenção comunicativa de } \\
\text { maior alcance; cores preto, vermelho e amarelo = definição, seriedade e energia; rostos = } \\
\text { identidade; beijo = afeto; 3 casais = diversidade, opções; } \\
\text { desenho = produção, simulação; pergunta = interpelação, } \\
\text { questionamento, reflexão; frase em preto = seriedade, } \\
\text { foco; jogo de palavras afeto/afeta = reafirmação, } \\
\text { indicação; pronome "te" = proximidade, direcionamento, } \\
\text { intimidade, vínculo }\end{array}$ \\
\hline
\end{tabular}




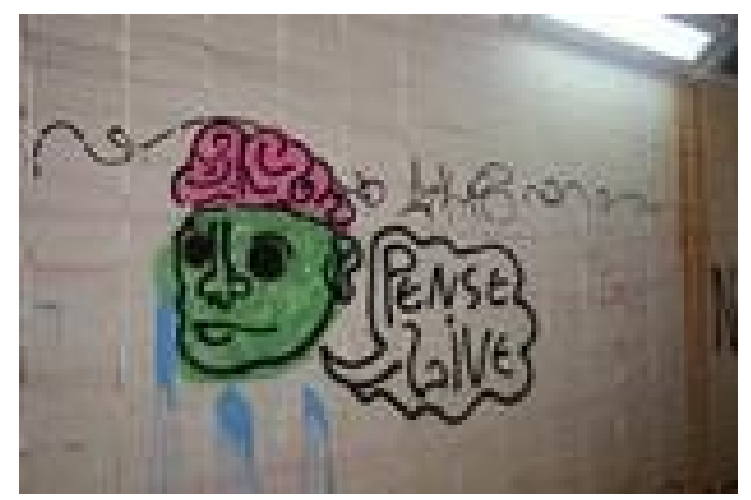

Figura 7 Quadra 109, Asa Sul

Autora: a pesquisadora

\begin{tabular}{|c|c|}
\hline Primeira Tricotomia & Segunda Tricotomia \\
\hline $\begin{array}{l}\text { Quali-signo: mancha } \\
\text { em verde, rosa e preto }\end{array}$ & $\begin{array}{l}\text { Ícones: cabeça humana, cérebro à mostra, olhos, nariz, } \\
\text { boca vazados e orelha }\end{array}$ \\
\hline $\begin{array}{l}\text { Sin-signo: desenho de } \\
\text { cabeça humana em } \\
\text { verde e balão de fala } \\
\text { ao lado. }\end{array}$ & Índice: desenho e escrita à mão livre, feitos com spray \\
\hline $\begin{array}{l}\text { Legi-signo: Desenho de } \\
\text { uma cabeça humana } \\
\text { com rosto verde e } \\
\text { cérebro rosa à mostra } \\
\text { com balão de fala onde } \\
\text { se lê "Pense live" }\end{array}$ & $\begin{array}{l}\text { Símbolos: desenho = produção, simulação; cabeça } \\
\text { humana = identificação; rosto em cor verde = anomalia, } \\
\text { diferencial; a cor verde = mudança, evolução; cérebro à } \\
\text { mostra = anomalia, evidência, pensamento; cerébro na } \\
\text { cor rosa = vivo, em funcionamento; olhos vazados = sem } \\
\text { visão exterior, visão interior; balão de conversa = } \\
\text { propósito comunicativo, manifestação, diálogo; a frase } \\
\text { "Pense live" = conselho, ordem; na cor preta = padrão, } \\
\text { seriedade; em caixa alta = importância; "pense" em } \\
\text { língua portuguesa = clareza; "live" em língua inglesa = } \\
\text { despojamento, diferenciação, juventude, identificação }\end{array}$ \\
\hline
\end{tabular}

Ao sistematizar o que se revela via análise peirceana, pode-se destacar a predominância do recurso linguístico, que sugere maior preocupação com a clareza da informação. Também há mais imagens produzidas à mão livre, o que indica a espontaneidade da ação e o maior peso na vontade de dizer algo em detrimento da exposição artística em si. As cores são fortes, para serem percebidas, além de 
estarem coerentes com o foco maior na comunicação da fala do que na produção artística. As figuras humanóides são altamente predominantes ${ }^{5}$, promovendo identificação e, assim, trabalhando a eficácia comunicativa, o propósito de atingir o outro. Além da spray à mão livre, a técnica do stencil marca presença, valorizando o propósito comunicativo, já que se baseia na reprodução seriada, na repetição e maior alcance via distribuição da mesma mensagem em vários pontos da cidade. $\mathrm{O}$ universo simbólico caracteriza-se pela conotação de seriedade e informação, via a dominância da cor preta, que é padrão e coloca o foco no conteúdo e não na escolha cromática em si; as demais cores são coerentes com o âmbito conotativo da imagem, seja alerta, vida, diversidade, reflexão. As figuras remetem ao viver, ao repensar condutas e modificar percepções. A noção de afeto aparece claramente algumas vezes e, em outras, sugerida via outras noções como amor e vida.

\section{- Procedimentos de controle dos discursos - AD foucaultiana:}

Ao se analisar o conjunto observado sob a perspectiva dos procedimentos de controle dos discursos (a partir de Foucault, em "A ordem do discurso), ou seja, cogitando o peso das escolhas feitas na exposição das mensagens em detrimento de outras opções, recorresse às categorias enunciadas pelo autor - palavra proibida, segregação da loucura, vontade de verdade, comentário e a figura autoral.

A respeito da palavra proibida e a segregação da loucura, ou seja, a escolha de outras formas de dizer o que se queria e o que isso significaria, observou-se que as manifestações verbais, em geral, ocupam maior espaço e sinalizam, pressupostamente, maior pressa e preocupação com a segurança ou o local que o trabalho é realizado. Permitem também maior relação com a clareza da comunicação (em detrimento das figuras, que possibilitam mais amplo leque interpretativo), muitas vezes amparam-se em noções poéticas, ditos populares ou versos de samba, facilitando o reconhecimento, a identificação, a aceitação da fala e, até mesmo, sua reprodução.

5 Diferente do que se percebeu na análise das intervenções visuais urbanas das passarelas da Asa Norte - Relatório PIC 2015 -, em que havia maior cunho artístico e grande presença de imagens figurativas de animais como corujas e borboletas. 
As mensagens imagéticas, especialmente quando não acompanhadas por uma frase, valorizam mais o aspecto artístico da fala e sua aura conotativa, apresentando-se, provavelmente, com mais apelo à percepção da intervenção. Não são, porém, em sua maior parte, imagens programadas antes ou trabalhadas com esmero, mas sim também fruto de maior espontaneidade e valorização do caráter representativo que guardam e ativam em relação à comunicação. A ênfase estaria, então, em ativar tal associação e não trabalhá-la esteticamente.

Assim, a vontade de verdade seria, marcadamente, o desejo de comunicar, de atingir o outro, de despertar reflexão, de atingi-lo. Tal propósito corrobora a noção da vida em coletividade, que caracteriza o ambiente urbano e colabora para a humanização e promoção de vínculo e afeto. As passarelas guardam a presentificação de habitantes que escolhem ali se expressarem para demarcar aqueles espaços com a busca pelo outro, por comunicar-se, por promover reflexão esta direcionada à vivência humana afetiva, em geral.

A seleção de intervenções analisadas podem funcionar como comentário no sentido de lembrar frases cotidianas ou já conhecidas pelas pessoas como as que são trechos de músicas, ou também aquelas que fazem refletir sobre o amor, as relações humanas, o afeto e tudo que envolve o dia a dia das pessoas. Palavras usadas como amor, afeto, poema, corpo, meu, seu, flores, vivos, feliz, cidade, olhos, enfim relacionadas a situações do cotidiano, promovem associação com o que se vive e abrem o canal comunicativo e de aceitação daquelas falas. Assim, por si só, já trabalham a noção de vínculo, de ligação, de aceitação, logo, de afeto.

Quanto ao procedimento de controle discursivo da figura e papel do autor, este raramente se identifica, são poucas as intervenções assinadas. Novamente é o propósito comunicativo, a ação sobre o outro e seu conteúdo que ganham relevância, e não o fazer artístico. O personagem Gurulino, muito presente em toda a cidade de Brasília, já carrega consigo um caráter diferenciado, de reconhecimento, porém não remetendo ao autor, o que não significa que não ocorra aí um reconhecimento de estilo e conteúdo dessa fala. Mas o foco fica na fala em si, e não no seu autor, Pedro Sangeon. 
Pode-se afirmar, portanto, que a análise discursiva possibilita relacionar ao conjunto de intervenções visuais urbanas analisadas nas passarelas da Asa Sul do Plano Piloto, Brasília, DF, a escolha enfática do viés comunicativo, do intento de atingir o outro na direção da reflexão e do vínculo dentro da coletividade.

\section{Pesquisa de Campo: questionários}

Para complementar a visão elaborada a partir das análises, definiu-se a opção de coletar a impressão de transeuntes dos espaços em foco no estudo quanto à existência e efeito das intervenções visuais urbanas. Assim, foram feitas entrevistas, por meio de questionário estruturado ${ }^{6}$, com usuários das passagens subterrâneas da Asa Sul, Brasília, no mês de julho de $2016^{7}$.

\section{Entrevistas presenciais:}

Inicialmente, realizou-se a aplicação do questionário presencialmente, nas quadras 102 e 106 Sul, e se obteve os seguintes resultados, sendo a primeira parte para caracterização do perfil dos respondentes, e, então, a segunda parte para a verificação da percepção dos respondentes quanto às intervenções visuais nas passarelas:

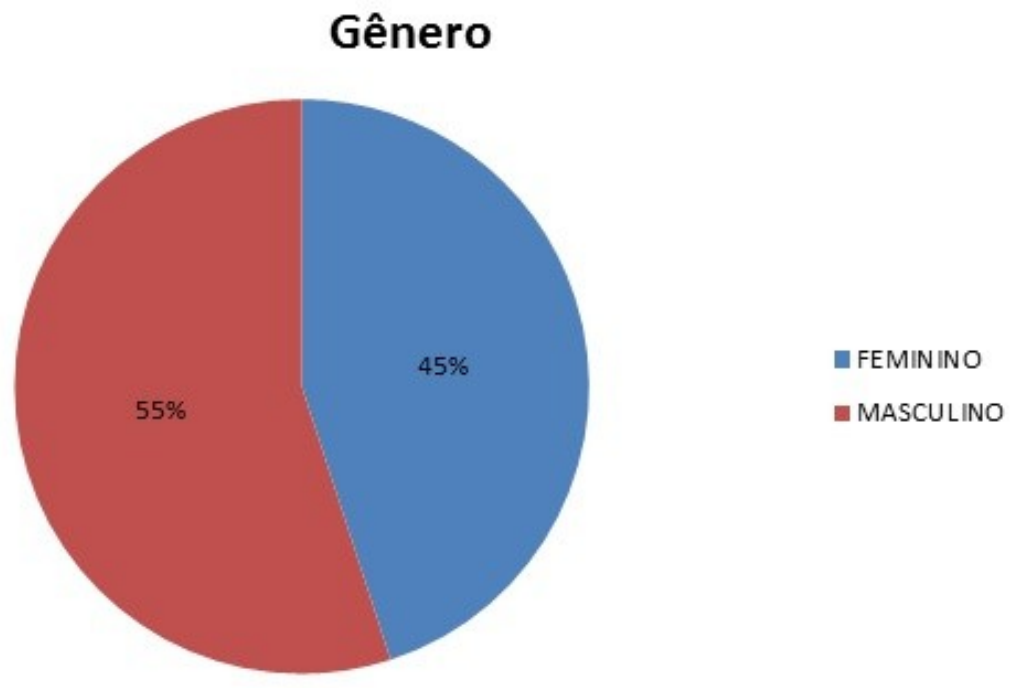

6 O formulário utilizado está nos Apêndices deste trabalho.

7 Originalmente a pesquisa seria aplicada em maio, mas houve atrasado, inclusive por problemas no sistema da Plataforma Brasil, para a submissão ao Comitê de Ética. 
O gênero dos respondentes predominante na pesquisa foi o masculino com 22 respostas, enquanto o feminino teve 18 respostas.

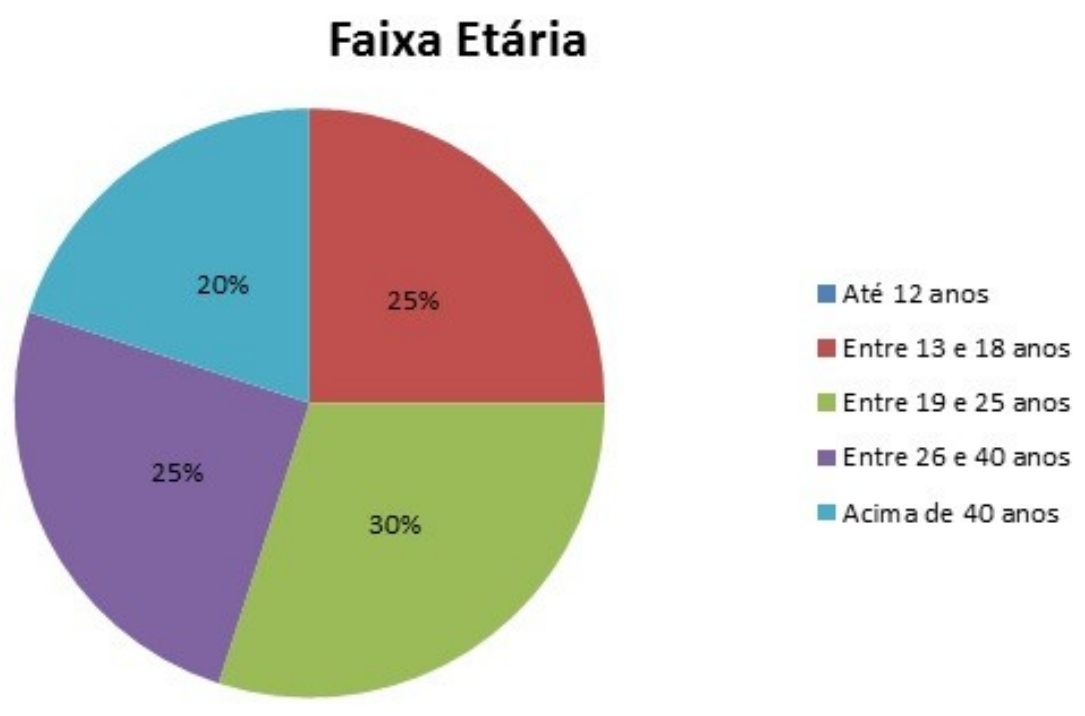

Questão 2 Presencial

A faixa etária predominante na pesquisa foi a de 19 a 25 anos com 12 respostas, seguido de 13 a 18 anos e 26 a 40 anos, ambos com 10 respondentes. Ou seja, a maioria dos respondentes era jovem.

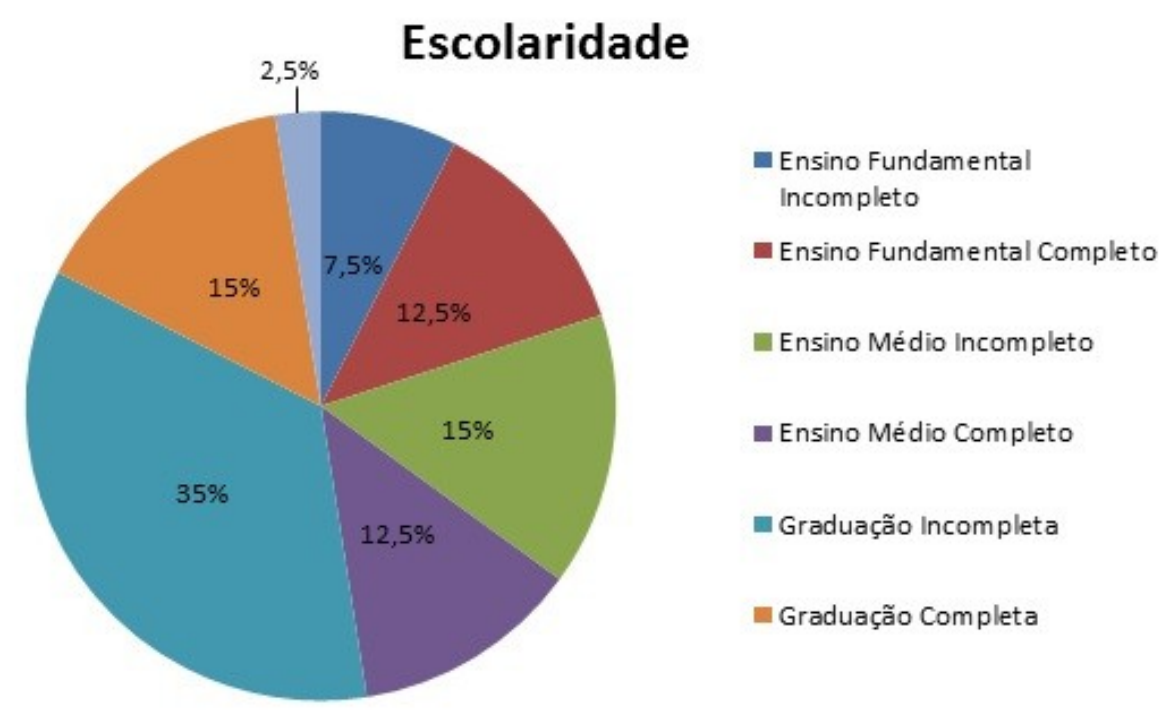

Questão 3 Presencial

Quanto à escolaridade, 14 entrevistados afirmaram terem graduação incompleta, seguido de ensino médio incompleto e graduação completa - ambos com 6 
respondentes. 5 respondentes afirmaram ter ensino médio completo, e o mesmo número, ensino fundamental completo. O perfil escolar é coerente com o de faixa etária, já que os jovens, em princípio, estão em fase de escolarização, universitária ou de ensino médio.

\section{Motivo de transitar pelo local}

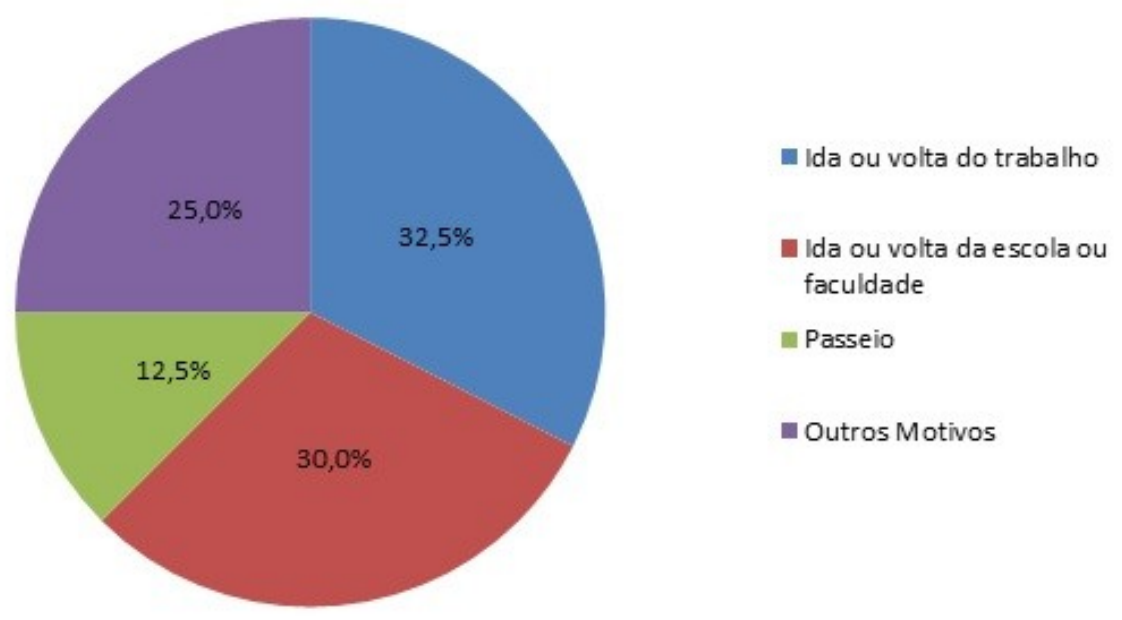

Questão 4 Presencial

O motivo predominante dos transeuntes de usar as passagens subterrâneas é ida ou volta do trabalho, com 13 respostas, seguido de ida ou volta da escola ou faculdade, com 12 respostas. Com relevância também aparece outros motivos e passeio, com 15 respostas os dois juntos. Novamente há compatibilidade com os dados anteriores: jovens estudantes. 


\section{Frequência que passa pelo local}

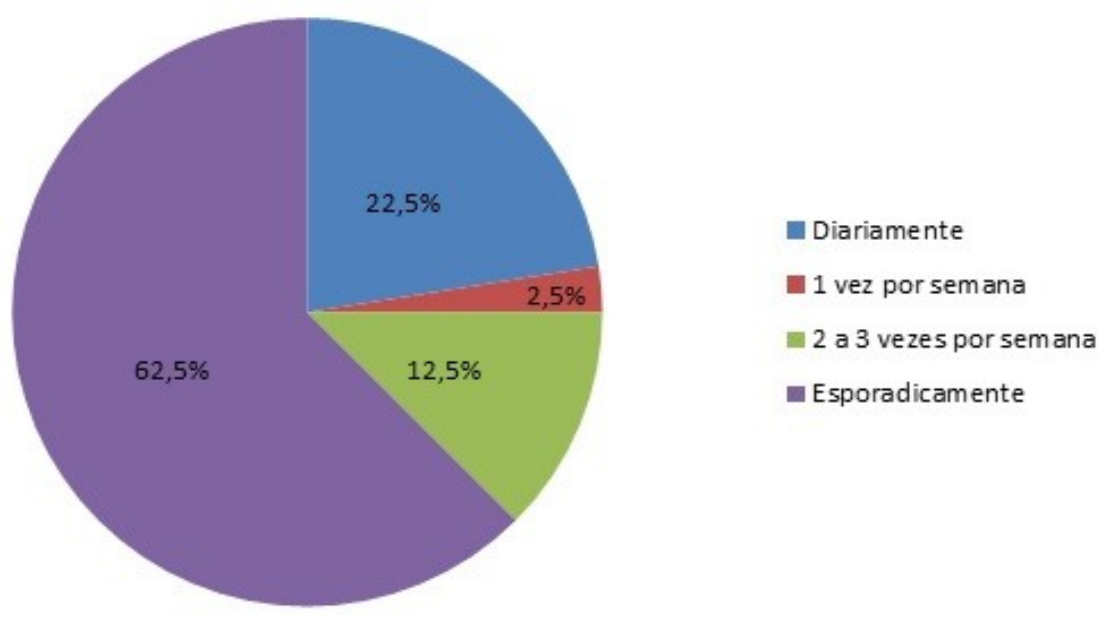

Questão 5 Presencial

A frequência dominante nas resposta foi de vez em quando, com 25 respostas, seguido de diariamente, com 9 respostas. Depois aparecem 2 a 3 vezes por semana com 5 respondentes, e, por último, esporadicamente, com 1 resposta. Aqui talvez se possa estranhar o resultado, imaginando que jovens estudantes devam fazer o percurso escola ou trabalho mais rotineiramente. Provavelmente a variável referente a meios de transporte e auxílio dos pais, quanto a isso, impacta esse item, especialmente se tratando da área do Plano Piloto, Brasília. Por outro lado, considera-se o alto índice referente à "esporadicamente" vantajoso à observação, no sentido de diminuir a probabilidade da automatização do percurso e da consequente anulação ou diminuição da percepção consciente do ambiente ao redor. 


\section{Já percebera as intervenções?}

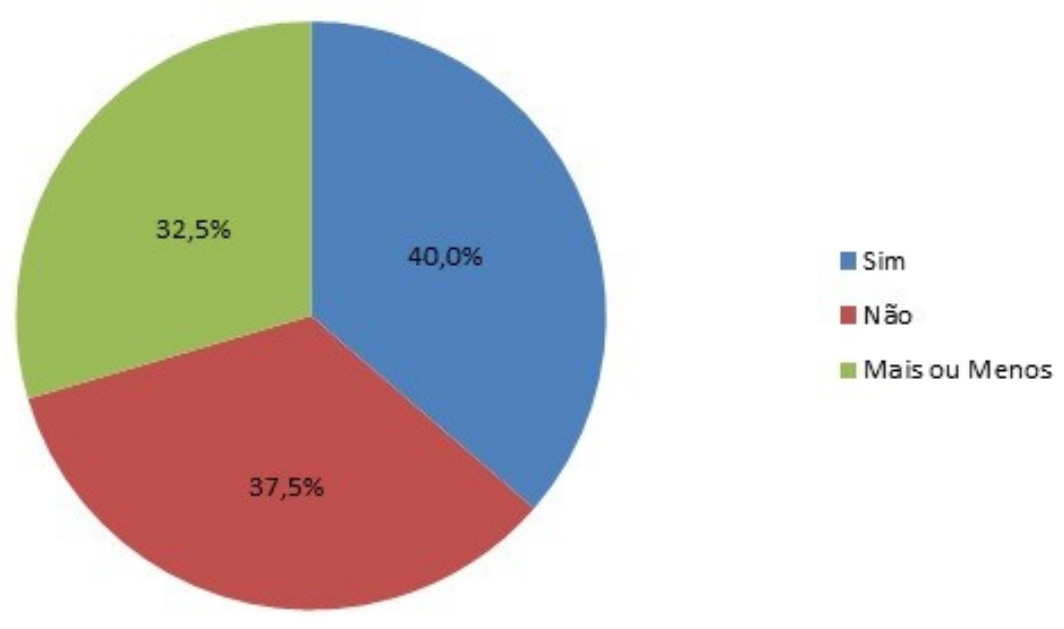

Questão 6 Presencial

No questionamento sobre a percepção das intervenções ficou evidente que a grande maioria já havia registrado a presença das intervenções visuais urbanas nesses espaços, já que 16 pessoas responderam "sim" e 13, "mais ou menos", ou seja, 29 respostas positivas quanto à percepção das mensagens. Tal resultado parece coerente com o trânsito não tão rotineiro pelo local apontado em questão anterior.

\section{Já parou alguma vez para observar melhor?}

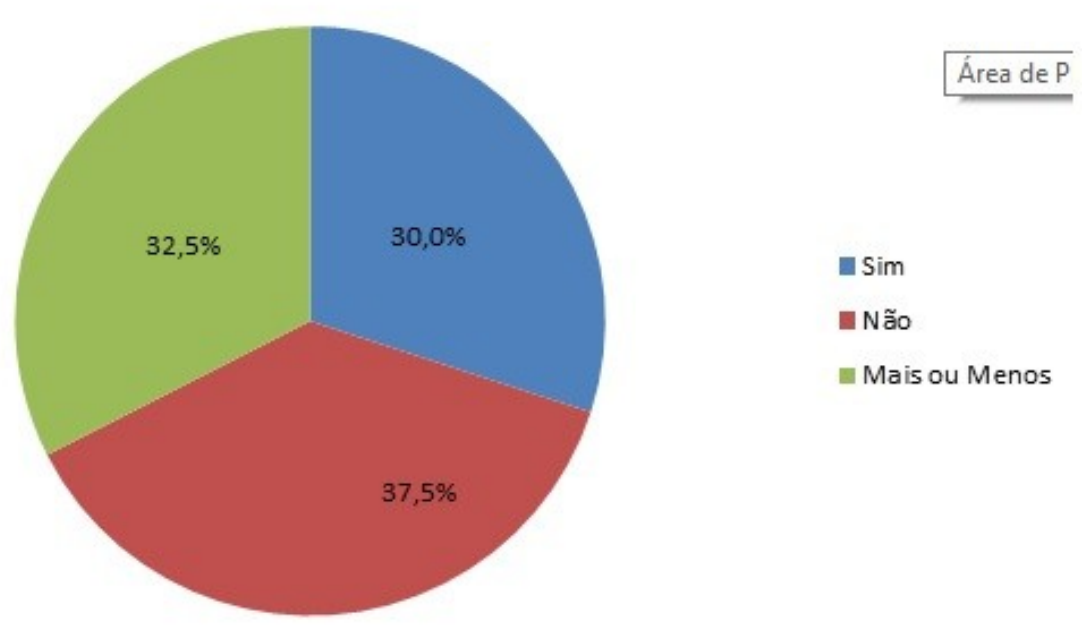

Questão 7 Presencial

A maior parte dos entrevistados afirmou que não parou para observar melhor, porém quando se verifica que os que afirmam "sim" e "mais ou menos" representam 
maior quantidade dos respondentes (26), observa-se que a maior parte registra já ter prestado mais atenção às intervenções visuais urbanas. Logo, elas ocupam espaço, presentificam-se, atuam.

Concluído o levantamento sobre o perfil e a percepção da existência das mensagens pela cidade, inicia-se a coleta de respostas relativas à absorção e interpretação das mesmas.

A questão número $8^{8}$ indaga quanto à impressão sobre esse tipo de mensagem e solicita que os entrevistados mencionem 3 adjetivos que as classifiquem. Dos 40 respondentes, apenas 31 mencionaram adjetivos, que se concentraram em torno do seguintes grupos de noções adjetivas, aqui estabelecidas por proximidade de sentido e mesmo campo semântico:

a) belo, artístico e criativo;

b) ação de vandalismo, sujeira

c) bom, auxiliar e reflexivo

As respostas se dividiram entre esses três agrupamentos de adjetivos. Ressalte-se que dois dos grupos ( $\mathrm{a}$ e $\mathrm{c}$ ) podem ser entendidos como positivos, especialmente em relação ao foco do presente projeto, que busca perceber a atuação das mensagens pela cidade pela cidade, ou seja, a seu favor, promovendo noções relacionáveis a afeto.

\section{Alguma desssas intervenções já lhe chamou atenção? Por quê?}

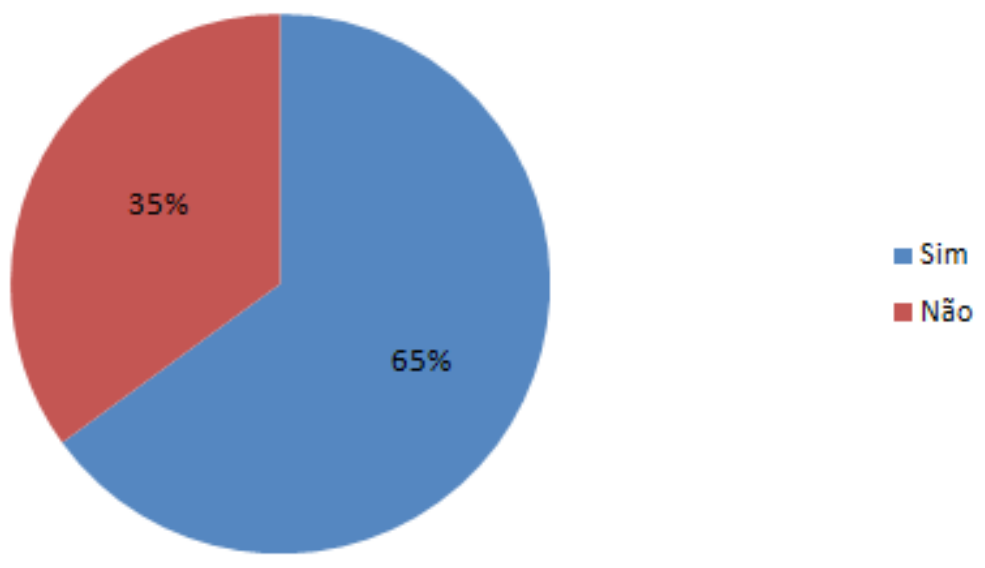

Questão 9 Presencial

8 Disponível nos Apêndices. 
$\mathrm{Na}$ questão 9 que indaga-se se alguma das intervenções chamou atenção do respondente e por quê. Obteve-se 24 respostas de 40. Aqui estabeleceu-se uma primeira divisão entre as respostas afirmativas (sim, já chamaram a atenção) e as negativas (não, não chamaram a atenção). A seguir foram agrupadas as 2 opções acrescidas da justificativa, que se concentrou em aspectos de forma/estéticos e de conteúdo/mensagem, no caso afirmativo. Já no caso da resposta negativa, as justificativas dizem respeito a motivações do próprio transeunte (pressa ou falta de interesse) ou ao aspecto estético (feio, sujo).

a) Sim, porque:

- são bonitos, interessantes e chamativo; são feios (1 resposta) - aspecto estético;

- o conteúdo é relevante, a mensagem é instigante, colabora com a cidade conteúdo, temática.

Dentre as opções, a mais mencionada foi a referente ao âmbito estético.

b) Não, porque:

- pressa; não interesse;

- é sujo e feio;

- sem justificativa.

A questão de número 10 interroga sobre a percepção de que essas mensagens visuais promovem o afeto e a reflexão para a melhora da sociedade e solicita justificativa. Somente 24, dos 40 entrevistados, responderam. Neste caso, 3 agrupamentos de justificativas se equilibraram, sempre justificando a resposta positiva, obtendo cerca de 7 respostas cada um.

a) estética agradável;

b) conteúdo reflexivo e sobre a cidade;

c) relação com a cidade, seja pelo local em que são manifestas, seja por referirem aspectos da realidade vivenciada no local.

Já a percepção negativa usou como justificativa a estética desagradável ou a impressão agressiva e foi expressa por 3 respondentes.

Entrevistas on-line: 
A pesquisa foi aplicada em meio on-line usando-se a ferramenta Formas do Google, durante um período de 48 horas. Para o crivo foi adotado um método eliminatório em que a primeira pergunta consistia em saber se as pessoas usavam ou não as passagens subterrâneas. Ao todo foram respondidos 37 questionários, dos quais apenas 27 passaram pelo crivo, ou seja, tiveram suas respostas consideradas pois afirmaram usar costumeiramente ou já terem usado as passagens subterrâneas da Asa Sul.

Da mesma forma que na estrutura do questionário online, seguiu-se o estabelecimento do perfil dos respondentes.

Gênero (27 responses)

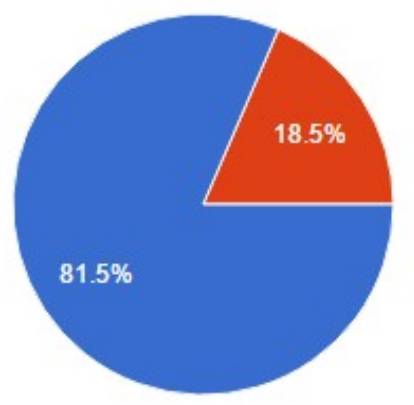

Questão 1 Online

A amostra apresentou como maioria o gênero feminino, que representou 22 dos entrevistados; os outros 5 respondentes afirmaram ser do gênero masculino. 


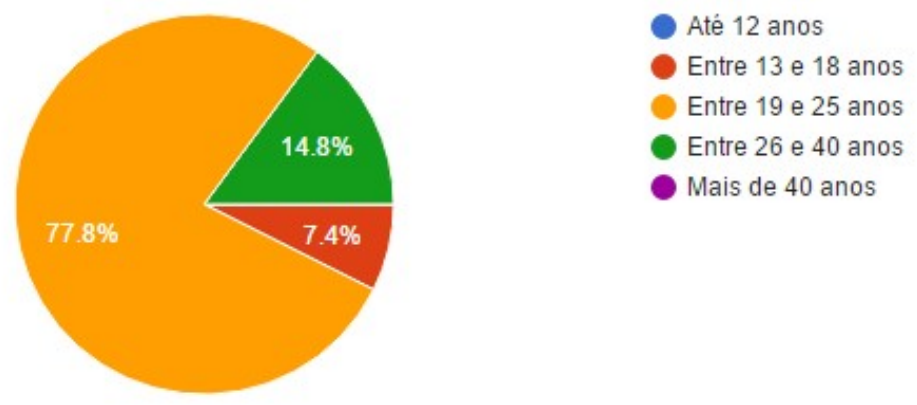

Questão 2 Online

A faixa etária predominante foi de 19 a 25 anos com 21 dos respondentes, seguida de 26 e 40 anos com 4 respondentes e uma pequena parcela com 13 a 18 anos, formado por 2 respondentes.

Escolaridade (27 responses)

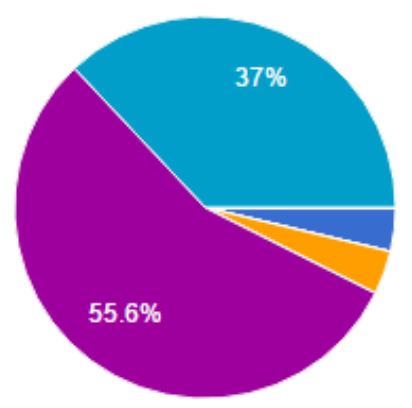

Ensino Fundamental incompleto

Ensino Fundamental completo

Ensino Médio incompleto

Ensino Médio completo

- Graduação incompleta

Graduação completa

Pós-graduação incompleta

Pós-graduação completa

Questão 3 Online

O grau de escolaridade dominante foi dos graduandos, com 15 representantes, seguido de 10 graduados e, na mesma quantidade, estudantes do ensino médio e do fundamental.

Em comparação com a pesquisa presencial, o perfil dos respondentes apresentou maior parcela de respondentes do gênero feminino, correspondência com a 
pesquisa presencial em relação à faixa etária e à escolaridade. Todos esses fatores devem ser percebidos aqui junto à variável de que a pesquisa por meio virtual se ampara, especialmente em curto tempo e amostra pequena, como é o caso aqui, na rede de contatos da pesquisadora que dispara a pesquisa.

Motivo de transitar pelo local (27 responses)

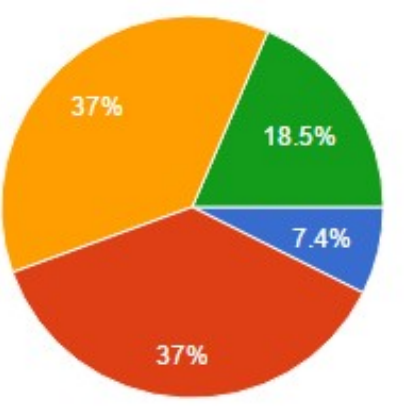

Ida ou volta do trabalho

Ida ou volta da escola ou faculdade

Passeio

Outro motivo

\section{Questão 4 Online}

Quanto ao motivo dominante de passar pelas passarelas, 10 respondentes declaram ser para ir e voltar da escola e/ou faculdade, e o mesmo número, para passear. Assim, dos 27 entrevistados, 20 representantes parecem ter como motivação de trânsito local aspectos coerentes com sua realidade de jovens estudantes, apontada no perfil. Dos demais, 5 disseram transitarem pelo local por outros motivos, e 2, para a ida ao trabalho. 
Frequência que passa pelo local (27 responses)

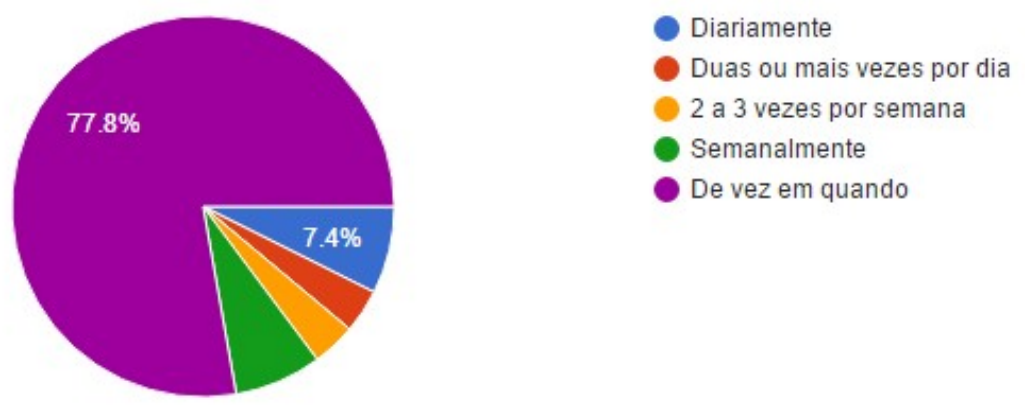

Questão 5 Online

Quanto à frequência, encontrou-se correspondência com os dados obtidos na pesquisa presencial, isto é, a maioria dos entrevistados (21) disse que passam pelas passarelas de vez em quando, seguido das opções diariamente e semanalmente com 2 respondentes.

Já percebera as intervenções(grafite, colagens, pichações)? (27 responses)

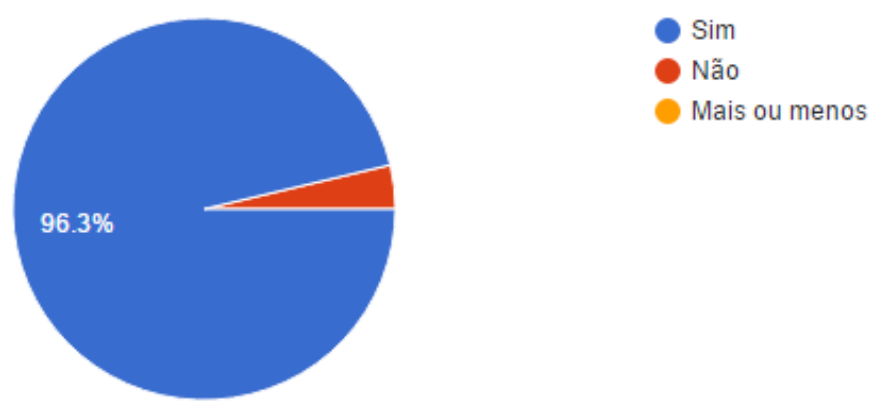

Questão 6 Online

Na questão relativa à percepção da existência das intervenções visuais urbanas, o resultado é gritante: apenas 1 pessoa, das 27, não percebera as intervenções. Tal resultado difere bastante do obtido na pesquisa presencial. 


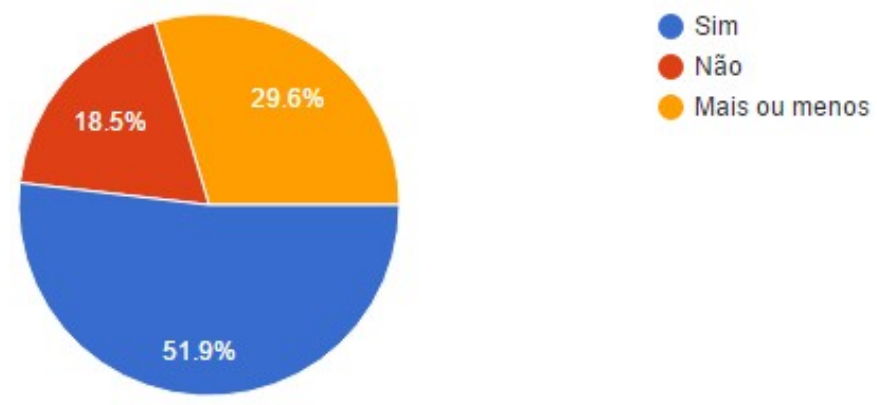

Questão 7 Online

Embora na questão anterior, se observe um dado gritante quanto à quantidade dos respondentes que declaram já ter percebido a existência das mensagens pela cidade, aqui as respostas aparecem mais divididas e equilibradas quanto às diferentes opções - sim, não ou mais menos. Dos entrevistados, 14 afirmaram que sim, já pararam para observar melhor as intervenções visuais, 8 entrevistados marcaram mais ou menos como resposta, e 5 disseram que não. Tal resultado é semelhante ao conferido na pesquisa presencial em relação ao percentual dos que disseram ter percebido a existência das imagens e, destes, quantos pararam para observar melhor.

Na questão número 8 , quanto à impressão sobre esse tipo de mensagem e a menção de 3 adjetivos que as classifiquem, dos 27 respondentes apenas 20 fizeram comentários acerca das impressões que têm. Seguem os grupos de noções adjetivas referidas, aqui estabelecidas por proximidade de sentido e mesmo campo semântico:

a) belo, artístico e criativo;

b) ação de vandalismo, sujeira

c) bom, auxiliar e reflexivo

Aqui, diferente do que aparece na presencial, o agrupamento a foi amplamente escolhido, seguido pelo b (negativo) e, então, em bem menor número, pelo 
agrupamento c. Ou seja, na pesquisa on-line a visão positiva ainda predominou mas não tão fortemente como na presencial.

\section{Algumas dessas intervenções já Ihe chamou a atenção? Por quê? (27 responses)}
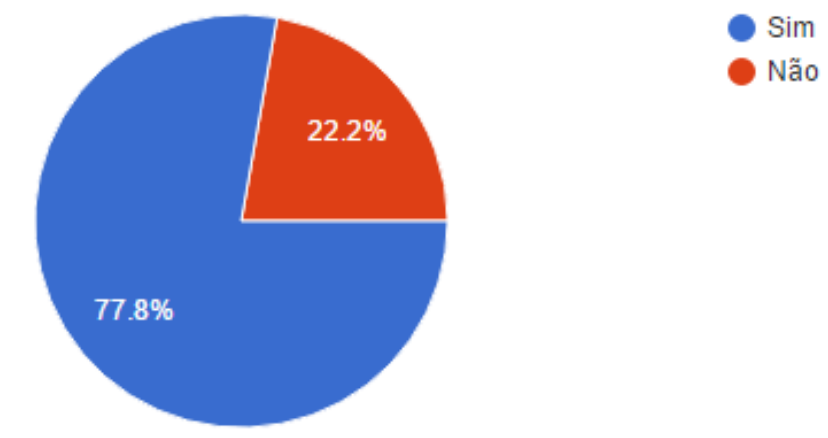

Não

Questão 9 Online

A questão 9 indaga se alguma das intervenções chamou atenção do respondente e por quê, pedindo que cite o motivo, ou seja, é uma questão, mista de assinalar uma opção e justificar. Dos 27 entrevistados, 21 marcaram sim, e o restante, 6, não. Os motivos que os respondentes apontaram sobre o que faz a intervenção chamar atenção foram positivos e concentraram-se assim:

a) no aspecto estético (bonito, chamativo);

b) no conteúdo (relevante, instigante, colabora com a cidade).

Porém aqui, diferente da pesquisa presencial, a justificativa mais usada referiu-se ao aspecto temático, de conteúdo, de relação com a cidade e o cotidiano, e não ao aspecto estético.

A questão de número 10 interroga sobre a percepção de que essas mensagens visuais promovem o afeto e a reflexão para a melhora da sociedade e solicita justificativa. Neste caso, 21 pessoas responderam. Destes, 17 responderam positivamente, justificando, em ordem quantitativa de menção, por:

a) relação com a cidade, seja pelo local em que são manifestas, seja por referirem aspectos da realidade vivenciada no local;

b) conteúdo reflexivo e sobre a cidade;

c) estética agradável. 
Já os que manifestaram discordância quanto à possibilidade de as mensagens promoverem afeto e reflexão no sentido da melhora da cidade, os argumentos se concentraram na não efetividade da leitura/percepção dessas mensagens.

A pesquisa de campo como um todo apontou que a maior parte dos entrevistados percebe as mensagens pela cidade e também que elas atuam a favor do convívio positivo no espaço público urbano. Embora a amostra seja reduzida e haja pequenas variações quanto às respostas obtidas em modo presencial ou on-line, a avaliação positiva das intervenções visuais urbanas se mantém.

\section{e) CONSIDERAÇÕES FINAIS}

Este projeto se propôs, como objetivo geral, identificar como intervenções urbanas realizadas em Brasília, nas passarelas subterrâneas da Asa Sul, podem atuar a favor da humanização da cidade. A partir da suposição inicial de que é possível, via intervenções visuais urbanas, atuar favoravelmente em relação a um clima de afeto, reflexão e positividade, procurou-se vislumbrar a possibilidade de Brasília revelar-se mais humana.

Para tanto, além da digestão de estudos referentes a espaço público e sua ocupação afetiva, comunicação, percursos e recursos de geração de sentido, intervenções visuais urbanas, executou-se um levantamento fotográfico de mais de duas centenas de mensagens visuais dispostas nas passarelas subterrâneas da Asa Sul, Brasília - DF, seu mapeamento, a análise de 35 delas via tricotomias peirceanas, para estabelecer características e relações entre os mecanismos estruturadores de sentido e, assim, cogitar seus núcleos de significação e a relação destes com o foco do trabalho - a possibilidade de promoção de afeto na cidade via as intervenções visuais nela dispostas, e, ainda, lançou-se sobre seu conjunto um olhar orientado pelos procedimentos de controle discursivo - cunhados por Foucault - na perspectiva de estabelecer a ligação entre as escolhas predominantemente feitas e o propósito assim perceptível nas mensagens pela cidade. Tanto a análise semiótica quanto o olhar da análise do discurso de vertente francesa apontam a dominância de escolhas que privilegiam o intento comunicativo e o desejo de atingir 
os transeuntes, de forma mais clara e direcionada (via os recursos verbais), na direção da possibilidade reflexiva e humanizadora da vida urbana.

Por fim, para acrescentar algo da possível perspectiva dos próprios transeuntes dos locais onde foi realizado o levantamento fotográfico das mensagens, realizou-se pesquisa de campo, por meio de questionário estruturado, tanto de modo presencial, em algumas das passarelas, quanto por meio on-line. As respostas obtidas na pesquisa corroboram na confirmação da potencialidade comunicativa das mensagens analisadas, uma vez que trazem predominância de percepções positivas das intervenções urbanas e a tradução dessa positividade amparada tanto em aspectos estéticos quanto de conteúdo dessas mensagens no sentido de atenção e reflexão sobre a vivência urbana.

Assim, o estudo ampara a percepção inicial da capacidade de ação que as mensagens pela cidade têm de atuarem a favor da boa convivência na cidade. Logo, conclui-se que a inserção do recurso de intervenções visuais no ambiente urbano, de trânsito de pessoas, pode ser muito expressivo e que seu funcionamento enquanto recurso promotor de reflexões estimuladoras de afeto é percebido, muitas vezes desejado, mas ainda não ocorre de modo todo consciente.

O projeto cumpriu seus objetivos, embora tenha enfrentado pequenas dificuldades, como a dificuldade de as pessoas se disporem a responder o questionário, especialmente de modo presencial. A insegurança percebida nesses ambientes é uma das variáveis atribuídas a isso e, também, elemento dificultador da realização do levantamento fotográfico. Se o espaço público fosse mais valorizado tanto pelo poder público quanto pelos próprios cidadãos, talvez a própria comunicação poética e cidadã que se constitui nas intervenções visuais urbanas fosse mais efetiva em seu potencial transformador da vida em coletividade.

Este estudo permite ainda muitas derivações, seja em relação a aprofundamento teórico quanto a compreensões da atuação cidadã e do hibridismo e circularidade como características desse tipo de ação comunicativa, seja em relação aos espaços analisados, que deveriam buscar uma perspectiva mais descentralizada no âmbito territorial, verificando, por exemplo, como se dá o uso dessas mensagens nas cidades satélites de Brasília. 


\section{REFERÊNCIAS}

AGAPITO, Amanda. Brasília para pessoas. Revista eletrônica Universitas, vol. 10, $\mathrm{n}^{\circ}$ 2, 2013. DOI: .10.5102/uc.v10i2.2133.

AUGÉ, Marc. Não-lugares: Introdução a uma antropologia da supermodernidade. Tradução: Maria Lúcia Pereira. Campinas, SP: Papirus, 1994.

BAITELLO Jr., Norval. A era da iconofagia. São Paulo: Hacker Editores, 2005. BARTHES, Roland. A aventura semiológica. São Paulo: Martins Fontes, 2001. BAUMAN, Zygmunt. Modernidade líquida. Rio de Janeiro: Zahar, 2001. BORDENAVE, Juan E. Díaz. O que é comunicação. São Paulo: Editora Brasiliense, 1982.

DAMIÃO, Wisgner; DIESEL, Ursula. A despersonificação do lar: o não-lugar como objeto de consumo da pós-modernidade. Revista eletrônica Universitas, vol. 10, $\mathrm{n}^{\circ}$ 2, 2013. DOI: 10.5102/uc.v10i2.1967

FOUCAULT, Michel. A Ordem do Discurso. São Paulo: Loyola, 1996.

GEHL, Jan; GEMZOE, Lars. Novos espaços urbanos. Barcelona: Editorial Gustavo Gili, 2002.

GIL, Antônio C. Métodos e técnicas de pesquisa social. São Paulo: Atlas, 2002.

GODOY, Arilda Schmidt. Pesquisa Qualitativa: Tipos Fundamentais. Disponível: http://www.scielo.br/pdf/rae/v35n3/a04v35n3.pdf. Acesso em: 26/07/2016

HABERMAS, Jurgen. Teoria de La Acción comunicativa I Racionalidad de La y racionalización social. Madri: Taurus, 1987.

LAUANDE, Francisco. O projeto para o Plano-piloto e o pensamento de Lúcio Costa. Disponível em <http://www.vitruvius.com.br/revistas/read/arquitextos/08.087/223>. Acesso em 19 de set de 2012.

MCLUHAN, Marshal. Os meios de comunicação como extensões do homem. 15a reimpressão. São Paulo: Cultrix, 2007.

MONTANER, Josep Maria. Depois do movimento moderno: Arquitetura da segunda metade do século XX. Tradução: Maria Beatriz da Costa Mattos. Barcelona: Editorial Gustavo Gili, 2001.

RUSSI, Pedro. Provocações e ação do signo: "pichações". In: RUSSI, P. (org.) Processos semióticos em comunicação. Brasília: Editora UnB, 2013.

SANTAELLA, Lúcia. O que é semiótica. São Paulo: Editora Brasiliense, 1983. SANTAELLA, Lúcia. Comunicação e pesquisa: projetos para mestrado e doutorado. São Paulo: Hackers, 2001.

SANTAELLA, Lúcia. Semiótica aplicada. São Paulo: Pioneira Thomson Learning, 2002.

VIEIRA, Valter Afonso; TIBOLA, Fernando. Pesquisa qualitativa em marketing e suas variações: trilhas para pesquisas futuras. Disponível: < $<$ http://www.scielo.br/scielo.php?pid=S1415-

65552005000200002\&script=sci_arttext>. Acesso em 26/07/2016. 


\section{APÊNDICES}

a) Análise das imagens

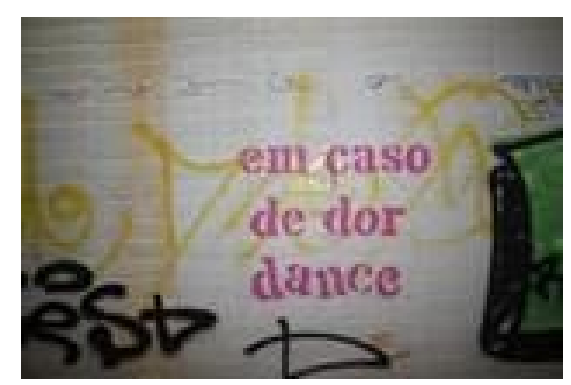

Figura 8 Quadra 114, Asa Sul

Autora: a pesquisadora

\begin{tabular}{|l|l|}
\hline Primeira Tricotomia & Segunda Tricotomia \\
\hline Quali-signo: cor rosa & Í́ne: ---á----- \\
\hline $\begin{array}{l}\text { Sin signo: frase na cor } \\
\text { rosa em língua }\end{array}$ & Índice: técnica de stencil \\
portuguesa & \\
\hline $\begin{array}{l}\text { Legi signo: frase "em } \\
\text { caso de dor dance" na } \\
\text { cor rosa feita sob a a } \\
\text { técnica de stencil }\end{array}$ & $\begin{array}{l}\text { suavidade, alegre; stencil= repetição, intenção } \\
\text { comunicativa com maior alcance, abordagem clara; "em } \\
\text { caso de dor dance" =indicação para melhorar as dores } \\
\text { com "medicação natural". }\end{array}$ \\
\hline
\end{tabular}

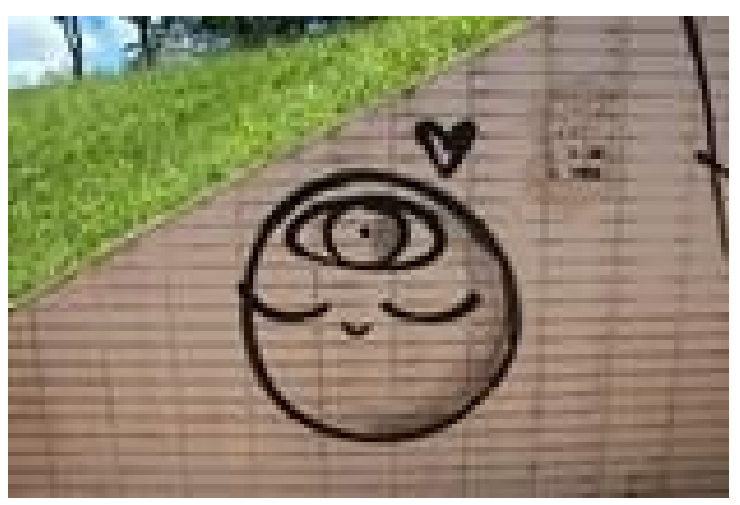

Figura 9 Quadra 114, Asa Sul

Autora: a pesquisadora 


\begin{tabular}{|l|l|}
\hline Primeira Tricotomia & Segunda Tricotomia \\
\hline Quali signo: mancha preta & Ícone: coração, cabeça e olho. \\
\hline $\begin{array}{l}\text { Sin signo: circulo sem } \\
\text { preenchimento na cor preta } \\
\text { em fundo branco }\end{array}$ & Índice: técnica de spray \\
\hline $\begin{array}{l}\text { Legi signo: desenho do } \\
\text { contorno da cabeça do }\end{array}$ & $\begin{array}{l}\text { Símbolo: esboço personagem Gurulino = traço do } \\
\text { personagem sem preenchimento; olhos relaxados = } \\
\text { personagem Gurulino e um } \\
\text { indica tranqüilidade, espiritualidade. terceiro olho = } \\
\text { capacidade de maior visão, sabedoria. Coração = } \\
\text { intuição, está acima da cabeça e semi preenchido } \\
\text { indicando que há harmonia e é guiado pela emoção } \\
\text { e não pela raz }\end{array}$ \\
\hline
\end{tabular}

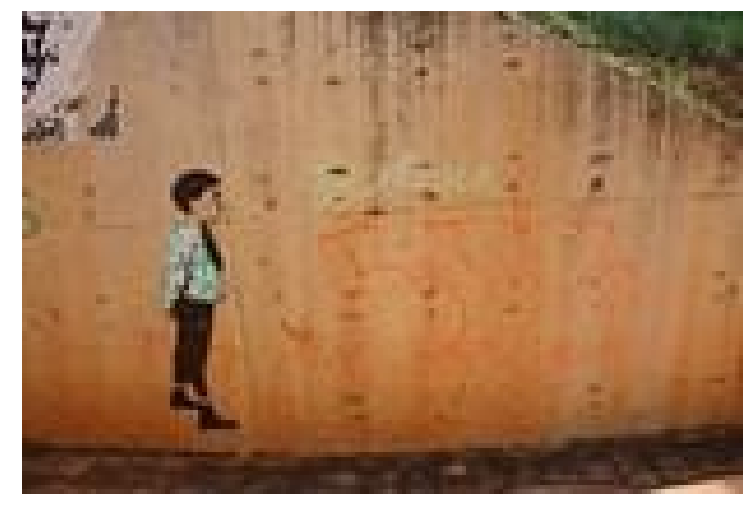

Figura 10 Quadra 114, Asa Sul

Autora: a pesquisadora

\begin{tabular}{|l|l|}
\hline Primeira Tricotomia & Segunda Tricotomia \\
\hline Quali signo: macha escura & Ícone: menino, sapato, roupa. \\
\hline $\begin{array}{l}\text { Sin signo: desenho de uma } \\
\text { criança }\end{array}$ & Índice: técnica colagem. \\
\hline $\begin{array}{l}\text { Legi signo: Colagem da } \\
\text { figura de um menino no }\end{array}$ & $\begin{array}{l}\text { Símbolo: figura de um menino = criança, } \\
\text { ingenuidade; traje social = normas, regras; Braços } \\
\text { subterrânea. de uma passagem } \\
\text { para trás e segurando as mãos = rigidez, } \\
\text { maturidade é uma posição de adultos que estão } \\
\text { analisando uma situação, o que não é comum para } \\
\text { meninos da idade que ele remete. }\end{array}$ \\
\hline
\end{tabular}




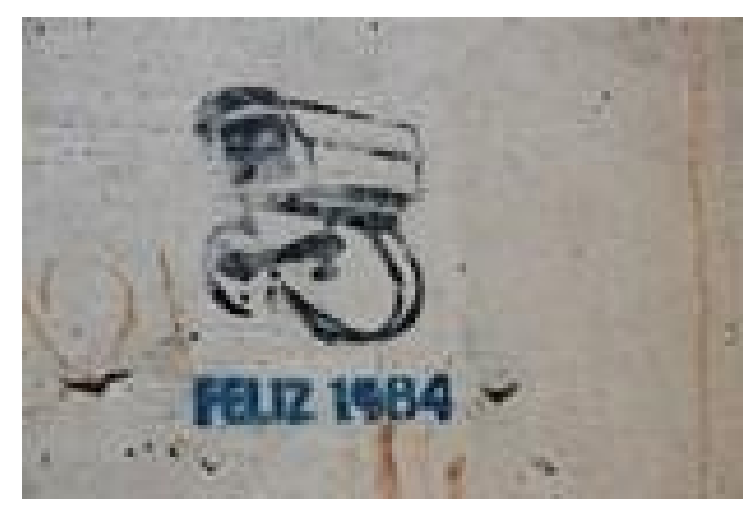

Figura 11 Quadra 109, Asa Sul

Autora: a pesquisadora

\begin{tabular}{|l|l|}
\hline Primeira Tricotomia & Segunda Tricotomia \\
\hline Quali signo: linhas pretas & Ícone: câmera, fio \\
\hline Sin signo: esboço de um objeto & Índice: técnica de stencil. \\
\hline Legi signo: esboço de uma & Símbolo: Câmera de segurança inclinada = \\
câmera de segurança em cor & posição de filmagem, gravando, monitorando; cor \\
preta e a frase "Feliz 1984" & preta: padrão, respeito; frase "Feliz 1984" = \\
& felicitando pelo ano de 1984, ano que acabou a \\
& ditadura militar no Brasil, diretas já; cor azul = \\
& tranqüilidade, harmonia. \\
\hline
\end{tabular}

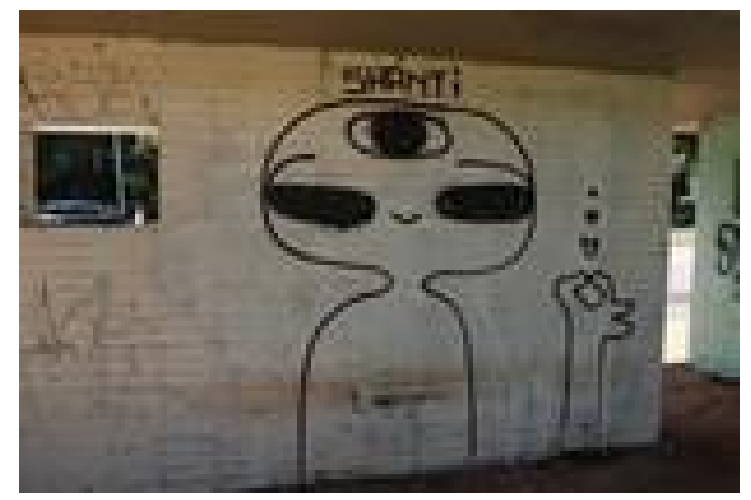

Figura 12 Quadra 109, Asa Sul

Autora: a pesquisadora

\begin{tabular}{|l|l|}
\hline Primeira Tricotomia & Segunda Tricotomia \\
\hline Quali signo:mancha preta & Í́cone: olhos, mão, coração \\
\hline $\begin{array}{l}\text { Sin signo: desenho sem } \\
\text { preenchimento em cor preta e em } \\
\text { fundo branco. }\end{array}$ & \\
\hline Legi signo: Desenho do do & Símbolo: Mudras = sinal de pressionar \\
\hline
\end{tabular}




\begin{tabular}{|l|l|}
\hline personagem Shanti sem & $\begin{array}{l}\text { polegar com dedo indicador, sinal de } \\
\text { preenchimento e traço na cor preta. } \\
\text { meditação, ligado a energia; corações = } \\
\text { harmonia, pureza espiritual; Shanti = nome } \\
\text { do personagem; terceiro olho = sabedoria, } \\
\text { sensitivo. }\end{array}$ \\
\hline
\end{tabular}

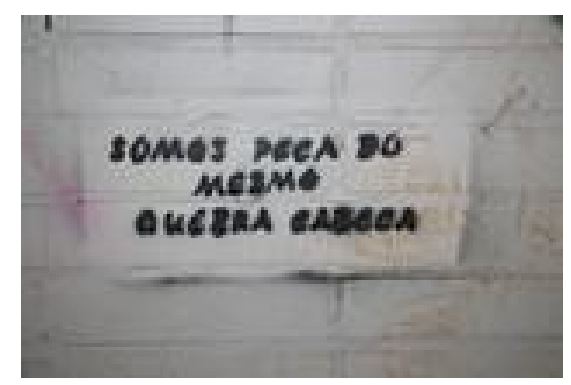

Figura 13 Quadra 110/111, Asa Sul

Autora: a pesquisadora

\begin{tabular}{|c|c|}
\hline Primeira Tricotomia & Segunda Tricotomia \\
\hline Quali signo:cor preta & Ícone: \\
\hline $\begin{array}{l}\text { Sin Signo: frase na cor preta e fundo } \\
\text { na cor branca }\end{array}$ & Índice: técnica stencil. \\
\hline $\begin{array}{l}\text { Legi signo: frase "Somos peça do } \\
\text { mesmo quebra cabeça" feita com } \\
\text { spray e ao fundo das paredes da } \\
\text { passarela subterrânea na cor branca }\end{array}$ & $\begin{array}{l}\text { Símbolo: a frase "Somos peça do mesmo } \\
\text { quebra cabeça" = promovendo a união } \\
\text { entre as pessoas, que as diferenças } \\
\text { existem para se completar; cor preta = } \\
\text { padrão, melhor visualização. }\end{array}$ \\
\hline
\end{tabular}

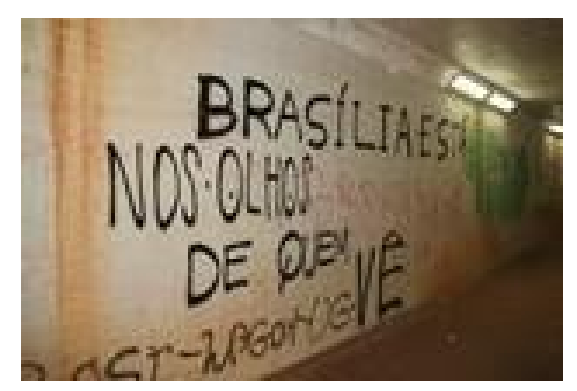

Figura 14 Quadra 110/111, Asa Sul

Autora: a pesquisadora

\begin{tabular}{|l|l|}
\hline Primeira Tricotomia & Segunda Tricotomia \\
\hline Quali signo: cor preta e fundo branco & Ícone: \\
\hline
\end{tabular}




\begin{tabular}{|l|l|}
\hline Sin signo: frase feita de forma livre com spray & Índice: técnica spray e livre traço. \\
\hline Legi signo:frase "Brasília está nos olhos de & Símbolo: a frase "Brasília está \\
quem vê" feita com spray na cor preta na & nos olhos de quem vê" = Brasília \\
parede da passagem subterrânea da Asa Sul & capital do Brasil, a frase fala das \\
que tem fundo de cor branca & $\begin{array}{l}\text { várias facetas que a cidade tem e } \\
\text { a impressão que as pessoas com } \\
\text { opiniões diferentes tem; letras } \\
\text { irregulares }=\text { desconforme ao } \\
\text { padrão de grafia, sem } \\
\text { uniformidade. }\end{array}$ \\
\hline
\end{tabular}

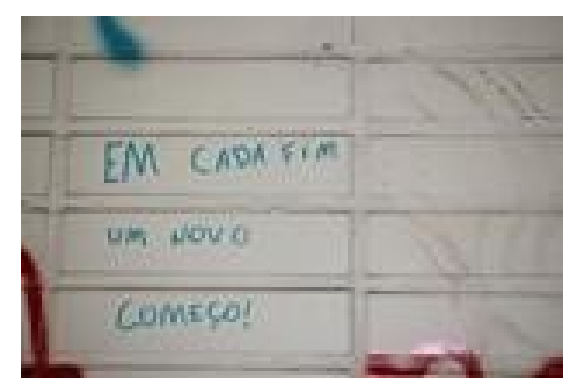

Figura 15 Quadra 110/111, Asa Sul

Autora: a pesquisadora

\begin{tabular}{|l|l|}
\hline Primeira Tricotomia & Segunda Tricotomia \\
\hline $\begin{array}{l}\text { Quali signo: cores azul e } \\
\text { branca }\end{array}$ & Ícone: \\
\hline $\begin{array}{l}\text { Sin signo: frase na cor } \\
\text { azul em fundo branco }\end{array}$ & Índice: técnica de pincel com mão livre. \\
\hline $\begin{array}{l}\text { Legi signo: frase "em } \\
\text { cada fim um novo } \\
\text { começo" }\end{array}$ & $\begin{array}{l}\text { Símbolo: a frase "Em cada fim um novo começo!" = } \\
\text { frase motivadora, remete a ciclos da vida que iniciam e } \\
\text { chegam ao fim e novos surgiram; letras de tamanhos } \\
\text { irregulares = sem padrão, improviso; cor azul: leveza, } \\
\text { renovação. }\end{array}$ \\
\hline
\end{tabular}




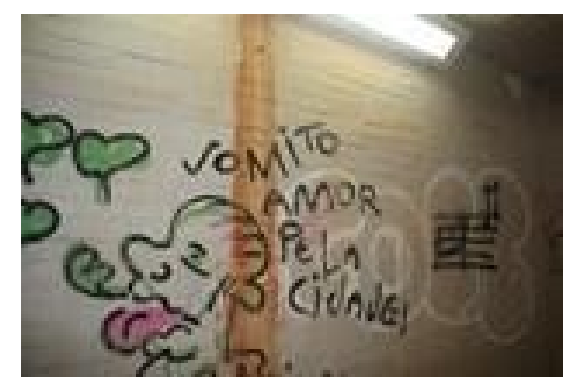

Figura 16 Quadra 110/111, Asa Sul Autora: a pesquisadora

\begin{tabular}{|l|l|}
\hline Primeira Tricotomia & Segunda Tricotomia \\
\hline Quali signo: cor verde e preta & Ícone: língua, coração, pessoa \\
\hline Sin signo: frase feita com spray na & Índice: técnica de traço livre com spray. \\
cor preta e desenho de uma pessoa & \\
e de corações & \\
\hline Legi signo:frase "Vomito amor pela & Símbolo: frase "vomito amor pela cidade!" = \\
cidade!" feita com spray e desenho & frase que brinca com as palavras vomito e \\
de uma pessoa com a língua de & amor, já que vomito remete a algo que foi \\
fora dando a impressão que está & $\begin{array}{l}\text { rejeitado e amor que remete a } \\
\text { vemonstrações; cor verde = nojento, }\end{array}$ \\
& $\begin{array}{l}\text { desagradável; cor preta = padrão; cor } \\
\text { vermelha = chamativa. }\end{array}$ \\
\hline
\end{tabular}

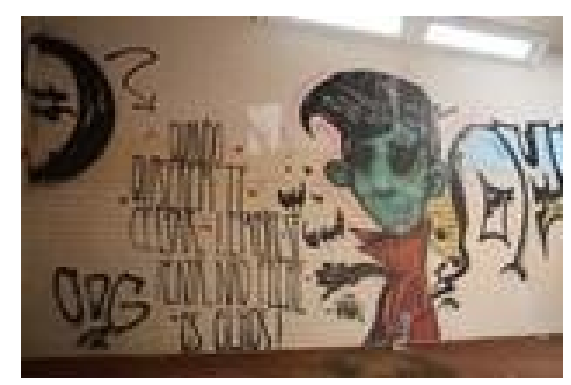

Figura 17 Quadra 110/111, Asa Sul Autora: a pesquisadora

\begin{tabular}{|l|l|}
\hline Primeira Tricotomia & Segunda Tricotomia \\
\hline Quali signo:manchas & Ícone: \\
coloridas & \\
\hline Sin signo: frase escrita a & Índice: técnica de spray. \\
mão livre em caixa alta e & \\
\hline
\end{tabular}




\begin{tabular}{|l|l|}
\hline $\begin{array}{l}\text { na cor preta e um desenho } \\
\text { colorido. }\end{array}$ & \\
\hline $\begin{array}{l}\text { Legi signo: frase "Quando } \\
\text { disserem te ceifar, lembre- } \\
\text { se reaja não feche os } \\
\text { olhos." }\end{array}$ & $\begin{array}{l}\text { Símbolo: representação de um rapaz com } \\
\text { frase que deixou se influenciar pelo o meio; frase } \\
\text { "Quando disserem te ceifar, lembre-se reaja não feche } \\
\text { os olhos." = incentiva reagir e fazer diferente; cor } \\
\text { verde = desagradável, oposto a vitalidade; olhos ocos } \\
=\text { característica de zumbi, ausência de cérebro, ser } \\
\text { não pensante. }\end{array}$ \\
\hline
\end{tabular}

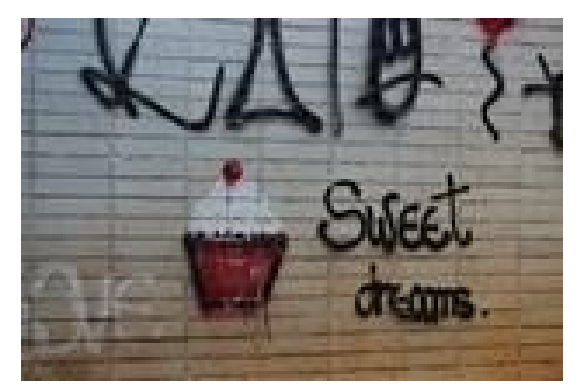

Figura 18 Quadra 110/111, Asa Sul

Autora: a pesquisadora

\begin{tabular}{|l|l|}
\hline Primeira Tricotomia & Segunda Tricotomia \\
\hline $\begin{array}{l}\text { Quali signo: mancha } \\
\text { vermelha e preta }\end{array}$ & Ícone: desenho de um cupcake e a frase "sweet dreams" \\
\hline $\begin{array}{l}\text { Sin signo: desenho de } \\
\text { um cupcake e uma } \\
\text { frase }\end{array}$ & \\
\hline $\begin{array}{l}\text { Legi signo: Cupcake: técnica spray. } \\
\text { vermelho e branco e a } \\
\text { frase "sweet dreams" }\end{array}$ & $\begin{array}{l}\text { Símbolo: desenho cupcake = bolo unitário, característico } \\
\text { de doces sonhos infantis; frase "sweet dreams" escrita em inglês } \\
\text { cor branca =.detalhe. }\end{array}$ \\
\hline
\end{tabular}




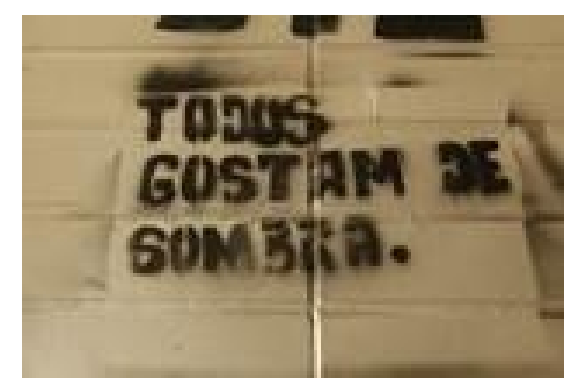

Figura 19 Quadra 108, Asa Sul

Autora: a pesquisadora

\begin{tabular}{|c|c|}
\hline Primeira Tricotomia & Segunda Tricotomia \\
\hline Quali signo: cor preta & Ícone: \\
\hline $\begin{array}{l}\text { Sin signo: palavras em } \\
\text { fundo branco }\end{array}$ & Índice: técnica de stencil \\
\hline $\begin{array}{llr}\text { Legi } & \text { signo: } & \text { frase } \\
\text { "Todos } & \text { gostam } & \text { de } \\
\text { sombra" } & & \\
& & \end{array}$ & $\begin{array}{l}\text { Símbolo: frase "Todos gostam de sombra" = sombra de } \\
\text { árvore, tranquilidade, remete a um gosto comum. }\end{array}$ \\
\hline
\end{tabular}

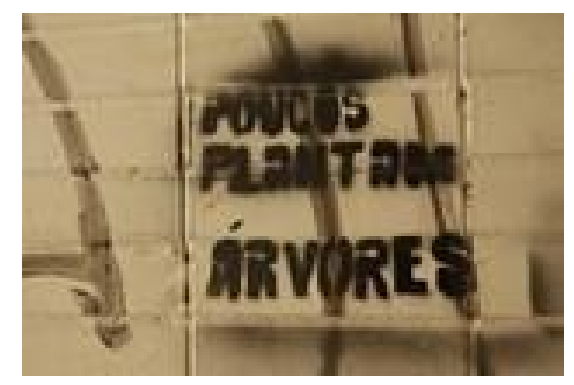

Figura 20 Quadra 108, Asa Sul

Autora: a pesquisadora

\begin{tabular}{|l|l|}
\hline Primeira Tricotomia & Segunda Tricotomia \\
\hline Quali signo: cor preta & Ícone: \\
\hline $\begin{array}{l}\text { Sin signo: palavras } \\
\text { em fundo branco }\end{array}$ & Índice: Técnica de stencil. \\
\hline $\begin{array}{l}\text { Legi signo: frase } \\
\text { "poucos plantam } \\
\text { árvores" }\end{array}$ & $\begin{array}{l}\text { Símbolo: frase "poucos plantam árvores" = é complemento } \\
\text { da frase ao lado que é "Todos gostam de sobram", e critica } \\
\text { ao desmatamento e a falta de um reflorestamento efetivo. }\end{array}$ \\
\hline
\end{tabular}


Figura 21 Quadra 108, Asa Sul

Autora: a pesquisadora

\begin{tabular}{|l|l|}
\hline Primeira Tricotomia & Segunda Tricotomia \\
\hline Quali signo: mancha preta & Ícone: \\
\hline $\begin{array}{l}\text { Sin signo:frase em cor preta em } \\
\text { fundo branco }\end{array}$ & Índice: Técnica stencil. \\
\hline $\begin{array}{l}\text { Legi signo: frase "quando tudo for } \\
\text { pedra. Atire a primeira flor." na cor } \\
\text { preta e usando a técnica stencil. }\end{array}$ & $\begin{array}{l}\text { Símbolo: frase "quando tudo for pedra. Atire a } \\
\text { primeira flor." = quando estiver em um motivadora, inspira a boas } \\
\text { tente ser luz, flor remete a bondade, calmaria; } \\
\text { cor preta = padrão. }\end{array}$ \\
\hline
\end{tabular}

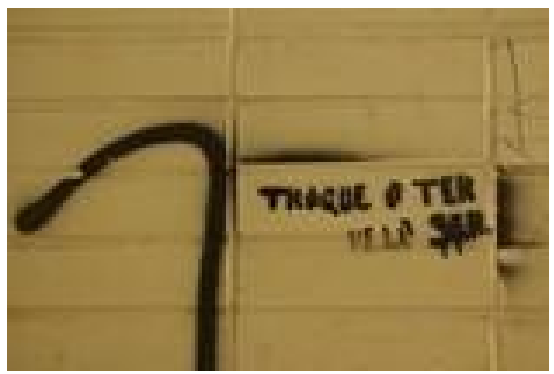

Figura 22 Quadra 108, Asa Sul

Autora: a pesquisadora

\begin{tabular}{|l|l|}
\hline Primeira Tricotomia & Segunda Tricotomia \\
\hline Quali signo:cor preta & Ícone: \\
\hline $\begin{array}{l}\text { Sin signo: frase em cor preta no } \\
\text { fundo branco. }\end{array}$ & Índice: técnica de stencil. \\
\hline $\begin{array}{l}\text { Legi signo: frase "troque o ter pelo } \\
\text { ser" na cor preta e usando a técnica }\end{array}$ & $\begin{array}{l}\text { Símbolo: frase "troque o ter pelo ser"= } \\
\text { promove a existência legitima do ser, } \\
\text { de stencil. }\end{array}$ \\
& $\begin{array}{l}\text { natural, sua essencial e não o ter que é } \\
\text { comprado, artificial; na cor preta = padrão. }\end{array}$ \\
\hline
\end{tabular}




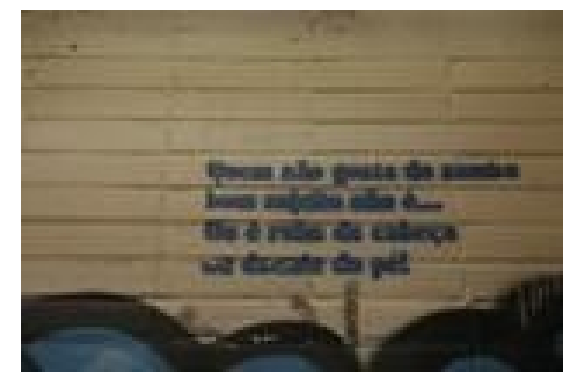

Figura 23 Quadra 108, Asa Sul Autora: a pesquisadora

"Quem não gosta de samba bom sujeito não ... ou é ruim da cabeça ou doente do pé!"

\begin{tabular}{|c|c|}
\hline Primeira Tricotomia & Segunda Tricotomia \\
\hline Quali signo: riscos de cor escura. & Ícone: \\
\hline Sin signo: frase em cor escura. & Índice: Técnica stencil. \\
\hline $\begin{array}{l}\text { Legi signo: Frase “"'Quem não gosta } \\
\text { de samba bom sujeito não ... ou é } \\
\text { ruim da cabeça ou doente do pé!” } \\
\text { em cor azul, em muro de passarela } \\
\text { e feito com a técnica de stencil. }\end{array}$ & $\begin{array}{l}\text { Símbolo: A frase "Quem não gosta de samba } \\
\text { bom sujeito não ... ou é ruim da cabeça ou } \\
\text { doente do pé!" = frase popular no país por } \\
\text { ser verso de uma música popular chamada } \\
\text { "Samba da minha terra" de Dorival Caymmi } \\
\text { de 1940, enaltece o samba como música } \\
\text { popular, e compara ao movimento da dança } \\
\text { que é bem agitado e compassado ao gostar } \\
\text { ou não do estilo. }\end{array}$ \\
\hline
\end{tabular}

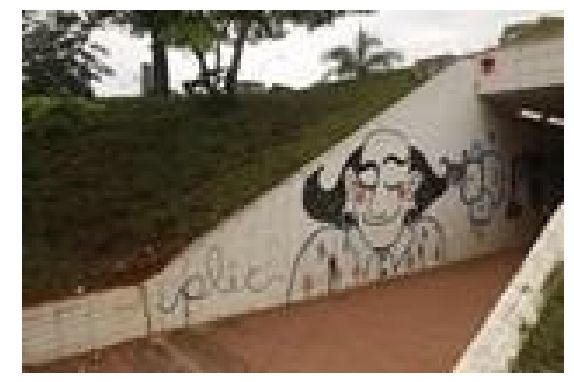

Figura 24 Quadra 106, Asa Sul

Autora: a pesquisadora 


\begin{tabular}{|l|l|}
\hline Quali signo: manchas coloridas. & $\begin{array}{l}\text { Ícone: homem, olhos fechados, cabelos, } \\
\text { brinco, sobrancelha e camisa. }\end{array}$ \\
\hline $\begin{array}{l}\text { Sin signo:cores preto e vermelho em } \\
\text { fundo branco. }\end{array}$ & Índice: Técnica de livre traço e spray. \\
\hline $\begin{array}{l}\text { Legi signo:desenho produzido de um } \\
\text { homem de olhos fechados e sorriso } \\
\text { no rosto. }\end{array}$ & $\begin{array}{l}\text { Símbolo: desenho homem com olhos } \\
\text { fechados = pensativo, prazeroso; e sorriso } \\
=\end{array}$ \\
& leve sotisfação, prazer. \\
\hline
\end{tabular}

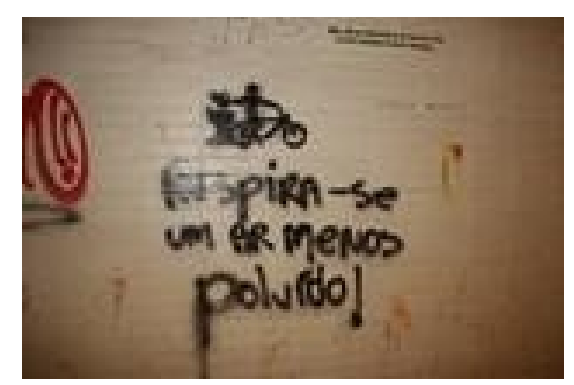

Figura 25 Quadra 106, Asa Sul Autora: a pesquisadora

\begin{tabular}{|l|l|}
\hline Primeira Tricotomia & Segunda Tricotomia \\
\hline Quali signo: riscos pretos. & Ícone: bicicleta, pessoa, lixeira. \\
\hline Sin signo: frase "Respira-se & Índice: Técnica traço livre com spray. \\
um ar menos poluido!" e um & \\
desenho acima da frase. & \\
\hline Legi signo: A frase "Respira- & Símbolo: Frase "Respira-se um ar menos poluido!" = \\
se um ar menos poluido!" e & exemplifica o desenho de como pode respirar um ar \\
o desenho de uma pessoa & menos poluido com atitudes de evitar o uso de carro \\
de bicicleta e jogando um & e jogar lixo no chão ao invés da lixeira; desenho de \\
lixo na lixeira. & $\begin{array}{l}\text { uma pessoa de bicicleta jogando lixo no lixo = } \\
\text { atitude de respeito ao ambiente, jogar lixo na lixeira. }\end{array}$ \\
\hline
\end{tabular}

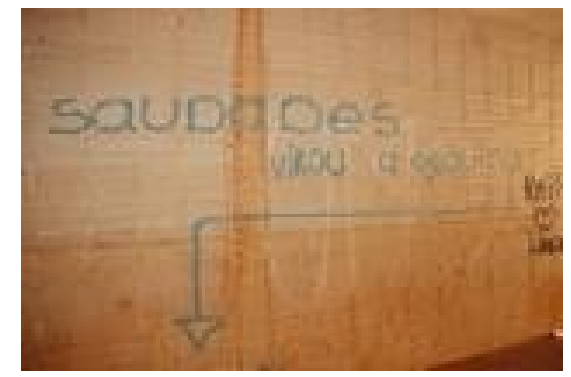

Figura 26 Quadra 106, Asa Sul 


\begin{tabular}{|l|l|}
\hline Primeira Tricotomia & Segunda Tricotomia \\
\hline Quali signo: riscos na parede & Ícone:seta \\
\hline Sin signo: frase em cor azul e uma & Índice: Feita de forma livre e com pincel. \\
\hline Legi signo: Frase " Saudades virou & Símbolo: frase "Saudades virou a esquina" = \\
a esquina" com uma seta da direita & é um trocadilho já que Brasília não possui \\
para a esquerda e fazendo um traço & esquina pelo formato do seu projeto; \\
para baixo indicando o formato de & $\begin{array}{l}\text { desenho de seta = indicando esquina, } \\
\text { uma esquina }\end{array}$ \\
\hline
\end{tabular}

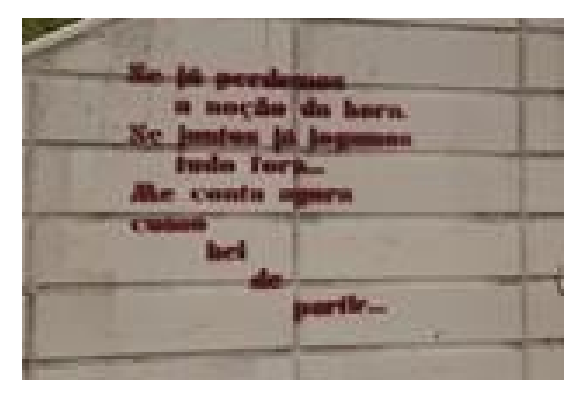

Figura 27 Quadra 104/105, Asa Sul

Autora: a pesquisadora

"Se já perdemos a noção da hora. Se juntos já jogamos tudo fora... Me conta agora como hei de partir..."

\begin{tabular}{|l|l|}
\hline Primeira Tricotomia & Segunda Tricotomia \\
\hline Quali signo: riscos na parede & Ícone: \\
\hline Sin signo: frase em cor vermelha & Índice:Técnica de stencil. \\
no muro & \\
\hline Legi signo: frase "Se já & Símbolo: A frase "Se já perdemos a noção da \\
perdemos a noção da hora. Se & hora. Se juntos já jogamos tudo fora... Me conta \\
juntos já jogamos tudo fora... Me & agora como hei de partir..." = verso da música \\
conta agora como hei de partir..." & "Eu te amo" de Chico Buarque; letra cursiva = \\
em muro de passarela & letra desenhada, cuidado estético, estruturada \\
subterrânea e em cor vermelho & de forma que cria movimento de leitura. \\
\hline
\end{tabular}




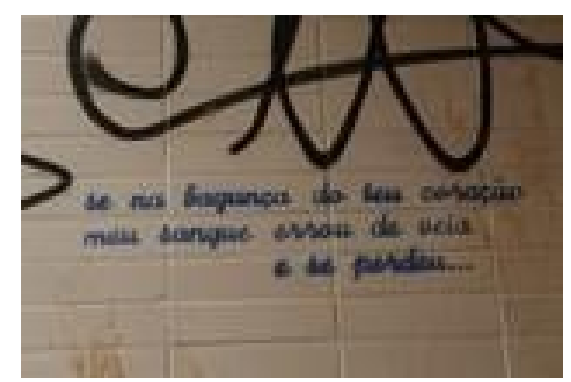

Figura 28 Quadra 104/105, Asa Sul Autora: a pesquisadora

"se na bagunça do teu coração meu sangue errou de veia e se perdeu..."

\begin{tabular}{|l|l|}
\hline Primeira Tricotomia & Segunda Tricotomia \\
\hline Quali signo: riscos na parede & ĺcone: \\
\hline Sin signo: frase em cor azul & Índice: Técnica a mão livre e pincel. \\
\hline Legi signo: Frase "se na bagunça & Símbolo: A frase "se na bagunça do teu \\
do teu coração meu sangue errou & coração meu sangue errou de veia e se \\
de veia e se perdeu..." em cor azul & perdeu..." = a frase que também é verso da \\
e em muro de passarela & $\begin{array}{l}\text { música "Eu te amo" de Chico Buarque, } \\
\text { remete a rejeição de um amor devido ao } \\
\text { subterrânea. }\end{array}$ \\
percurso sanguíneo nas veias do coração; \\
letra cursiva= cuidado estético, delicadeza.
\end{tabular}

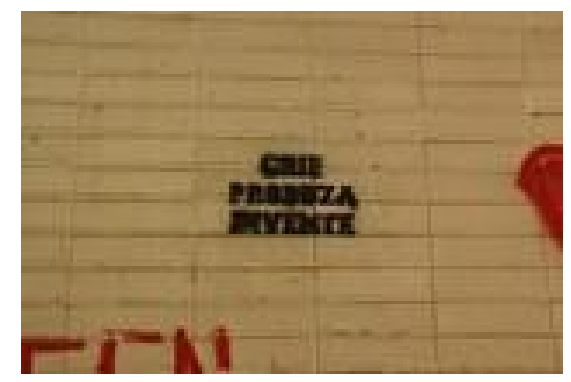

Figura 29 Quadra 104/105, Asa Sul Autora: a pesquisadora

\begin{tabular}{|l|l|}
\hline Primeira Tricotomia & Segunda Tricotomia \\
\hline $\begin{array}{l}\text { Quali signo: mancha } \\
\text { escura }\end{array}$ & Ícone: \\
\hline $\begin{array}{l}\text { Sin signo: palavra soltas } \\
\text { em muro }\end{array}$ & Índice: Técnica stencil. \\
\hline
\end{tabular}




\begin{tabular}{|c|c|}
\hline $\begin{array}{l}\text { Legi signo: As palavra crie, } \\
\text { produza e invente uma em } \\
\text { baixo da outra em cor } \\
\text { preta. }\end{array}$ & $\begin{array}{l}\text { Simbolo: As palavras crie, produza e Invente = todas } \\
\text { no imperativo que tem como função verbal propor uma } \\
\text { ideia, ordem ou ação, palavras provocadoras de ação } \\
\text { e inspiração. }\end{array}$ \\
\hline
\end{tabular}

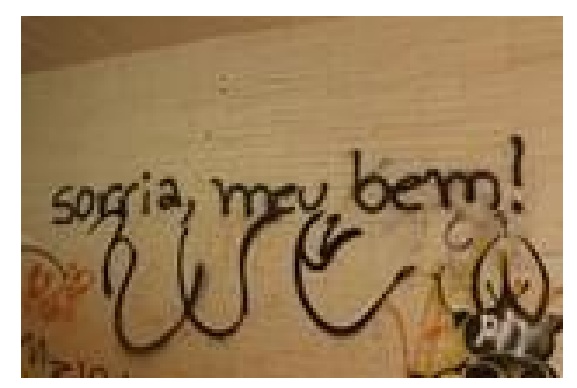

Figura 30 Quadra 104/105, Asa Sul Autora: a pesquisadora

\begin{tabular}{|c|c|}
\hline Primeira Tricotomia & Segunda Tricotomia \\
\hline Quali signo: risco preto & Ícone: \\
\hline $\begin{array}{l}\text { Sin signo: frase em cor preta } \\
\text { em muro de passagem } \\
\text { subterrânea. }\end{array}$ & Índice:Técnica traço livre com spray. \\
\hline $\begin{array}{l}\text { Legi signo: frase" sorria, meu } \\
\text { bem!" }\end{array}$ & $\begin{array}{l}\text { Símbolo: frase "sorria, meu bem!" = motiva a } \\
\text { sempre sorrir e com uma chamada carinhosa "meu } \\
\text { bem"; letra cursiva: delicadeza, cuidado estético. }\end{array}$ \\
\hline
\end{tabular}

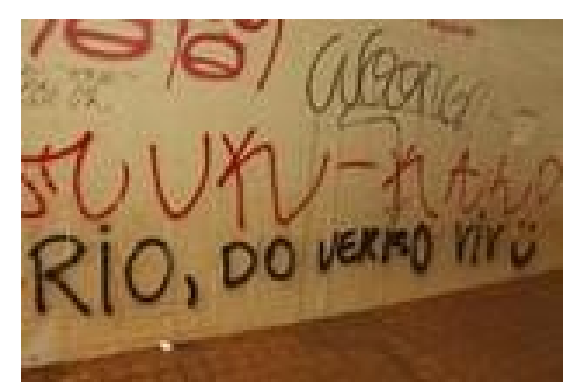

Figura 31Quadra 104/105, Asa Sul Autora: a pesquisadora 


\begin{tabular}{|l|l|}
\hline Primeira Tricotomia & Segunda Tricotomia \\
\hline Quali signo: riscos coloridos & Ícone: \\
\hline Sin signo: frase em muro & Índice: Técnica traço livre com spray. \\
\hline Legi signo: frase "rio, do verbo & Símbolo: frase "rio, do verbo viv (:)" = relação de \\
viv @)" está em muro e bem & vitalidade que o rio proporciona aos seres vivos; \\
embaixo perto do chão em & emotiom feliz = felicidade, satisfação. \\
letras grandes e de grande \\
extensão.
\end{tabular}

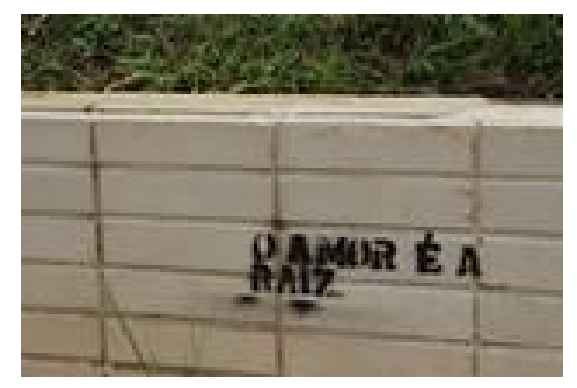

Figura 32 Quadra 104/105, Asa Sul Autora: a pesquisadora

\begin{tabular}{|l|l|}
\hline Primeira Tricotomia & Segunda Tricotomia \\
\hline $\begin{array}{l}\text { Quali signo: mancha } \\
\text { escura. }\end{array}$ & Ícone: \\
\hline $\begin{array}{l}\text { Sin signo: frase em cor } \\
\text { preta em fundo branco. }\end{array}$ & Índice: Técnica de stencil. \\
\hline $\begin{array}{l}\text { Legi signo: frase "o amor } \\
\text { é a raiz" em muro da } \\
\text { passarela subterrânea na } \\
\text { cor preta. }\end{array}$ & $\begin{array}{l}\text { Símbolo: Frase "o amor é a raiz" = está no roda pé, } \\
\text { pessoas abaixema dos olhos e para ler é preciso que às } \\
\text { é a raiz, a base que estrutura as relações humanas. }\end{array}$ \\
\hline
\end{tabular}




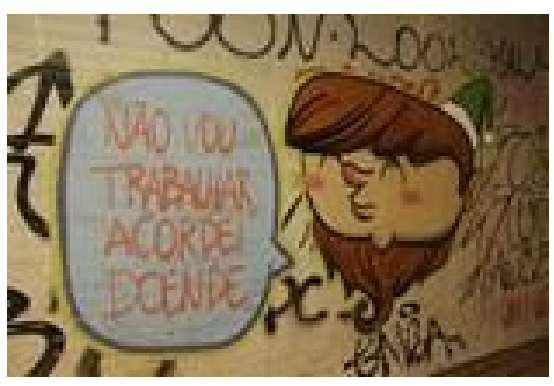

Figura 33 Quadra 104/105, Asa Sul Autora: a pesquisadora

\begin{tabular}{|c|c|}
\hline Primeira Tricotomia & Segunda Tricotomia \\
\hline Quali signo: manchas coloridas & Ícone: duende, gorro, cabelo \\
\hline $\begin{array}{l}\text { Sin signo: balão de diálogo e } \\
\text { desenho representando um } \\
\text { duende. }\end{array}$ & Índice: Técnica de spray. \\
\hline $\begin{array}{l}\text { Legi signo: Balão de diálogo com a } \\
\text { frase "Não vou trabalhar, acordei } \\
\text { doende." Com fundo em cor azul e } \\
\text { a frase escrita em cor laranja e o } \\
\text { desenho de um duende ao lado } \\
\text { com os olhos fechados com feição } \\
\text { feliz. }\end{array}$ & $\begin{array}{l}\text { Símbolo: frase "Não vou trabalhar, acordei } \\
\text { doende." = trocadilho da palavra doende e } \\
\text { doente que é a justificativa da ausência no } \\
\text { trabalho; duende = ser lendário, travesso, } \\
\text { feição facial feliz e contente. }\end{array}$ \\
\hline
\end{tabular}

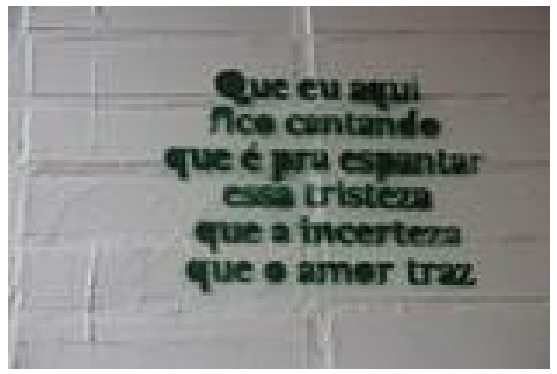

Figura 34 Quadra 102/103, Asa Sul Autora: a pesquisadora 


\begin{tabular}{|l|l|}
\hline Primeira Tricotomia & Segunda Tricotomia \\
\hline Quali signo:macha escura & Ícone: \\
\hline $\begin{array}{l}\text { Sin signo: frase em cor escura em } \\
\text { fundo branco }\end{array}$ & $\begin{array}{l}\text { Índice: A frase "Que eu aqui fico cantando } \\
\text { que é pra espantar essa tristeza que a } \\
\text { incerteza que o amor traz" feita com a } \\
\text { técnica de stencil e na cor verde escuro. }\end{array}$ \\
\hline $\begin{array}{l}\text { Legi signo: frase "Que eu aqui fico } \\
\text { cantando que é pra espantar essa } \\
\text { tristeza que a incerteza que o amor } \\
\text { traz" em cor verde escuro com a } \\
\text { técnica de stencil no muro da passarela } \\
\text { subterrânea. }\end{array}$ & $\begin{array}{l}\text { incerteza que pra espantar essa tristeza que a amor traz" } \\
\text { reprentação das relações humanas, } \\
\text { incerteza que é amar outra pessoa, amor } \\
\text { não correspondido; cor verde escuro = } \\
\text { esperança, plenitude. }\end{array}$ \\
\hline
\end{tabular}

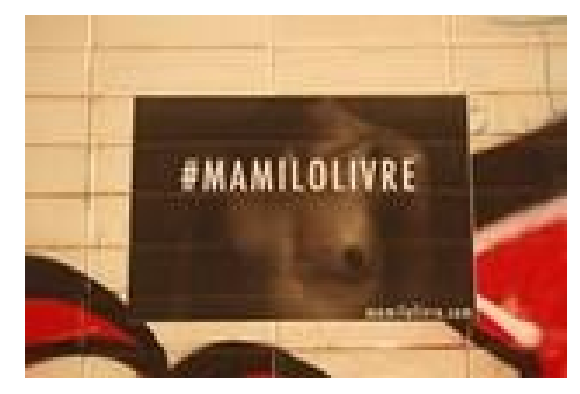

Figura 35 Quadra 102/103, Asa Sul

Autora: a pesquisadora

\begin{tabular}{|l|l|}
\hline Primeira Tricotomia & Segunda Tricotomia \\
\hline Quali signo: mancha escura & Ícone: seio \\
\hline $\begin{array}{l}\text { Sin signo: quadrado escuro em fundo } \\
\text { branco }\end{array}$ & Índice: Técnica colagem. \\
\hline $\begin{array}{l}\text { Legi signo: colagem de um cartaz em } \\
\text { tons escuros com a imagem de um }\end{array}$ & $\begin{array}{l}\text { Símbolo: Cartaz colado na parede da } \\
\text { passagem subterrânea = informativo, }\end{array}$ \\
\hline
\end{tabular}




\begin{tabular}{|l|l|}
\hline corpo humano da parte abaixo do & divulgação; frase \#mamilolivre \\
pescoço e acima da cintura e os seios a & assinatura, movimento feminista que leva \\
mostra, com a frase \#mamilolivre em & para as ruas a discussão sobre igualdade \\
cor branca e em cima da imagem. & $\begin{array}{l}\text { de gênero; seio = fonte de alimento } \\
\text { materno, sexualidade feminina. }\end{array}$ \\
\hline
\end{tabular}




\section{Mapeamento de intervenções visuais nas passarelas da asa sul}
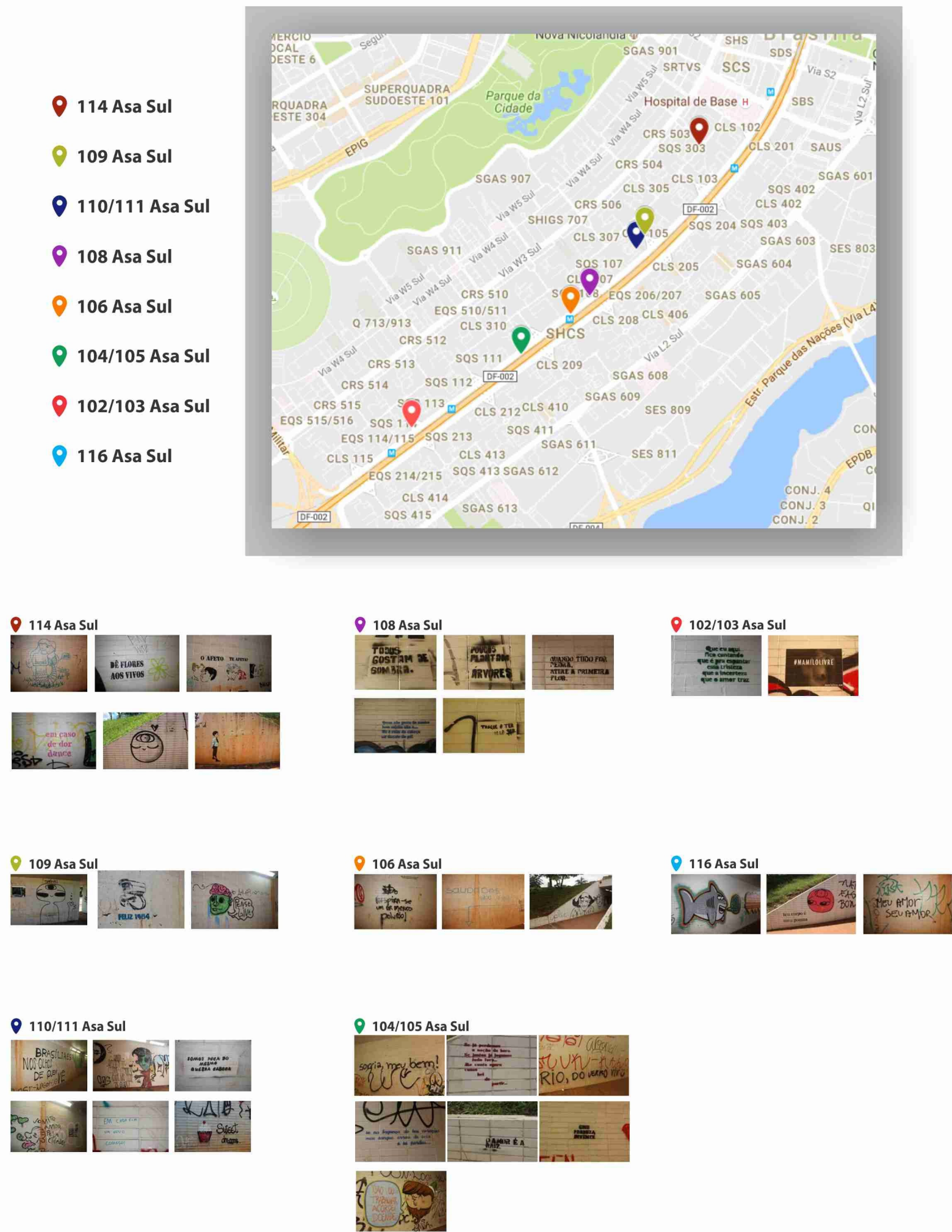


\section{Questionário "Mensagens pela (e pela) cidade"}

\author{
1- Gênero \\ Feminino ( ) \\ Masculino ( )

\section{2- Faixa Etária} \\ Até 12 anos ( ) \\ Entre 13 e 18 anos( ) \\ Entre 19 e 25 anos ( ) \\ Entre 26 e 40 anos ( ) \\ Mais de 40 anos ( )
}

\section{3- Escolaridade}

Ensino Fundamental incompleto( ) Ensino Fundamental completo ( )

Ensino Médio incompleto ( )

Ensino Médio completo ( )

Graduação incompleta ( )

Graduação completa ( )

Pós-graduação incompleta ( )

Pós-graduação completa ( )

\section{4- Motivo de transitar pelo local}

Ida ou volta do trabalho ( )

Ida ou volta da escola ou

faculdade ( )

Passeio ( )

Outro motivo ( )

5- Frequência que passa pelo local

Diariamente ( )

Duas ou mais vezes por dia ( )

2 a 3 vezes por semana ( )

Semanalmente ( )

De vez em quando ( )
6- Já percebera as

intervenções?

\author{
$\operatorname{Sim}($ ) \\ Não ( ) \\ Mais ou menos ( ) \\ 7- Já parou alguma vez \\ para observar melhor?
}

$\operatorname{Sim}($ )

Não ( )

Mais ou menos ( )

8- A impressão que tem sobre esse tipo de mensagem? (Cite 3 adjetivos)

\section{9- Alguma dessas} intervenções já Ihe chamou a atenção? Por quê?

Sim ( ) Não ( )

Motivo:

10- Lhe parece que esse tipo de mensagem pode ajudar a promover o afeto e ou a reflexão para a melhora da vida em sociedade? Por quê? 
Quadra 116, Asa Sul.
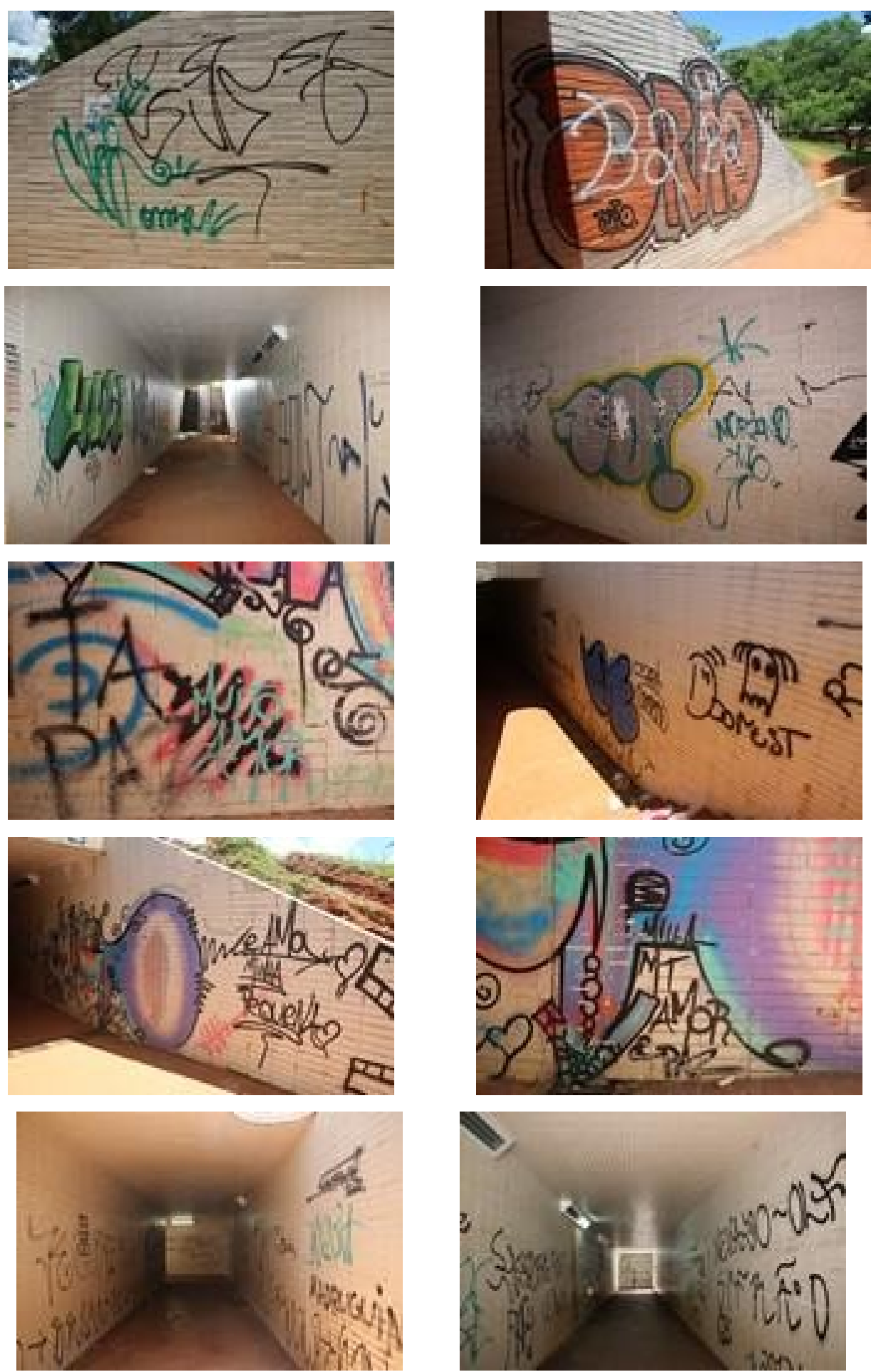

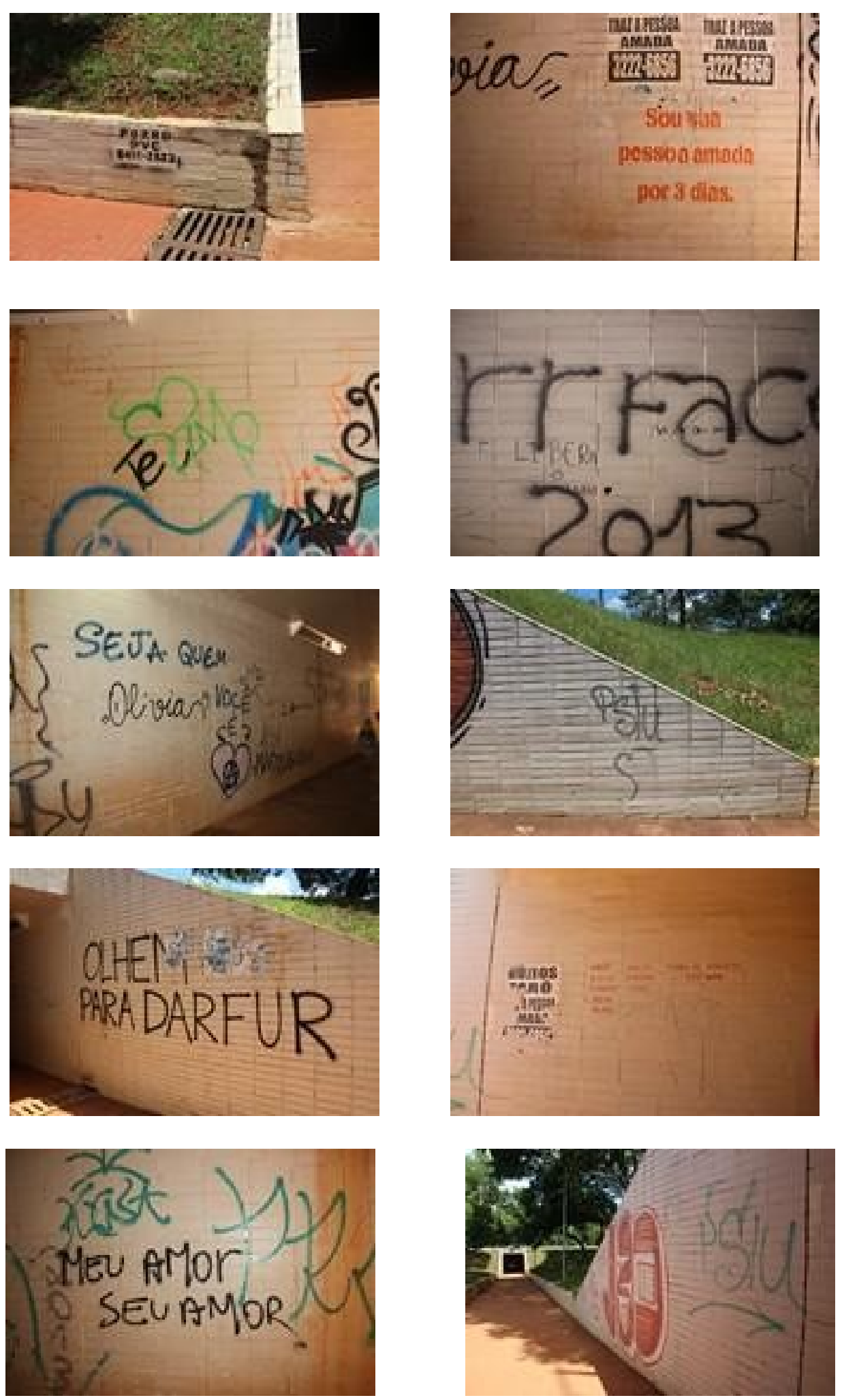

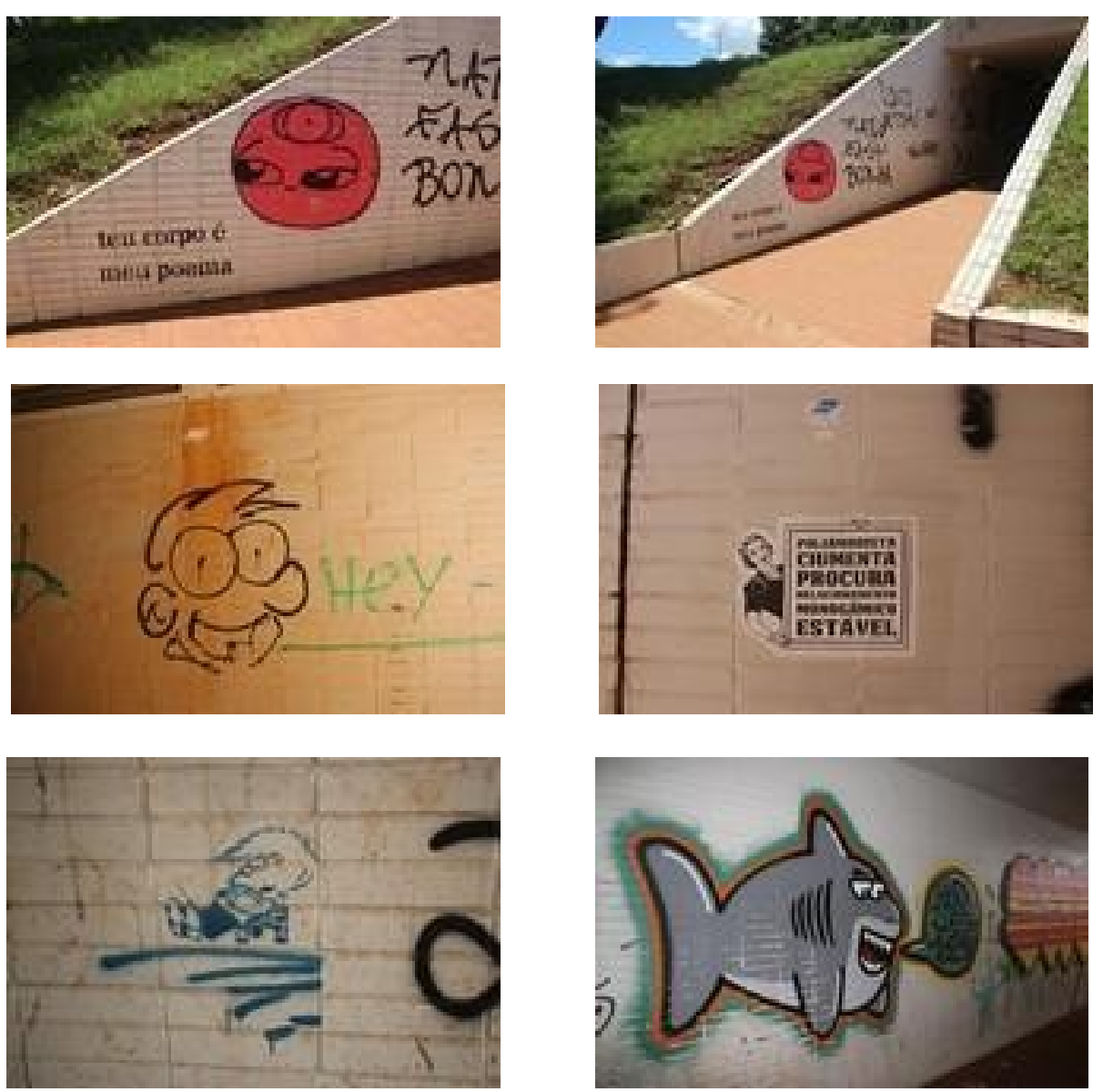

Quadra 114, Asa Sul
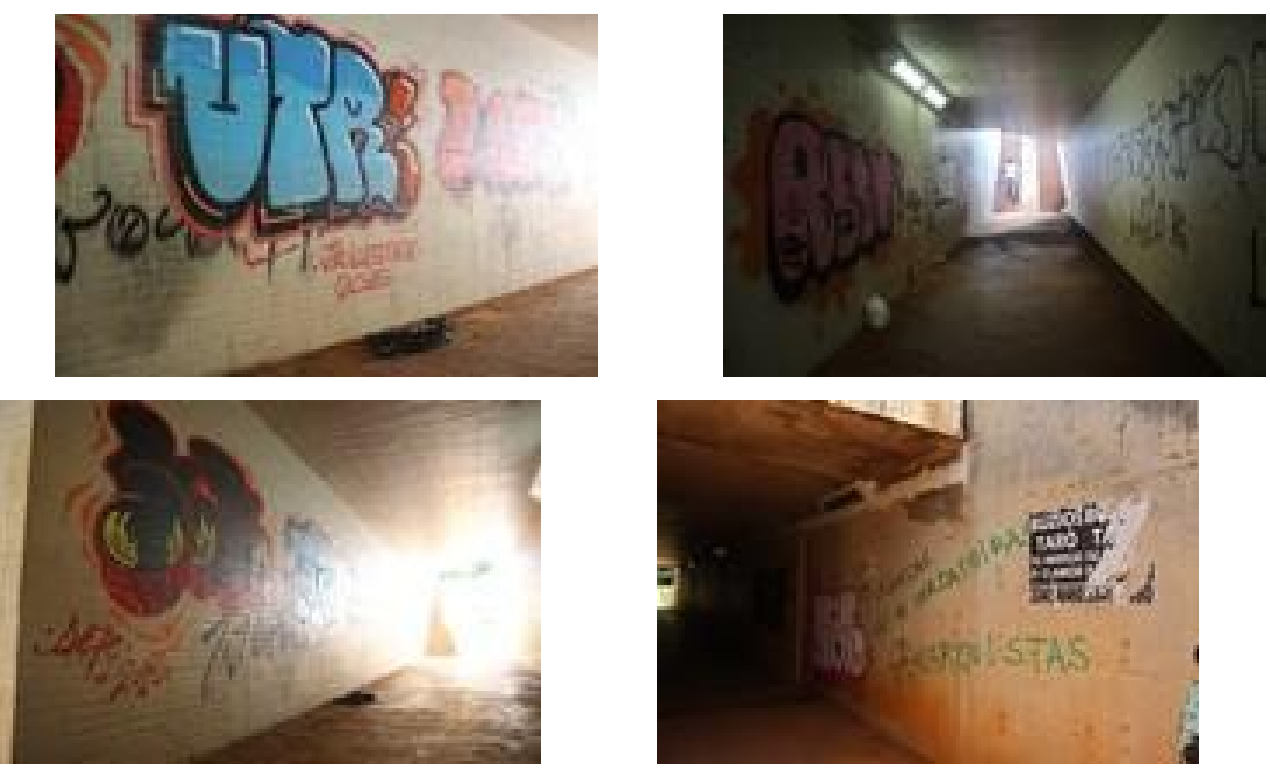

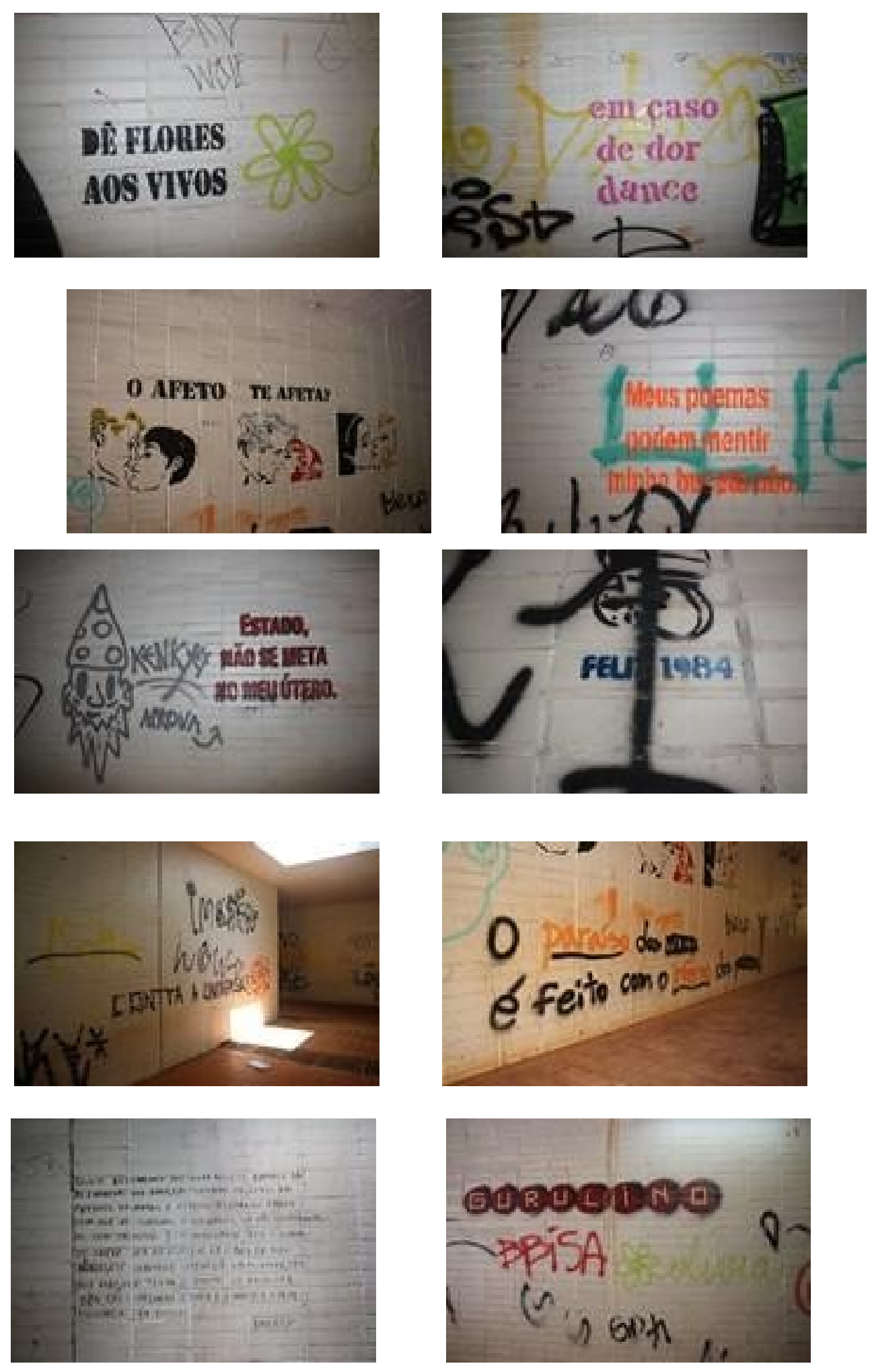

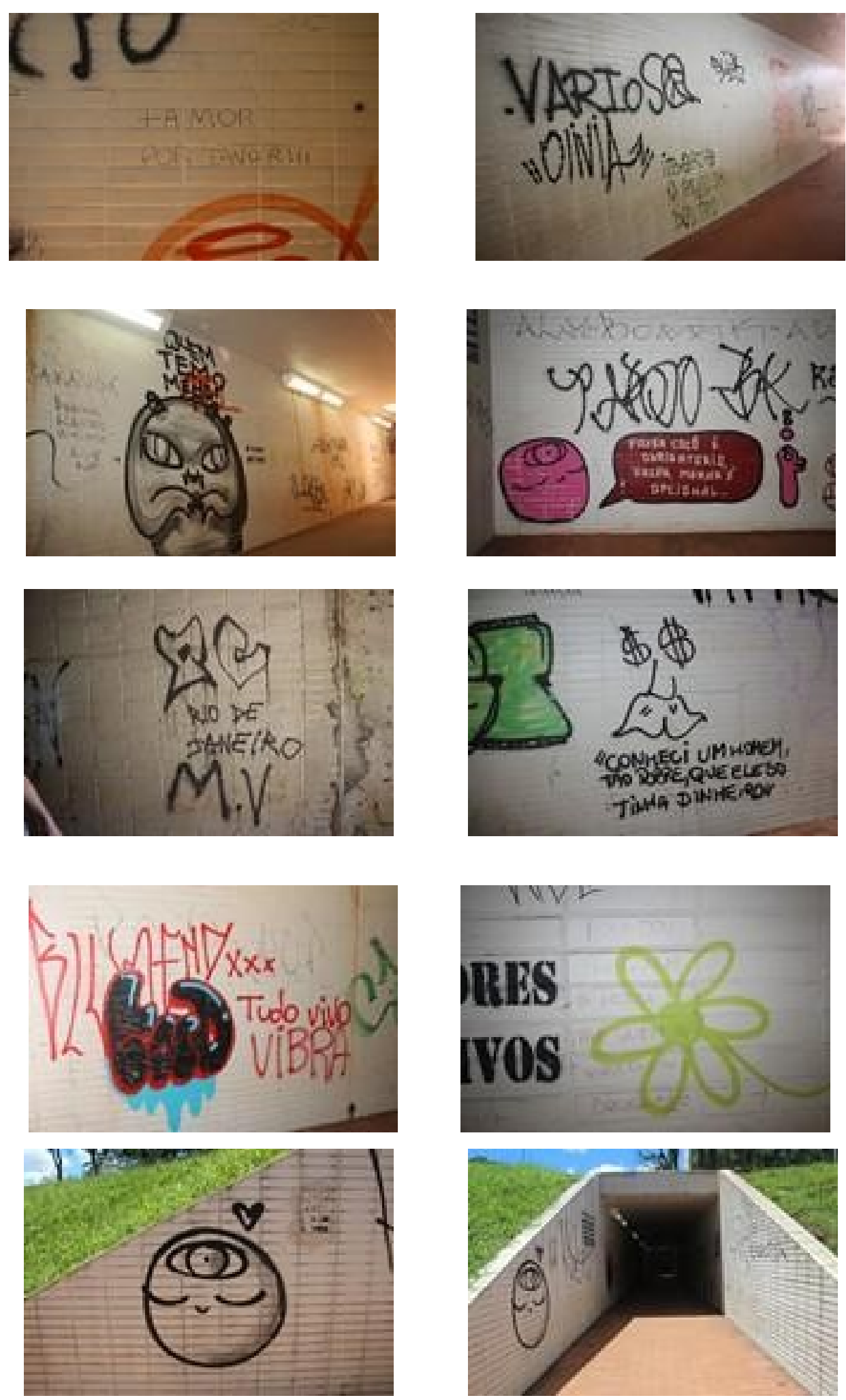

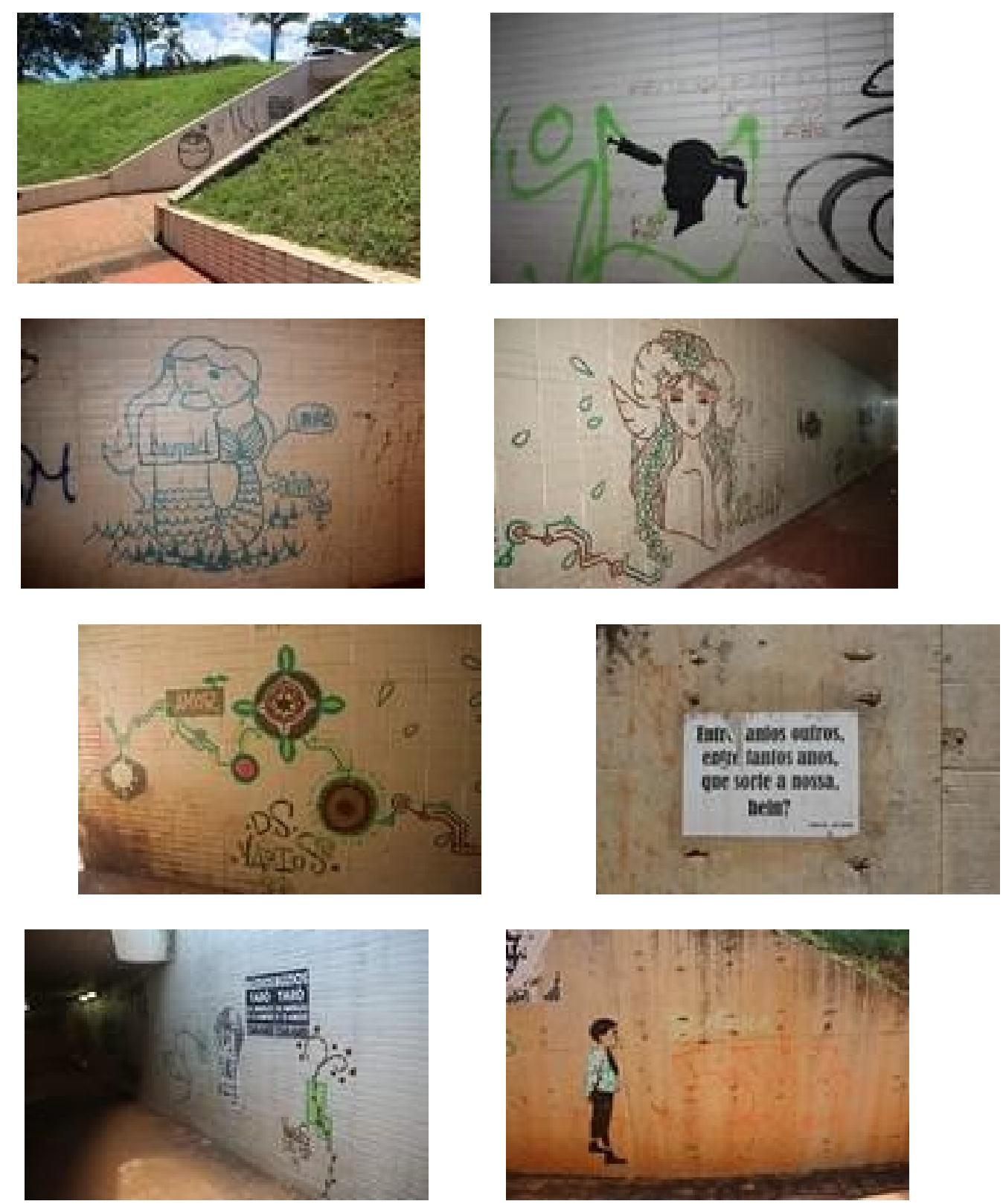

Quadra 112, Asa Sul
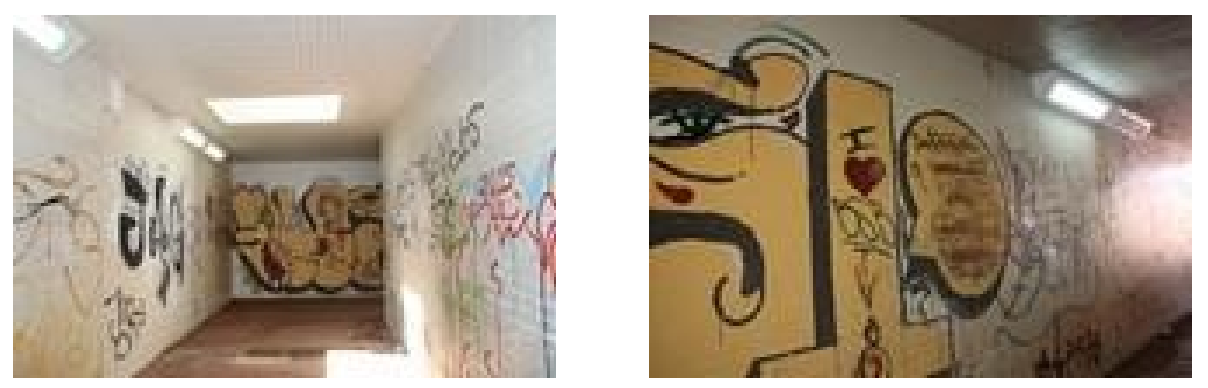

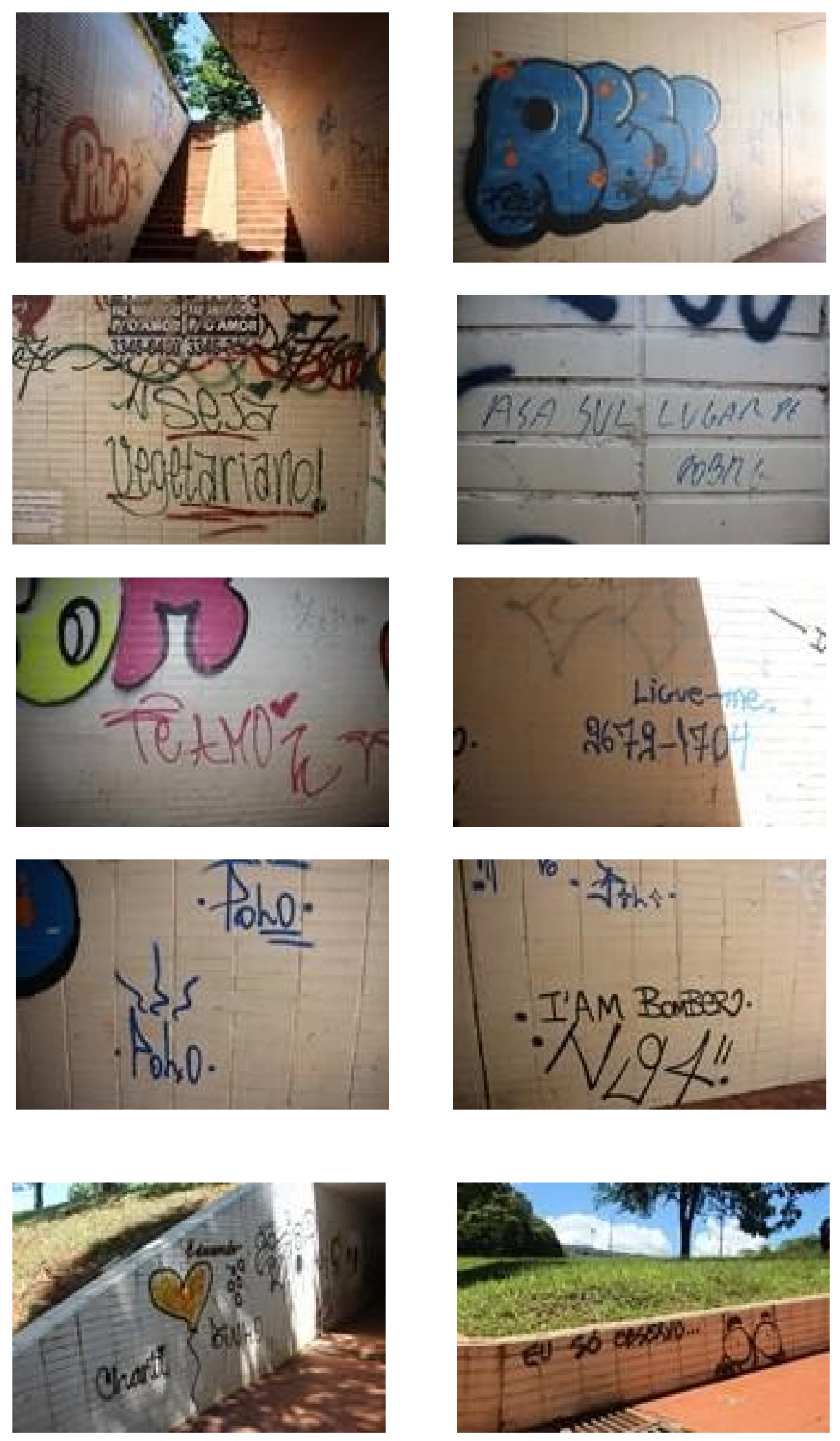

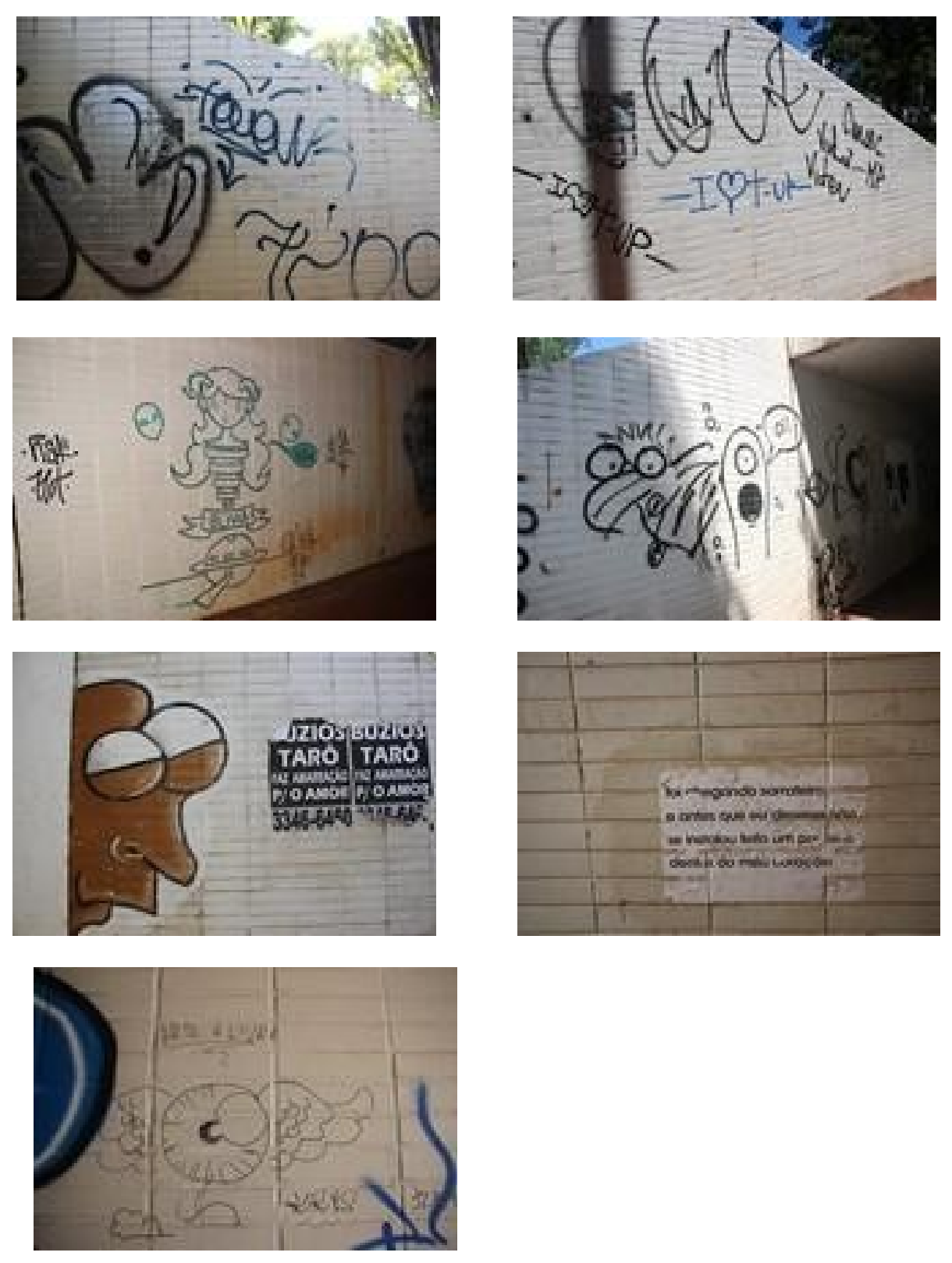

Quadra 109, Asa Sul
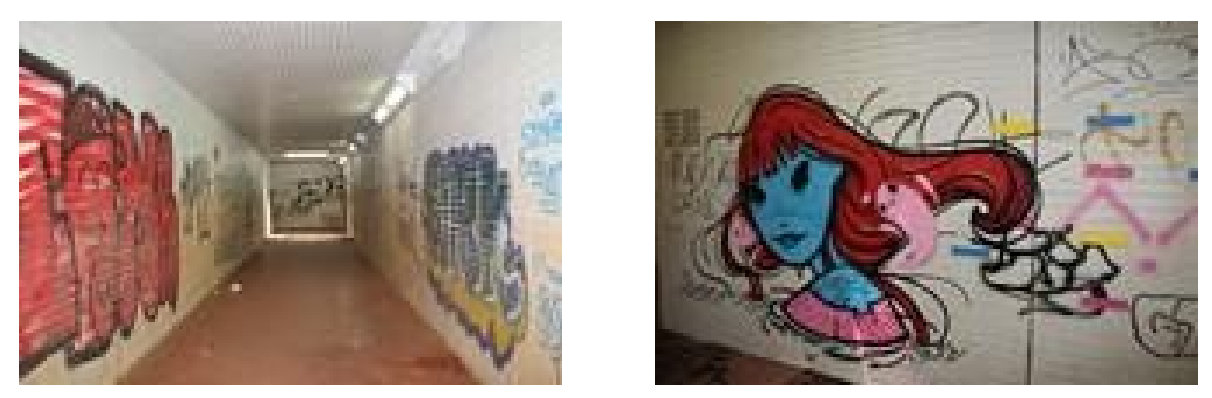

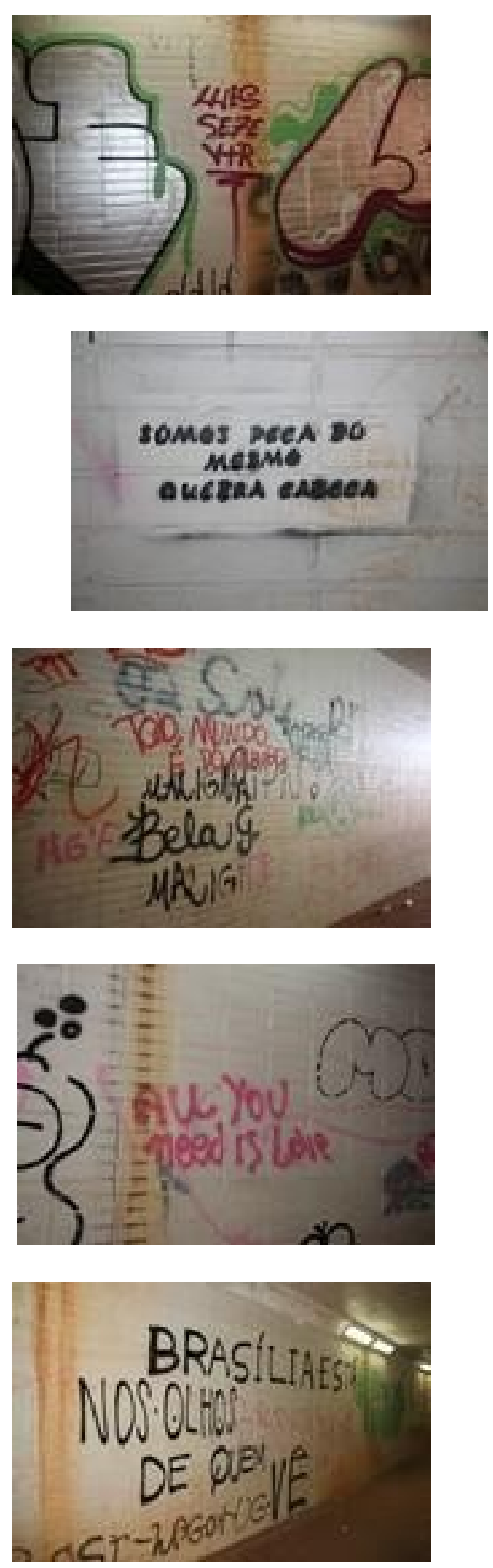
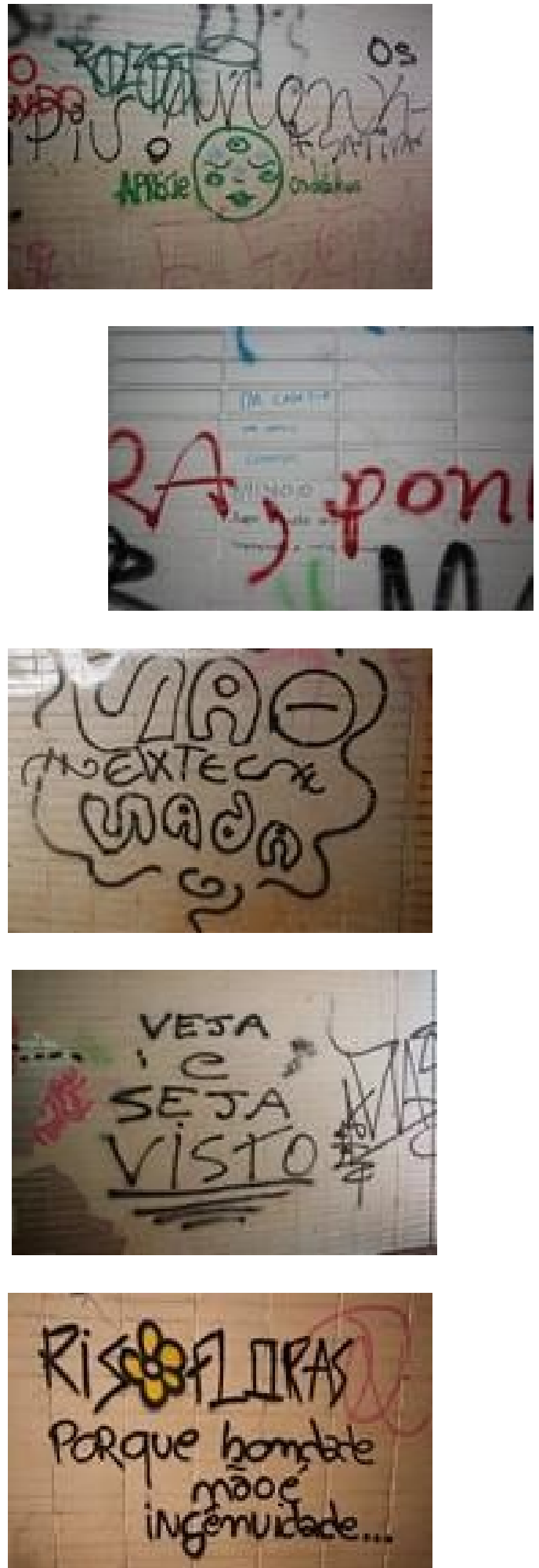

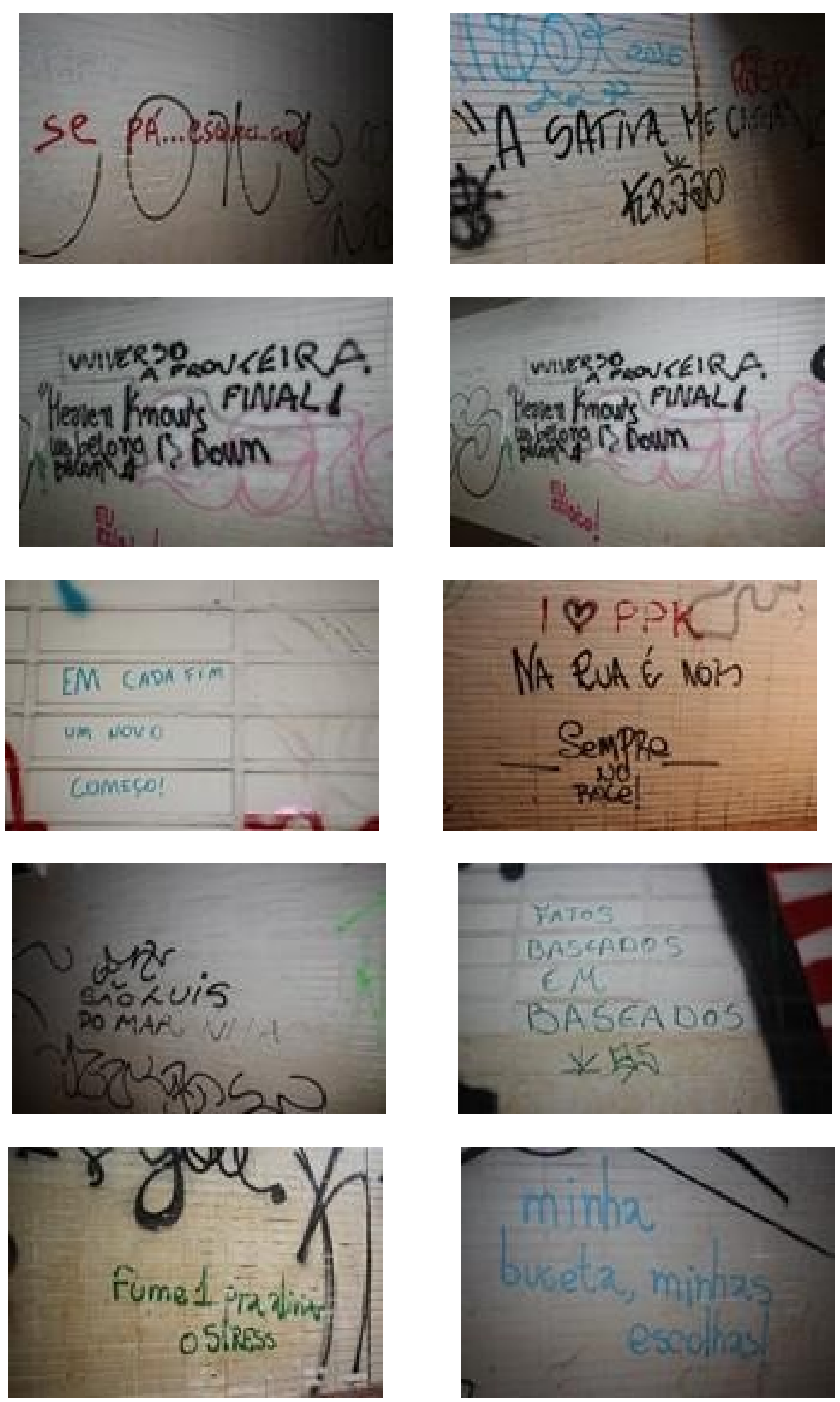

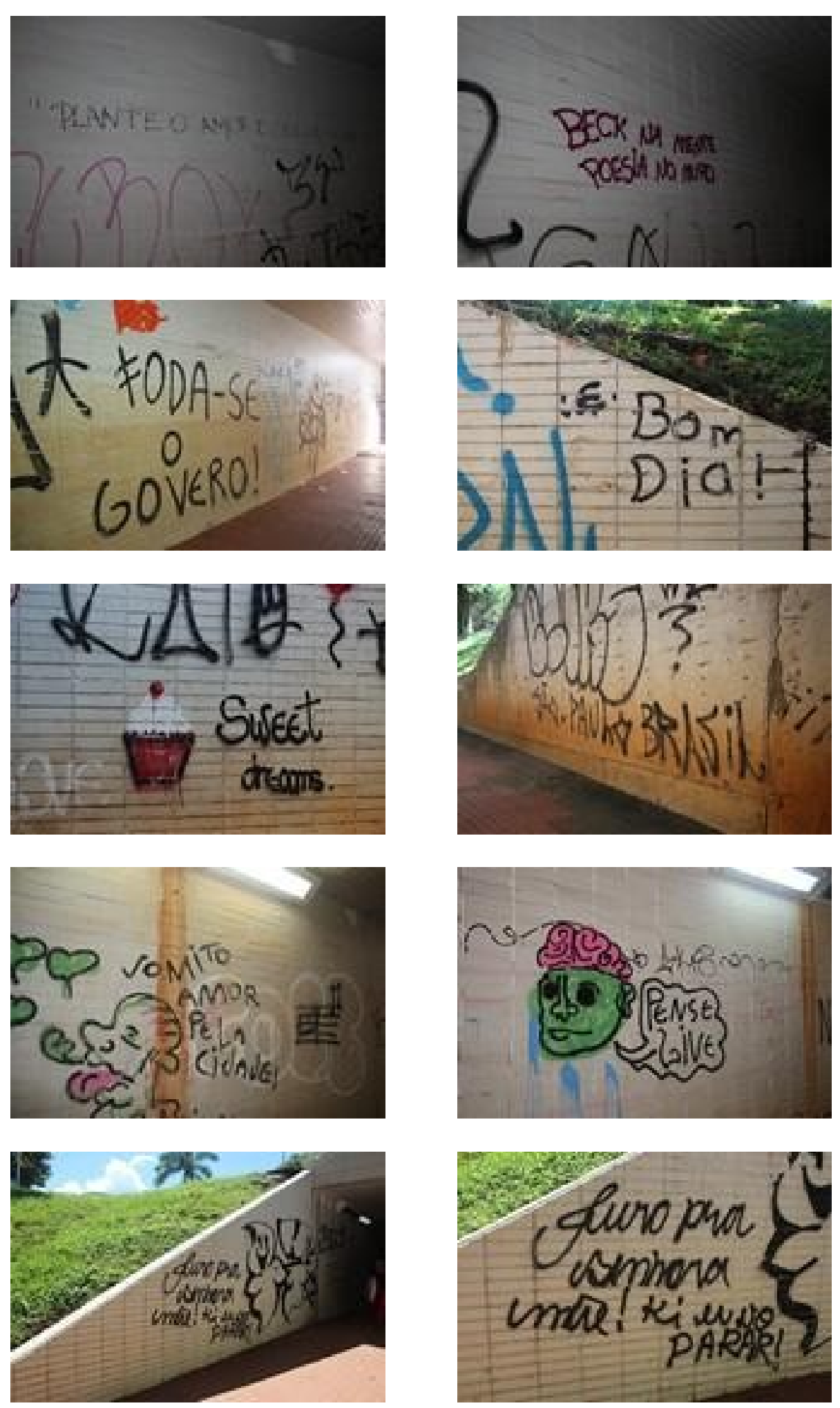

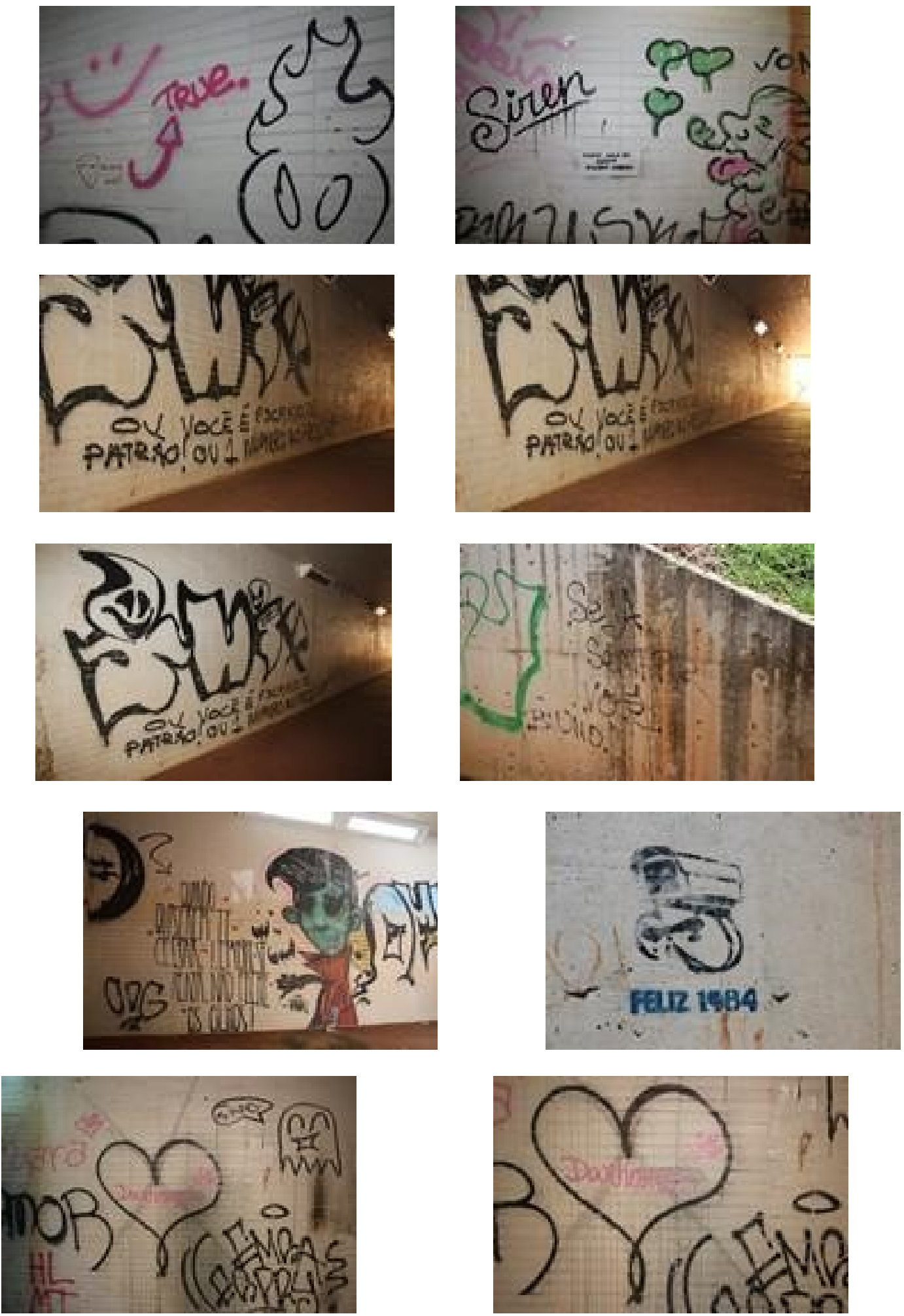

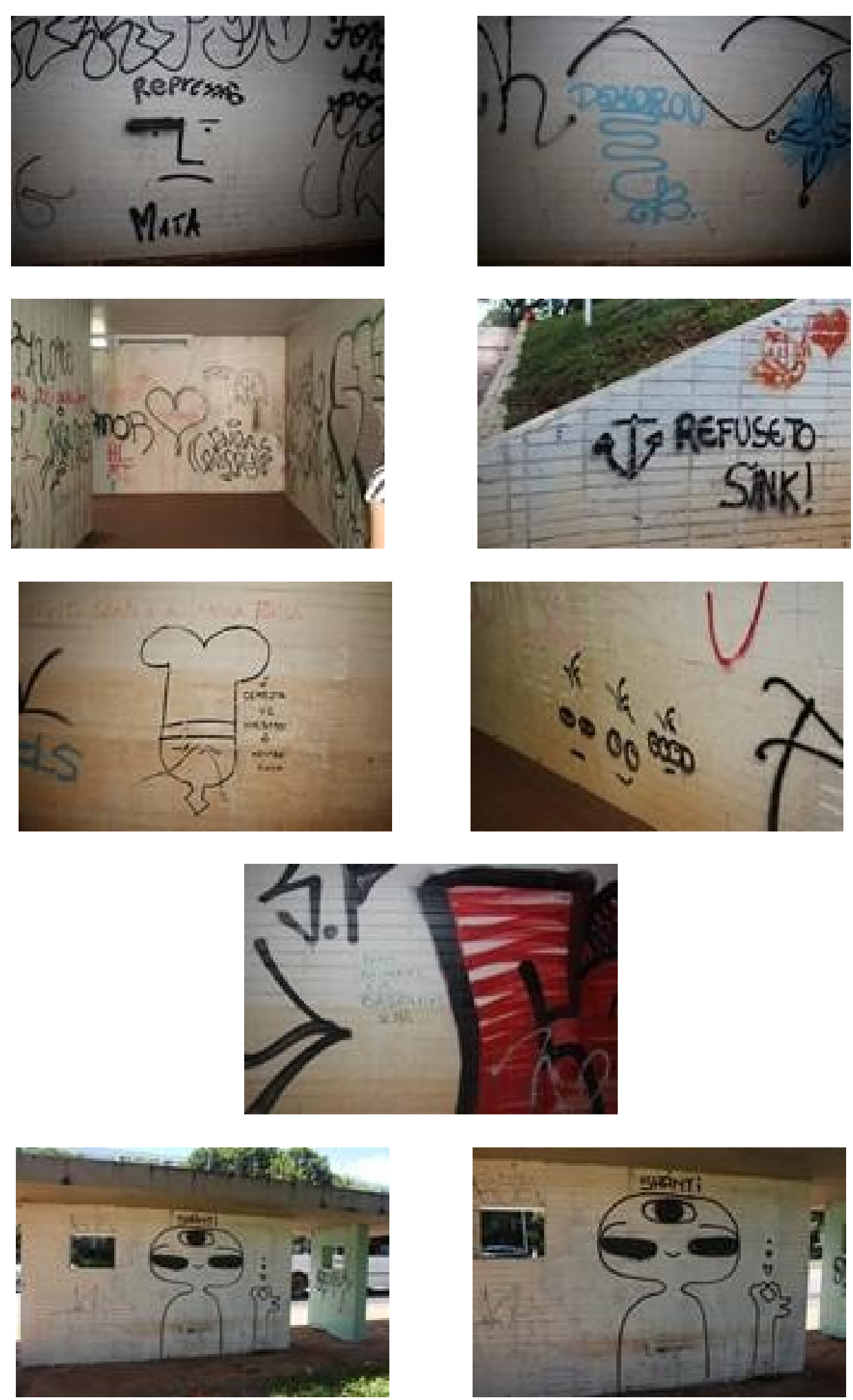

Quadra 108, Asa Sul 

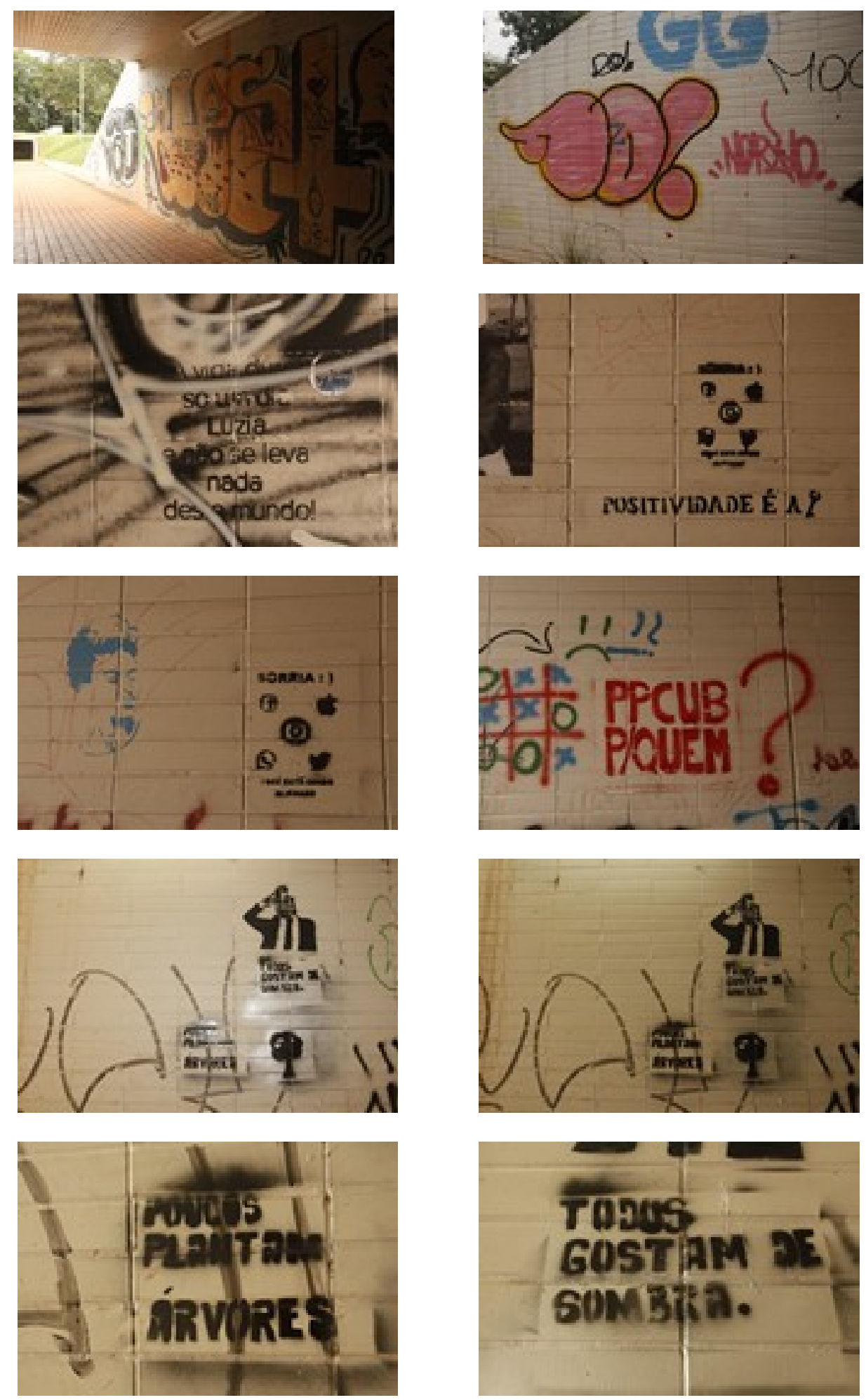

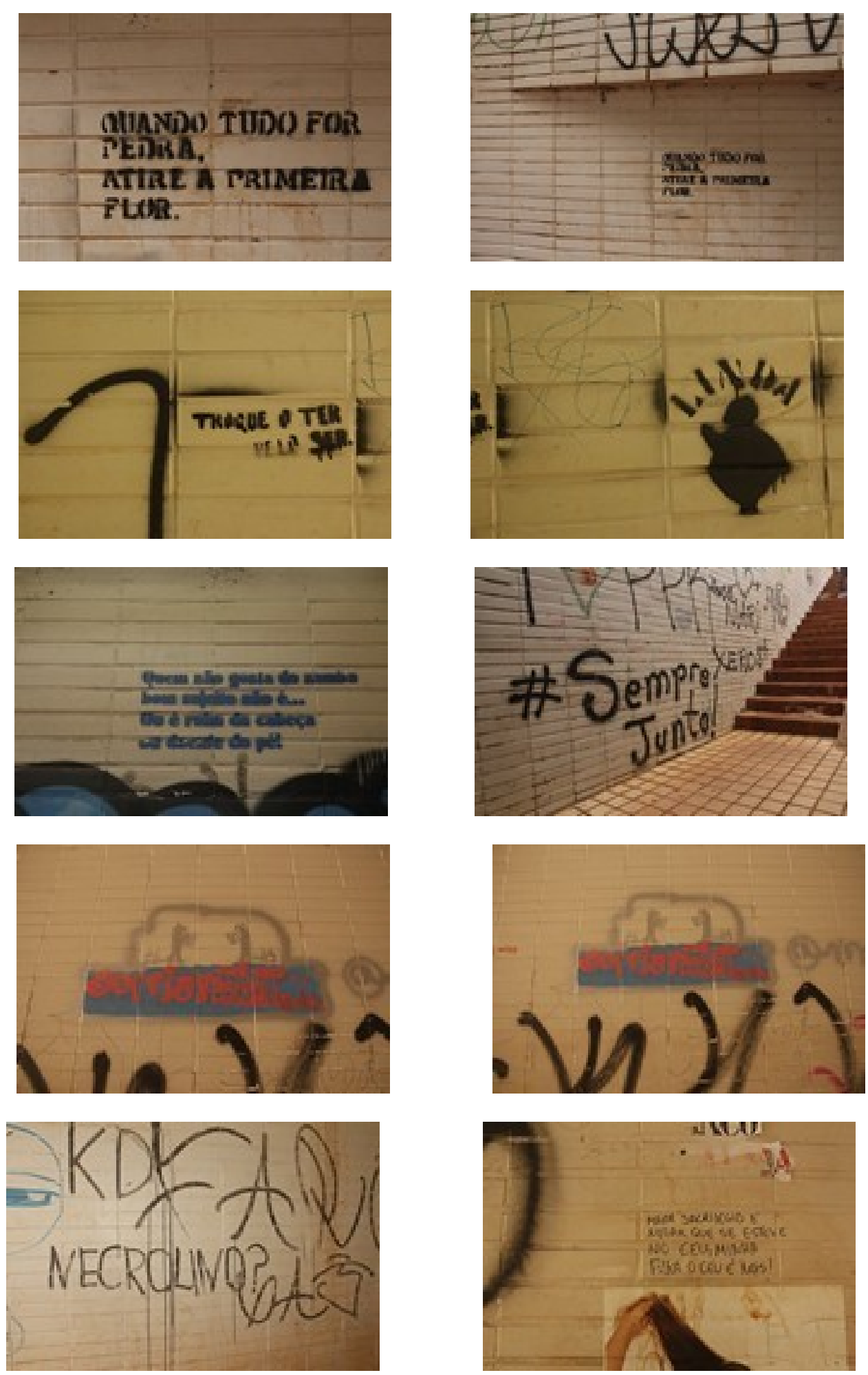

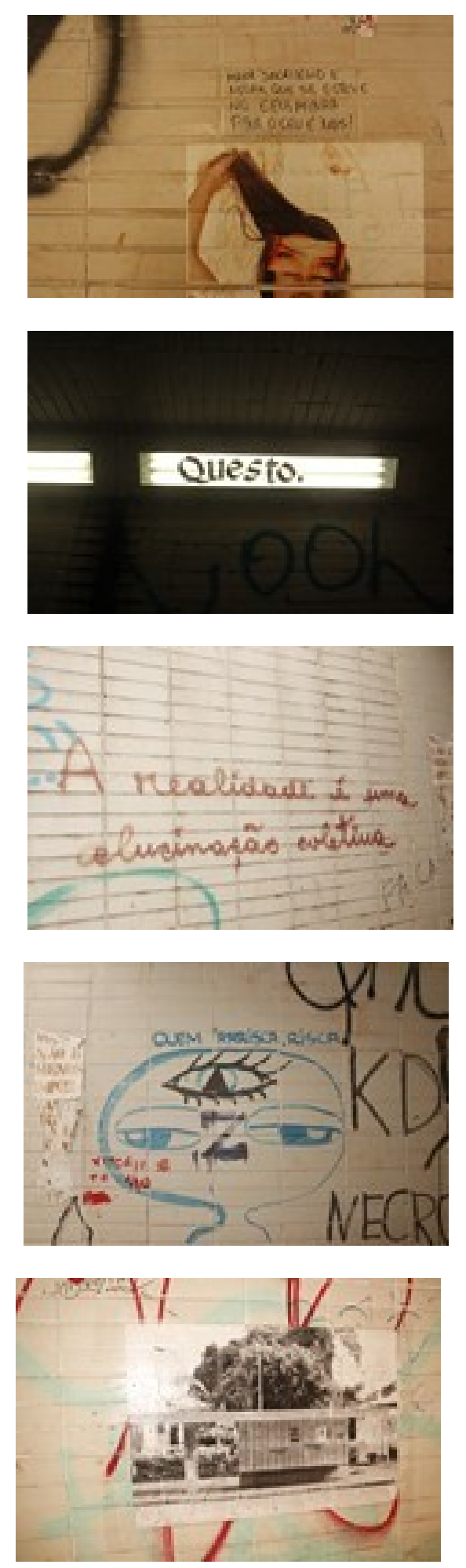

Quadra 106, Asa Sul
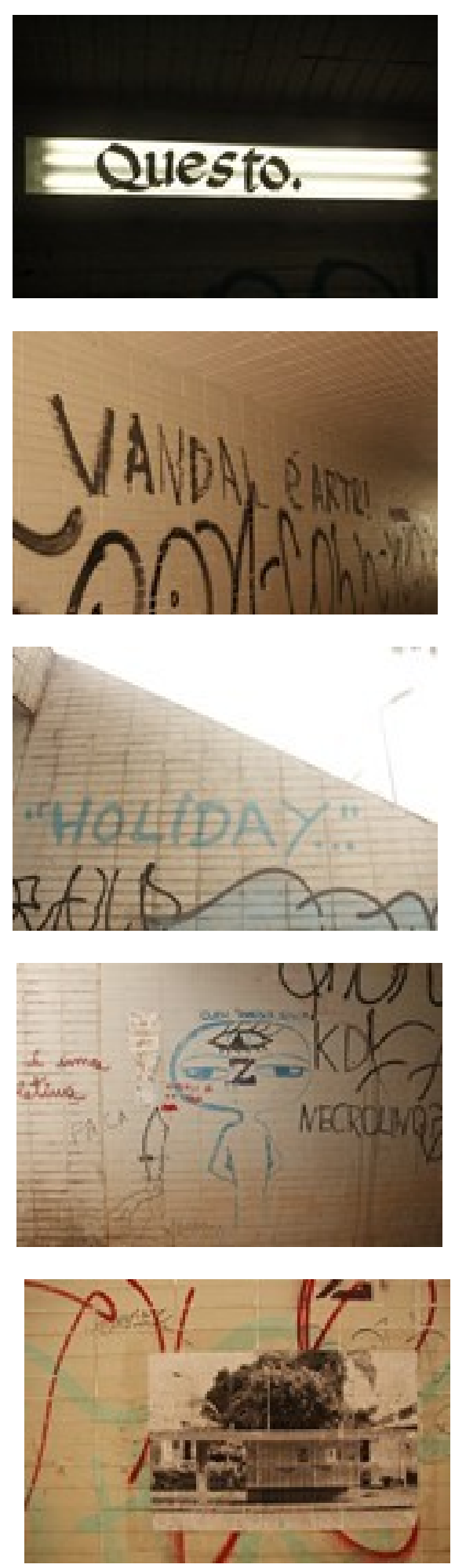

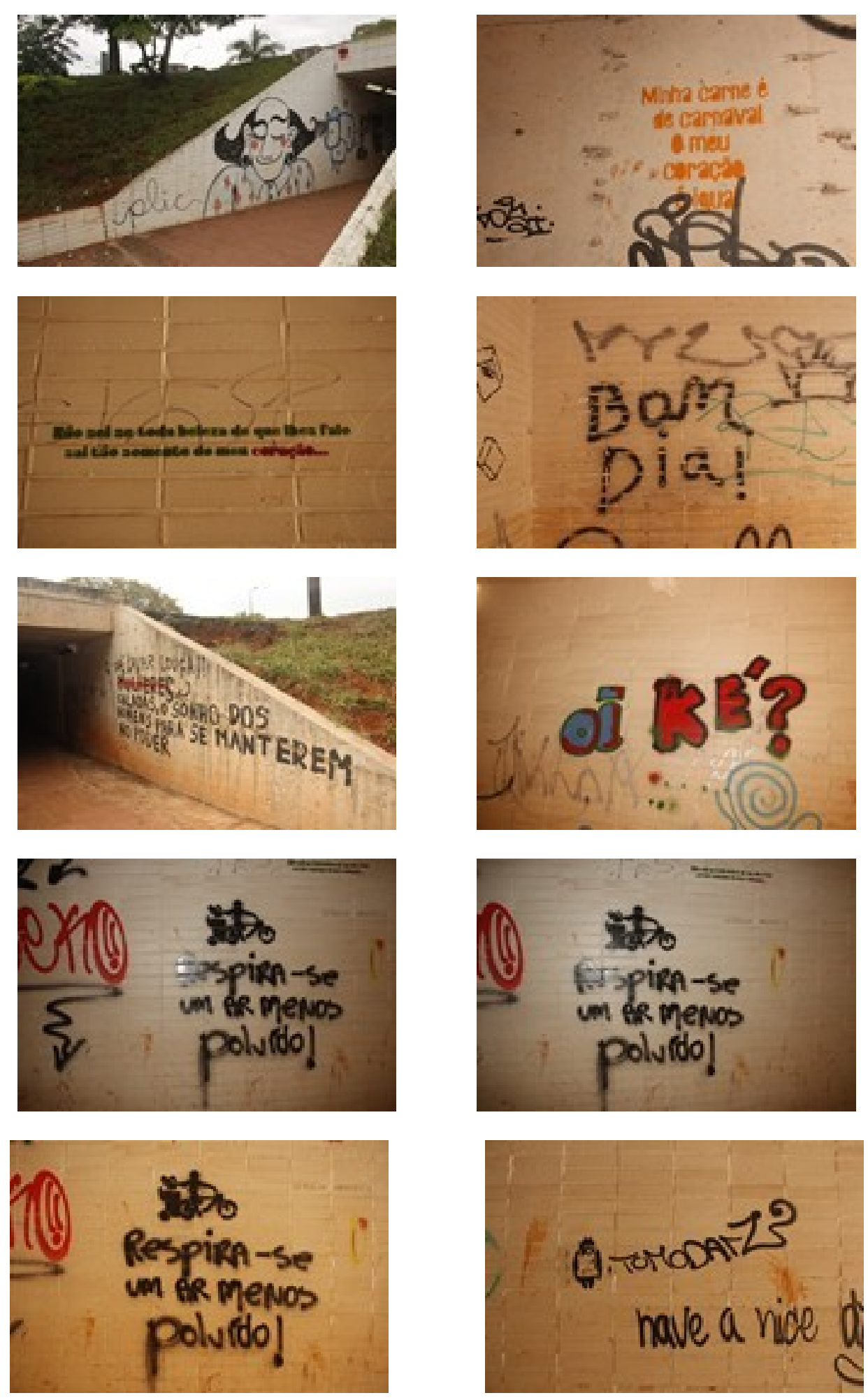

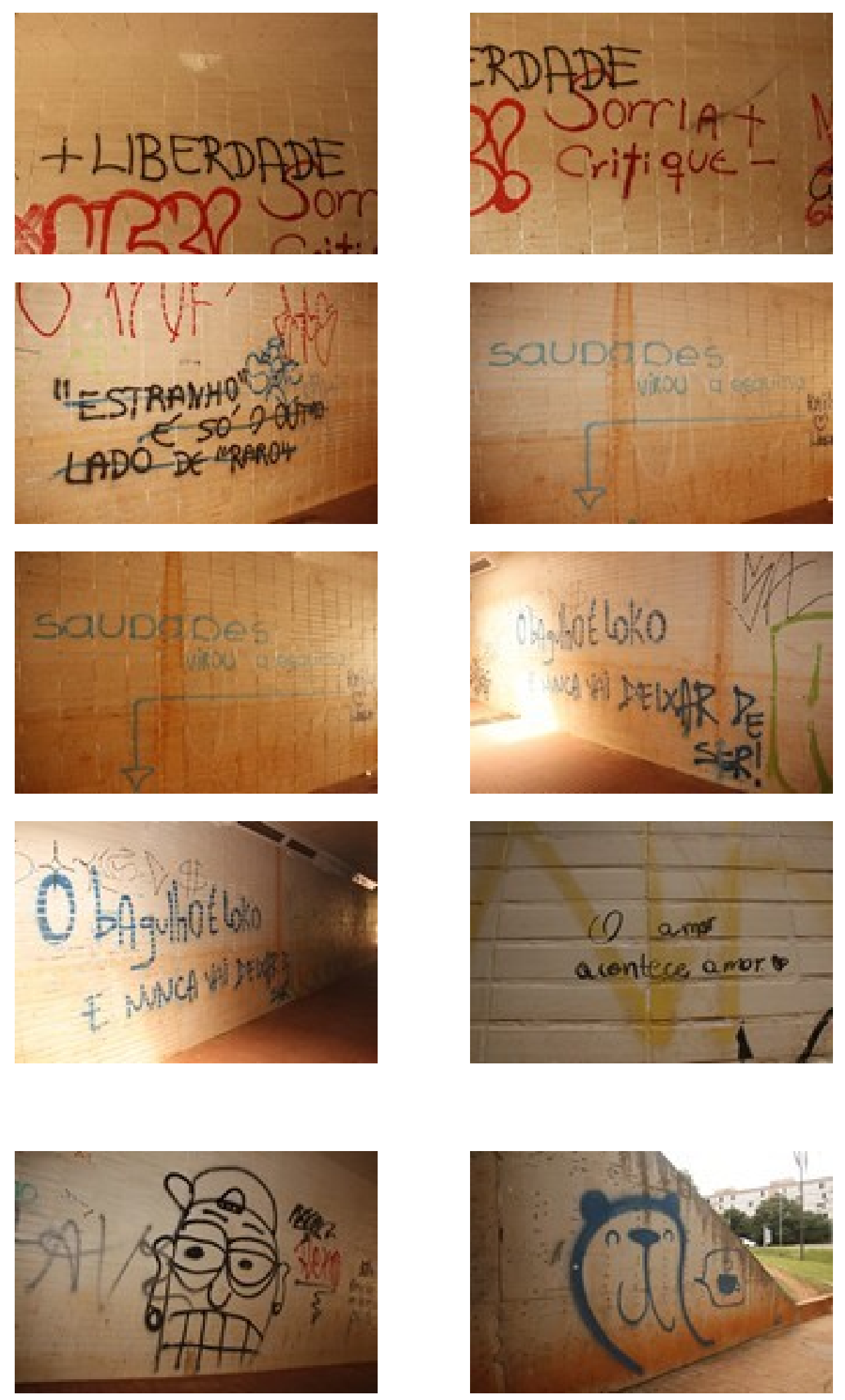

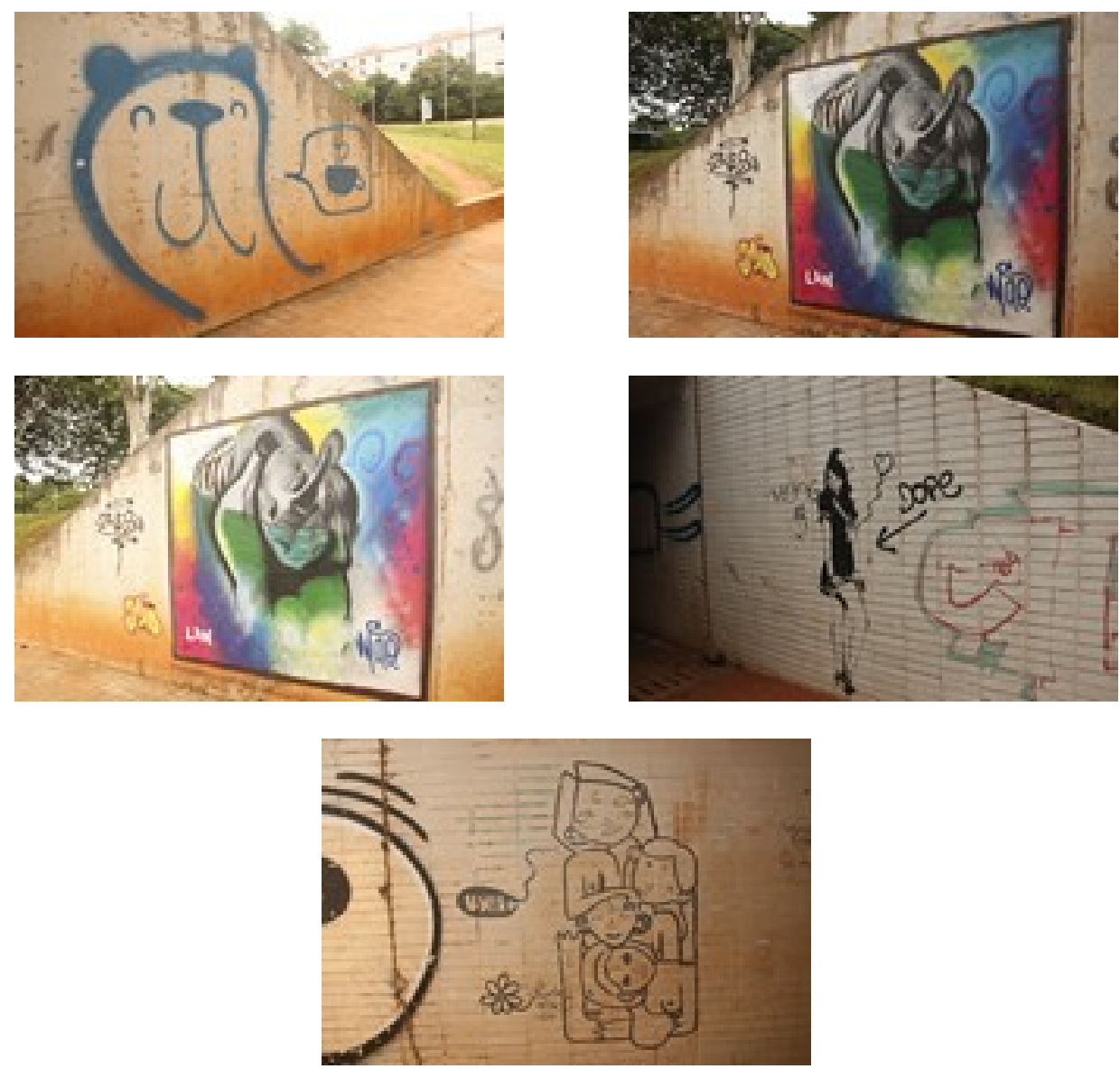

Quadra 104/105, Asa Sul
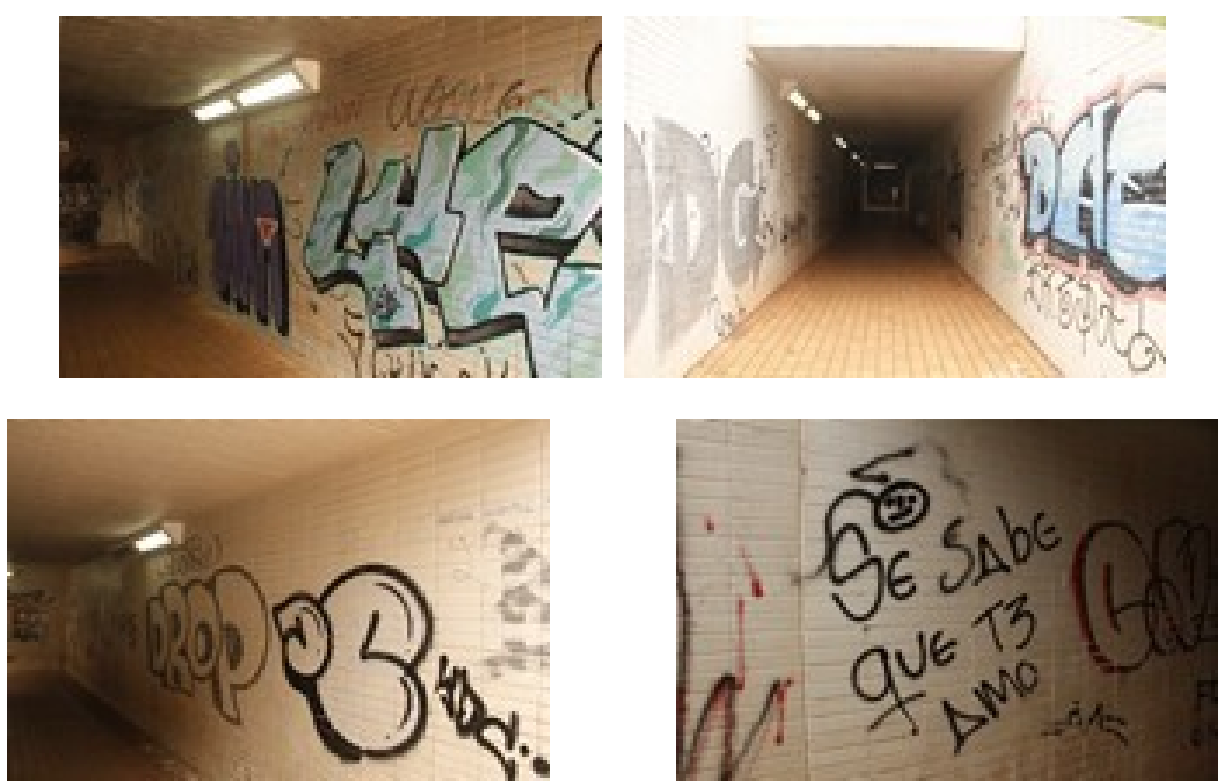

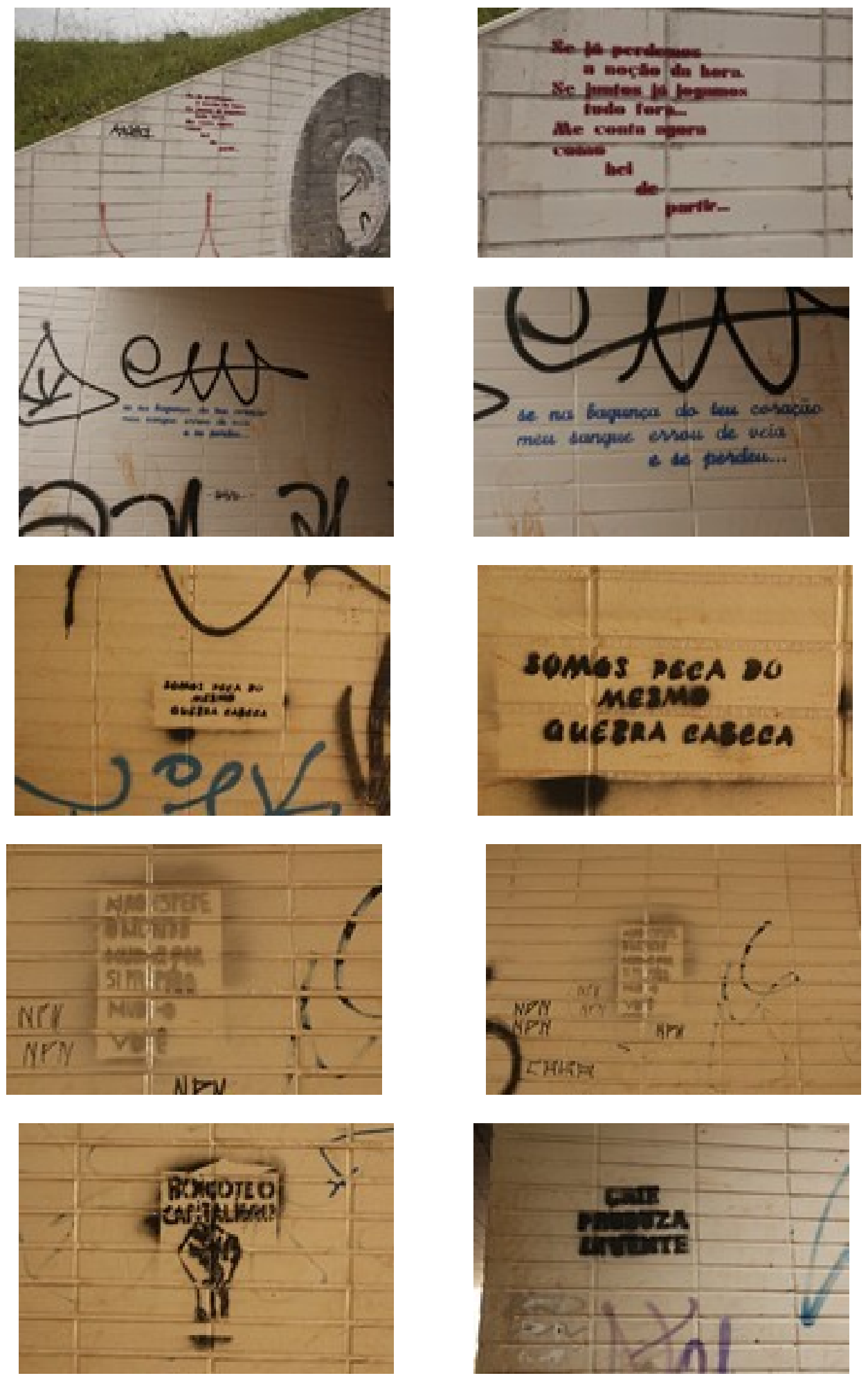

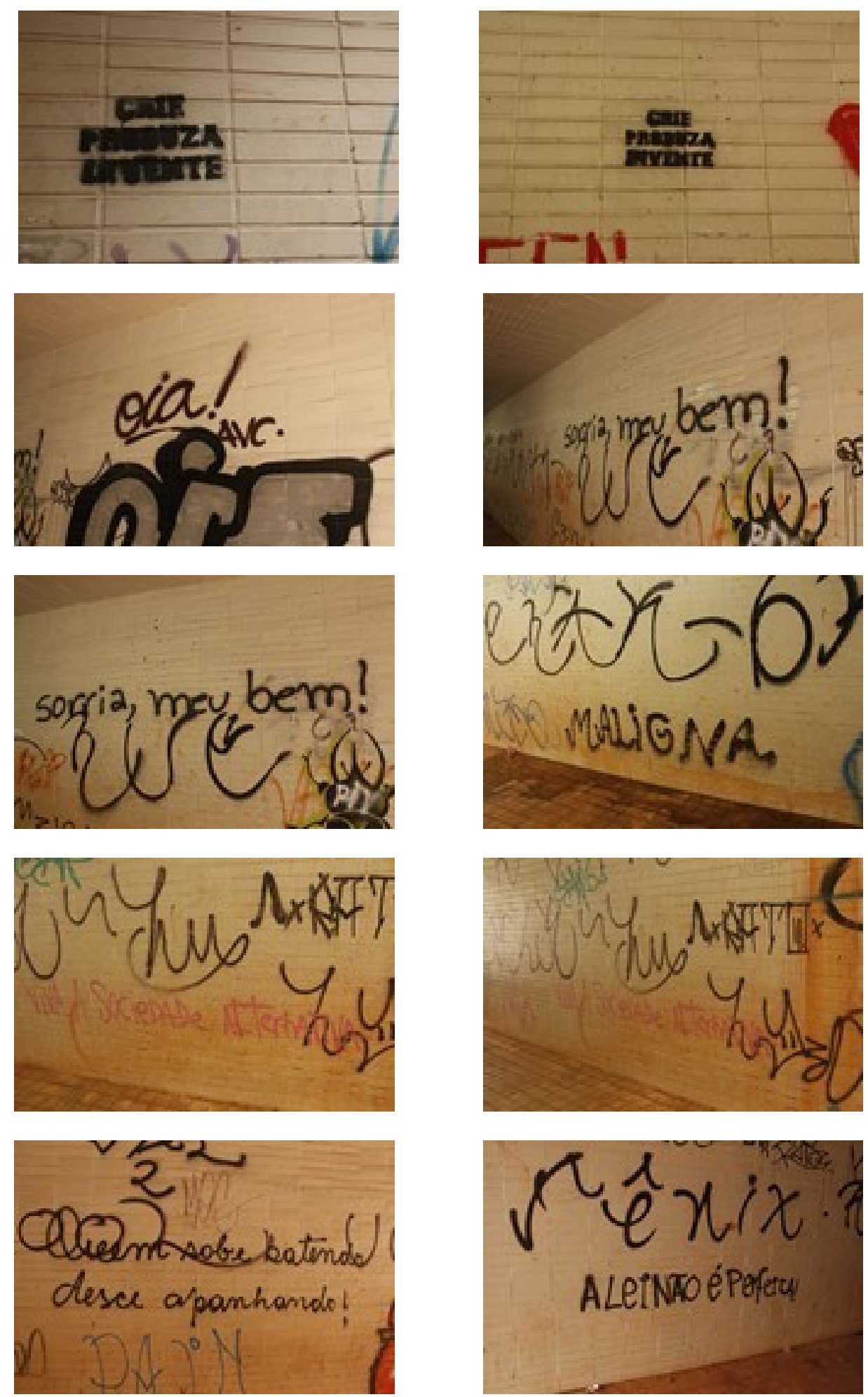

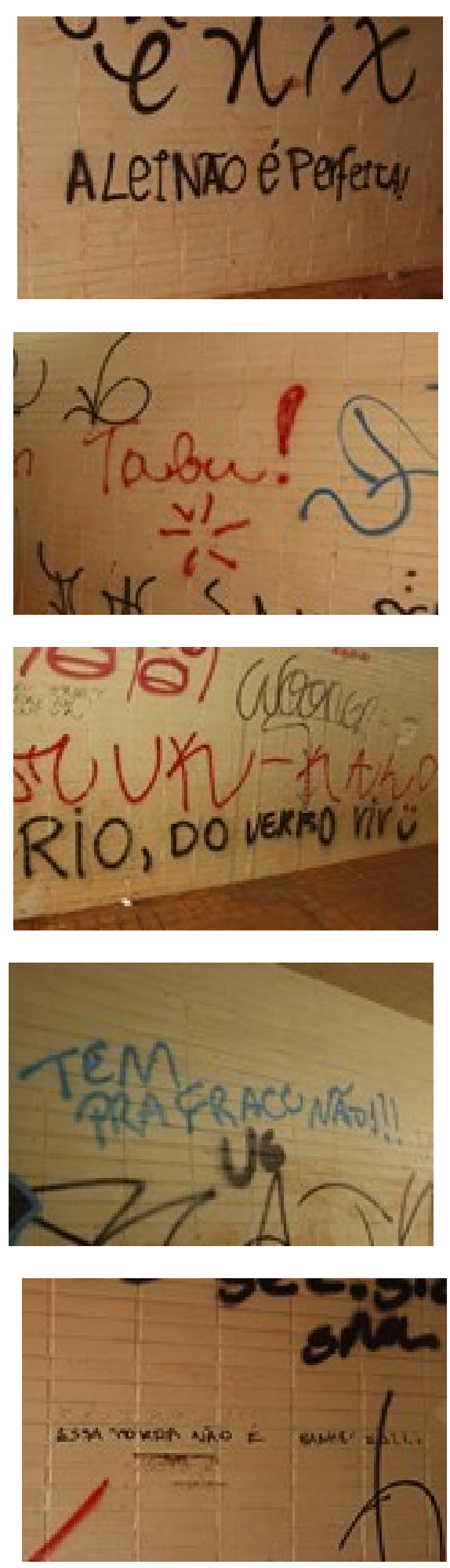
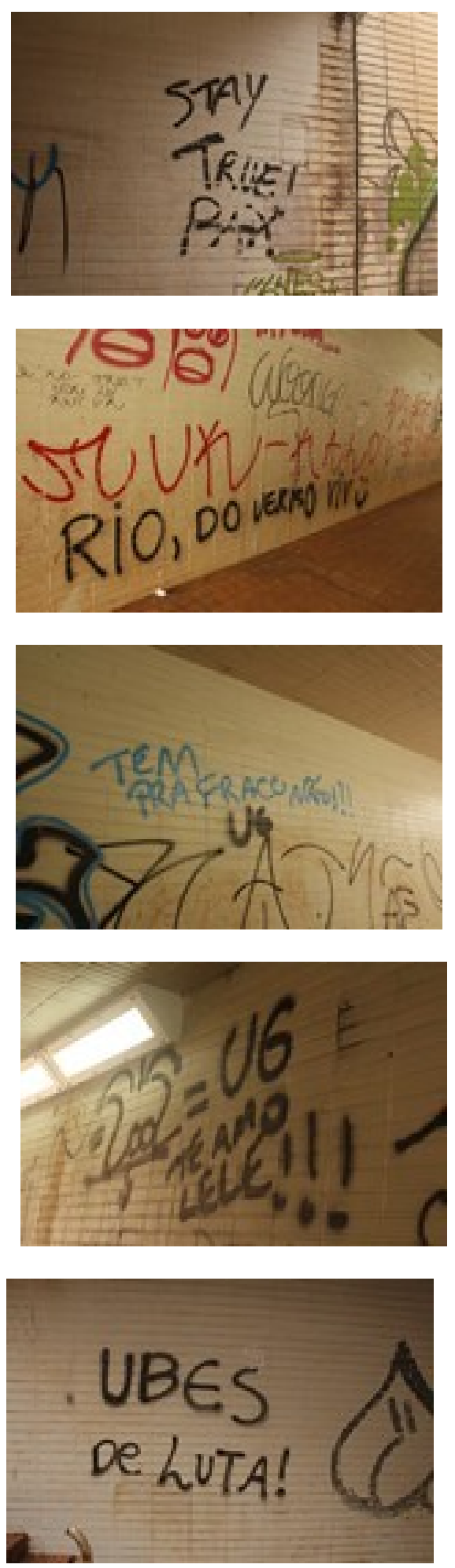

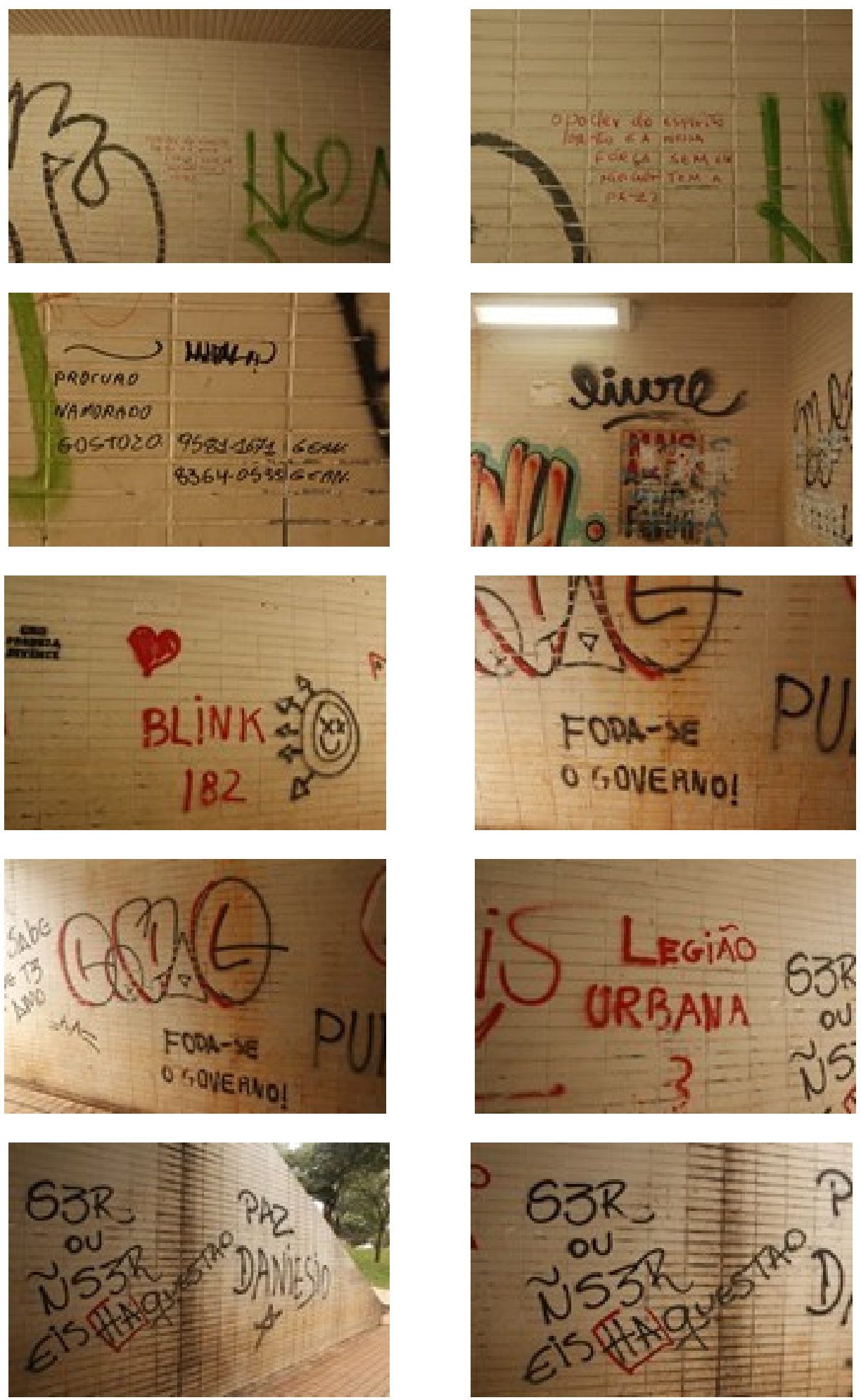

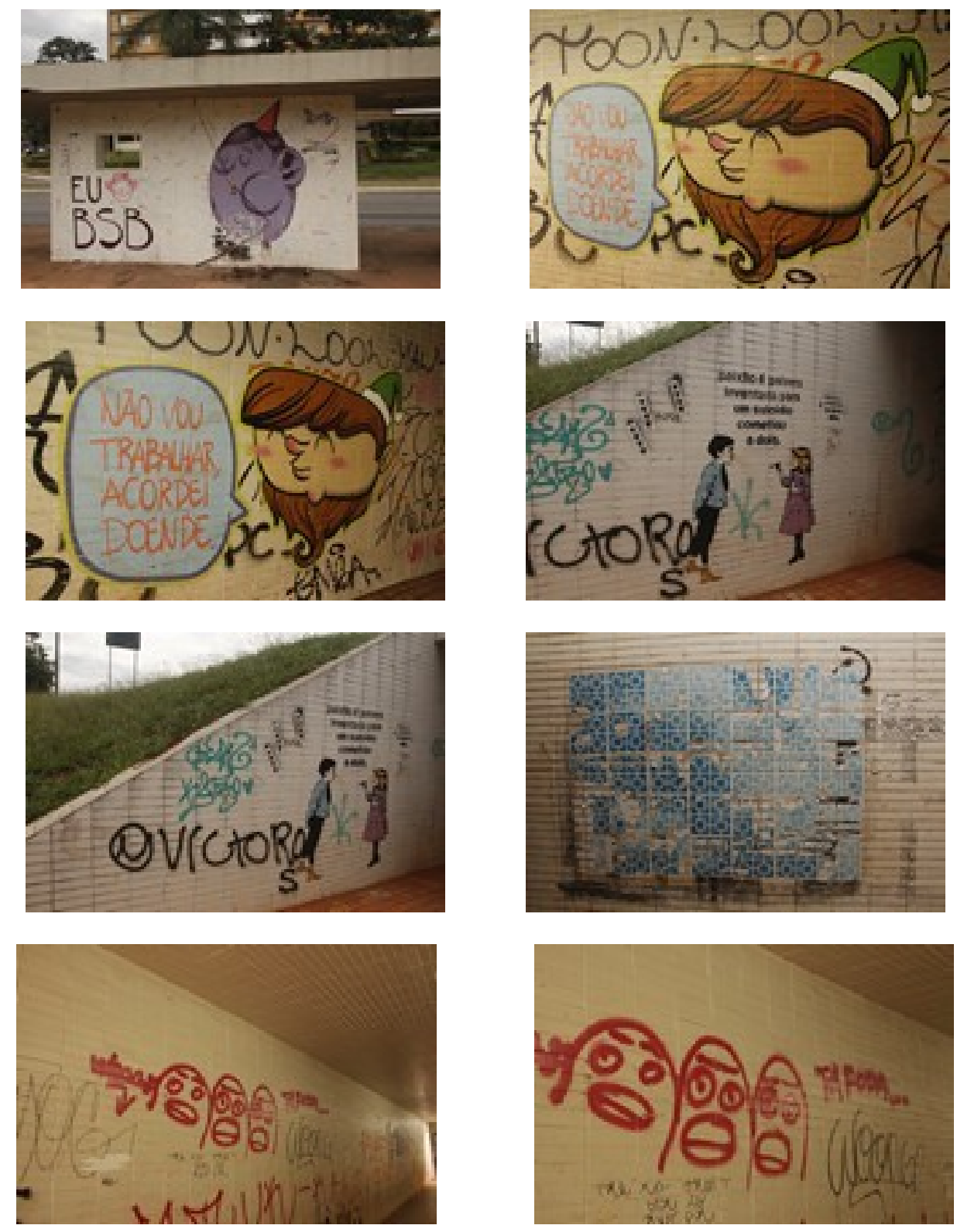

Quadra 102/103, Asa Sul
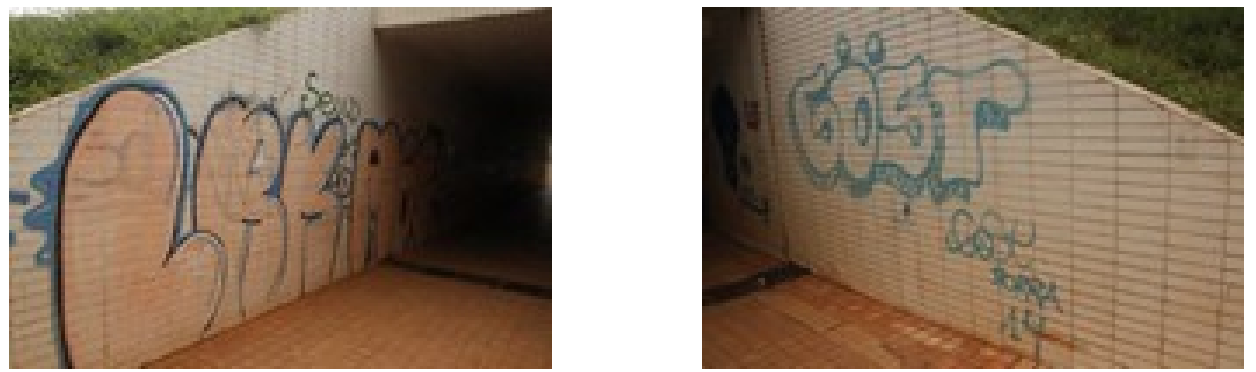

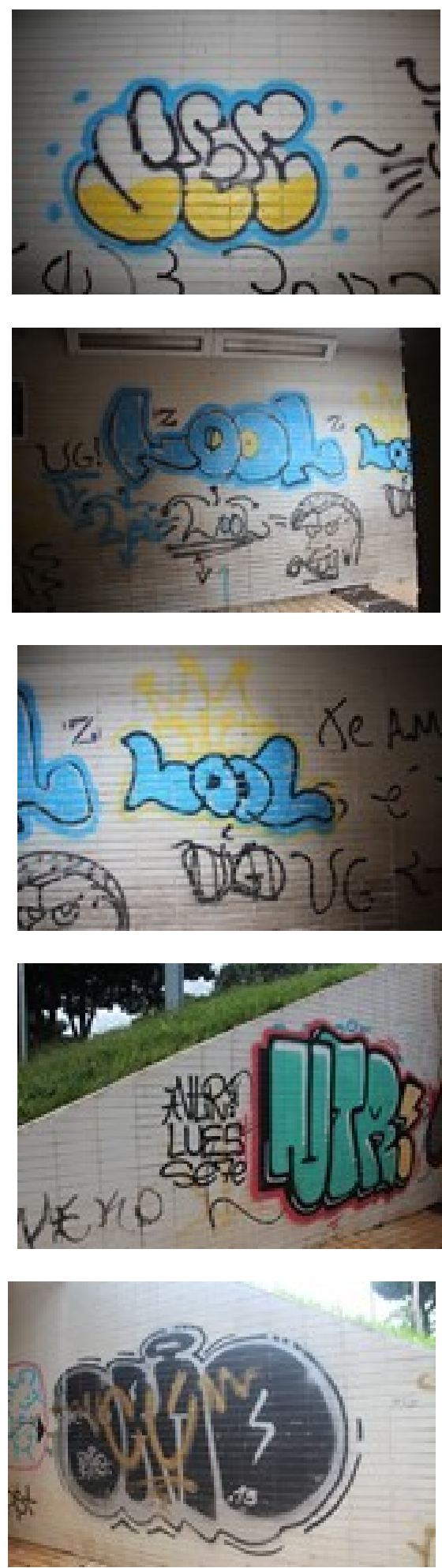
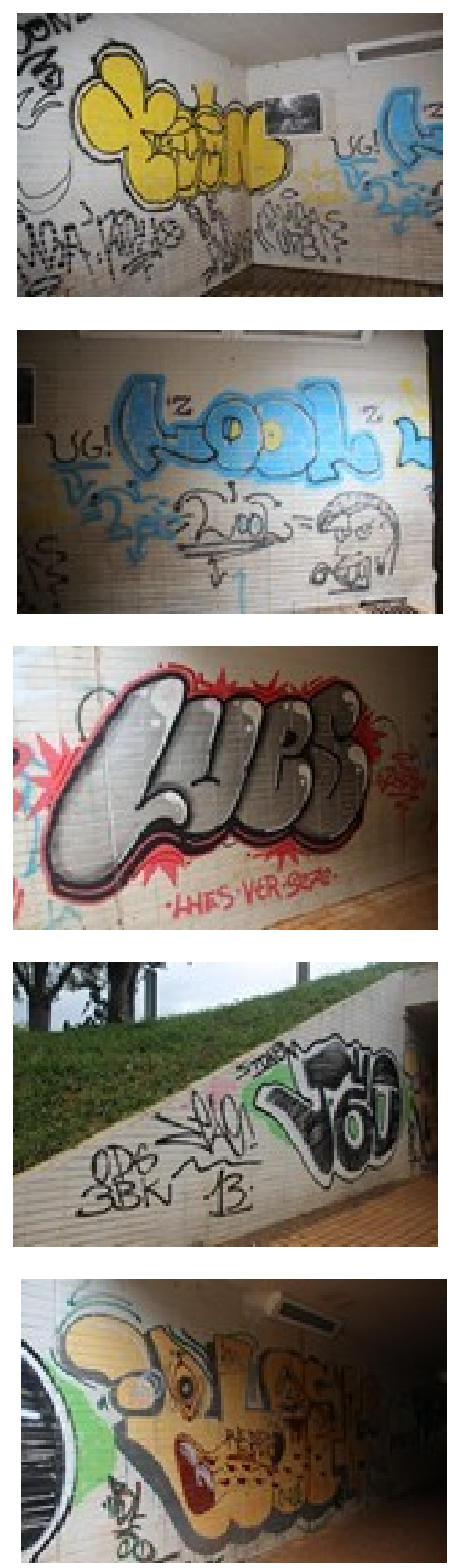

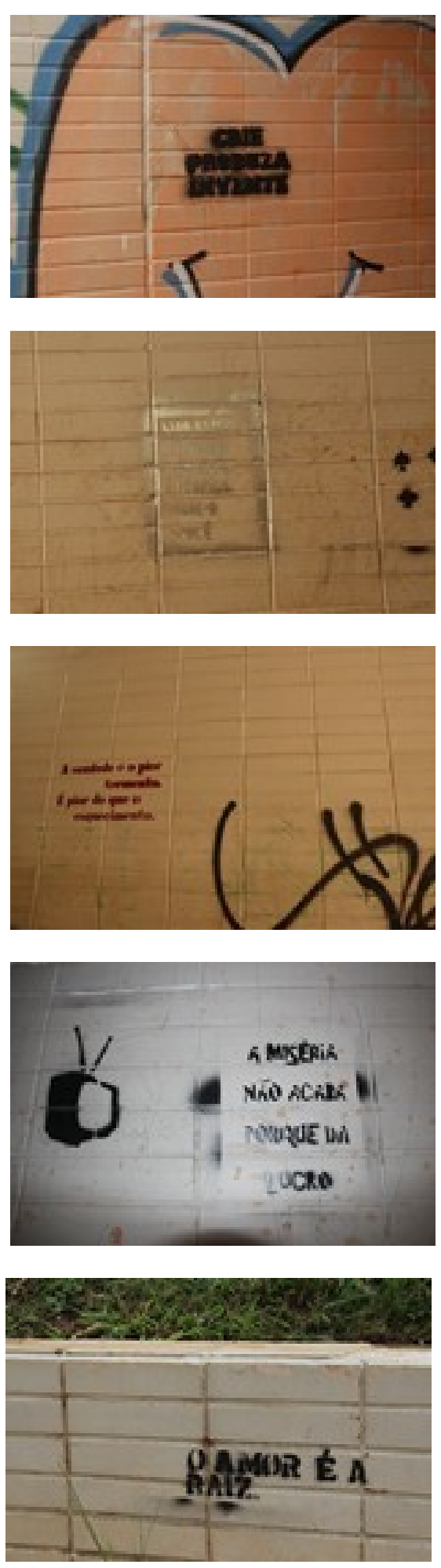
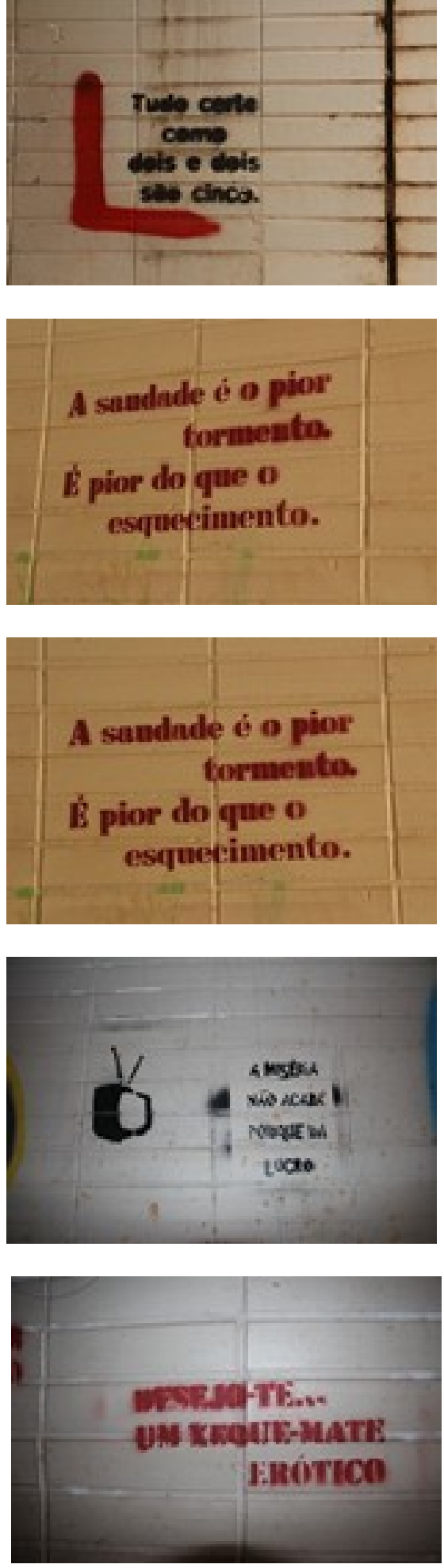

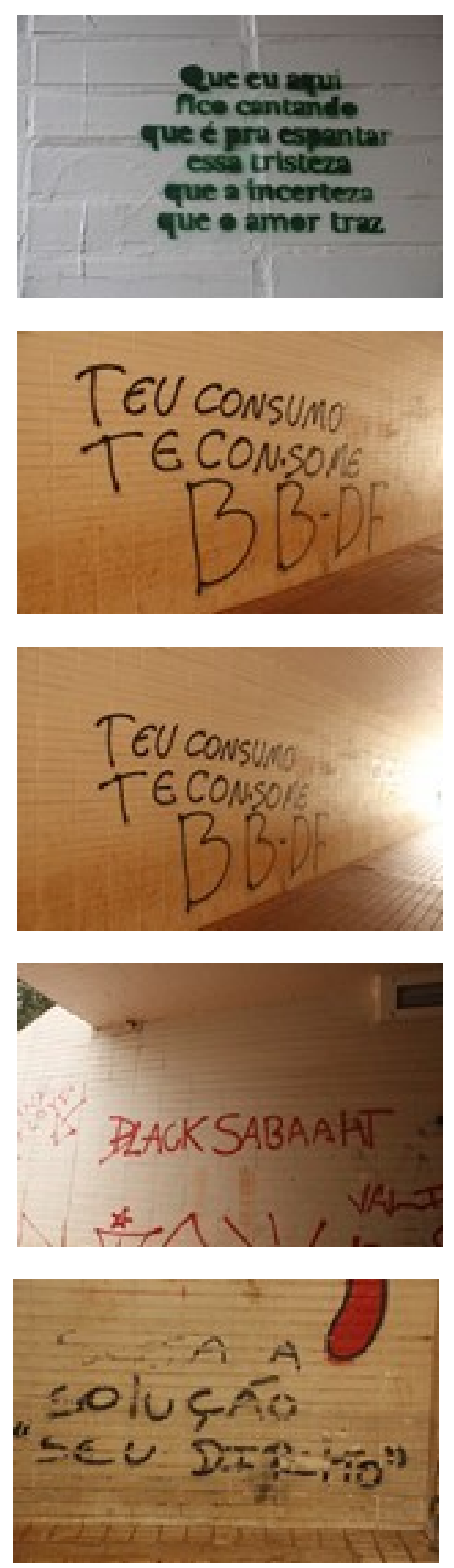
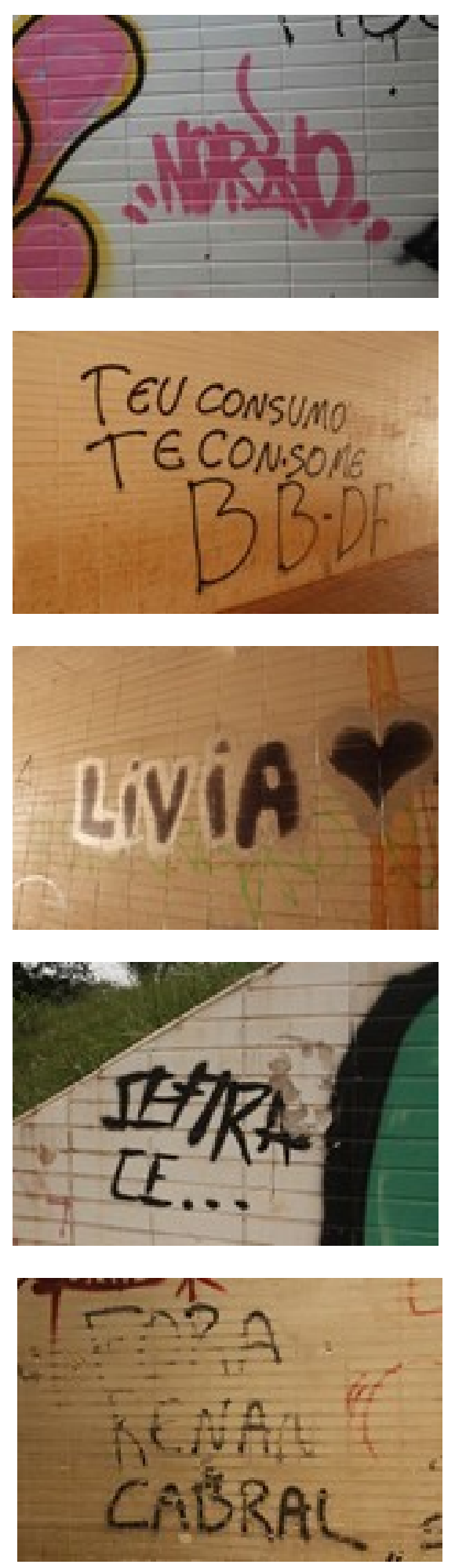


\section{a vida é eonno.}
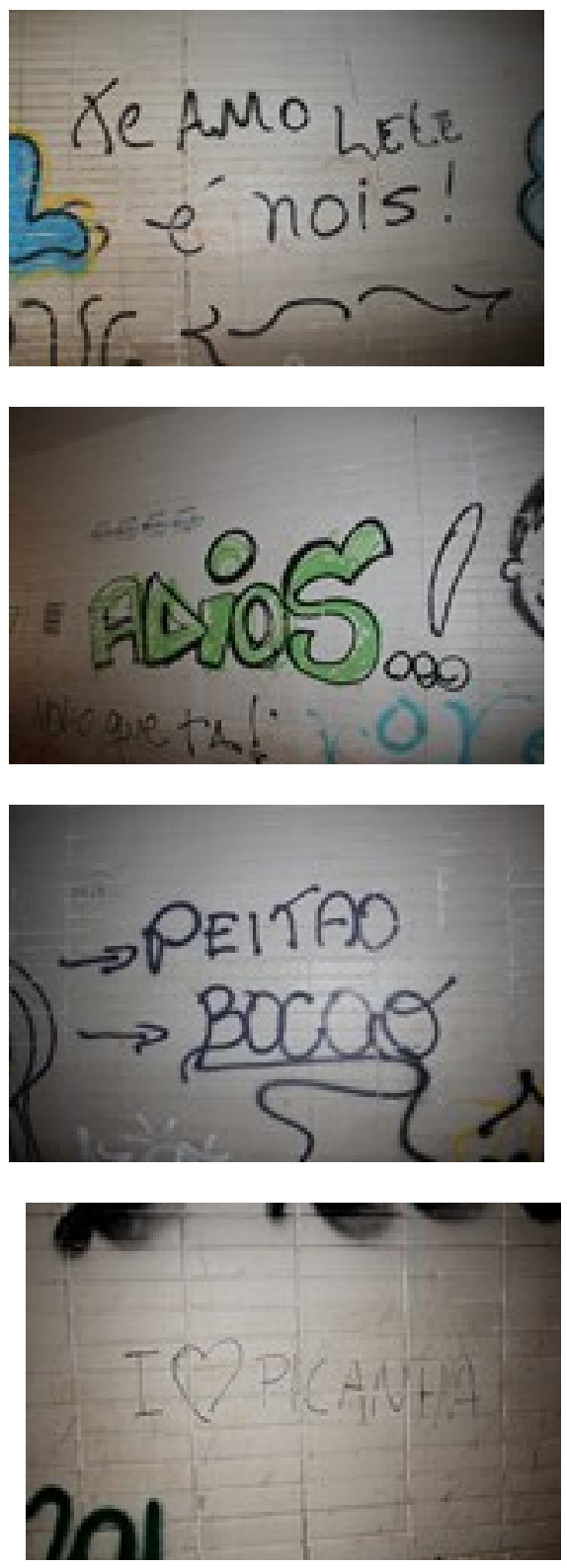
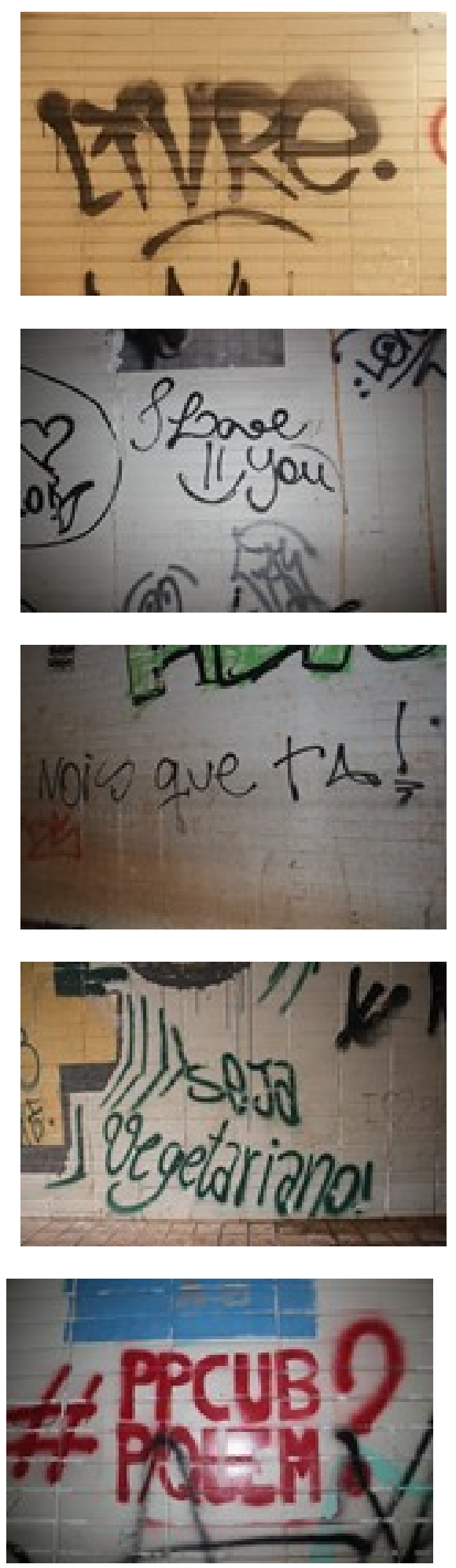

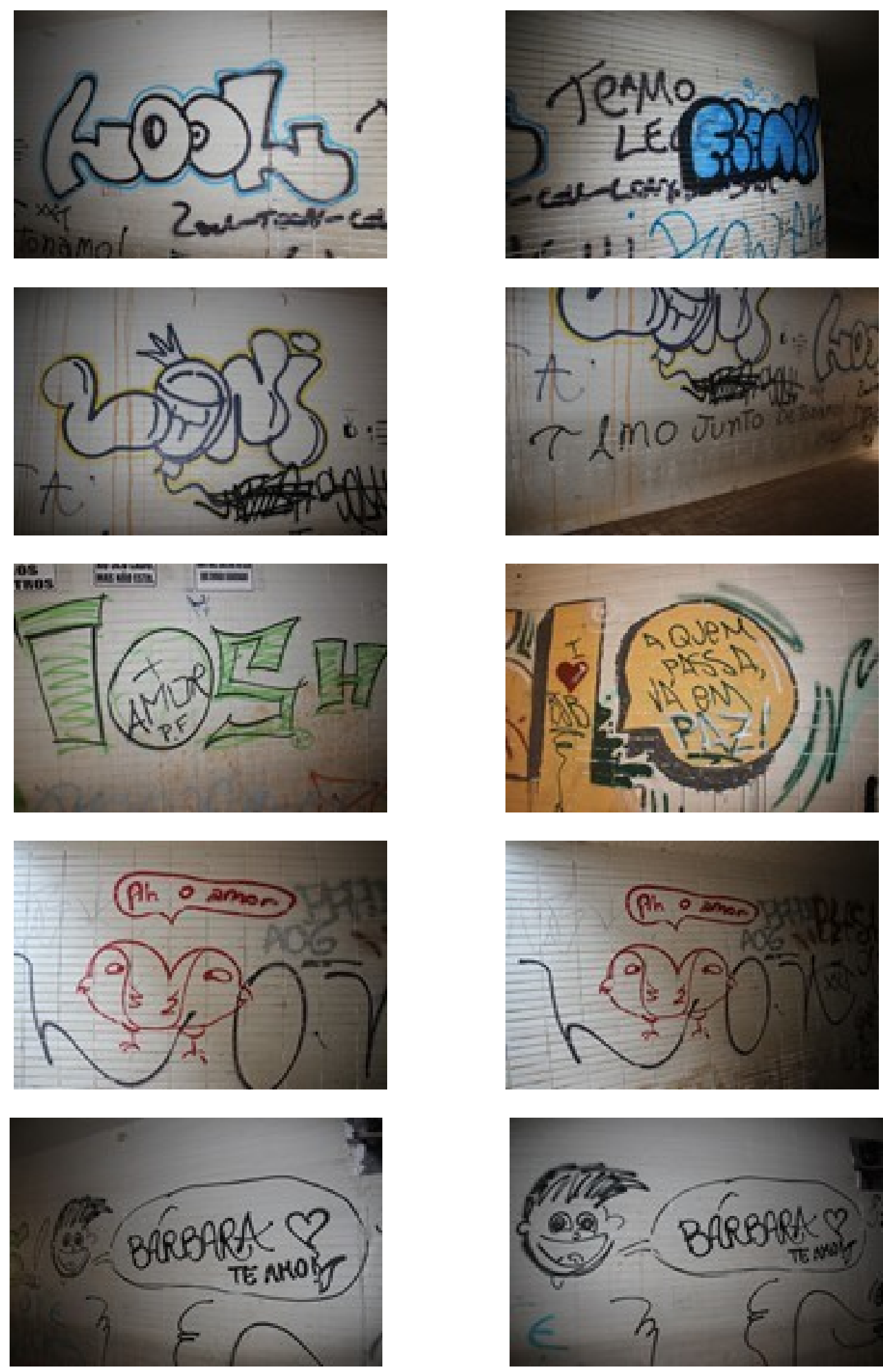

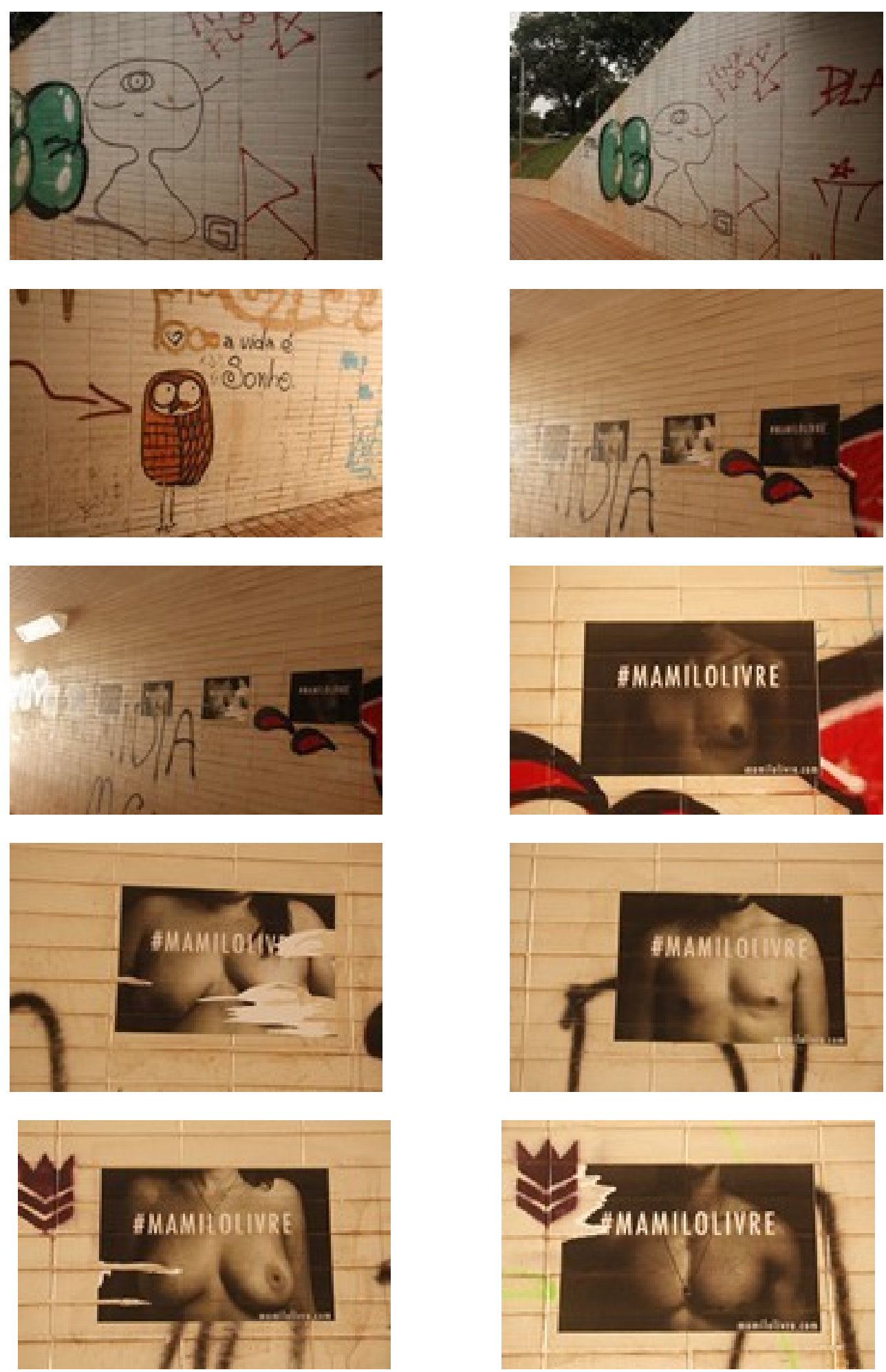

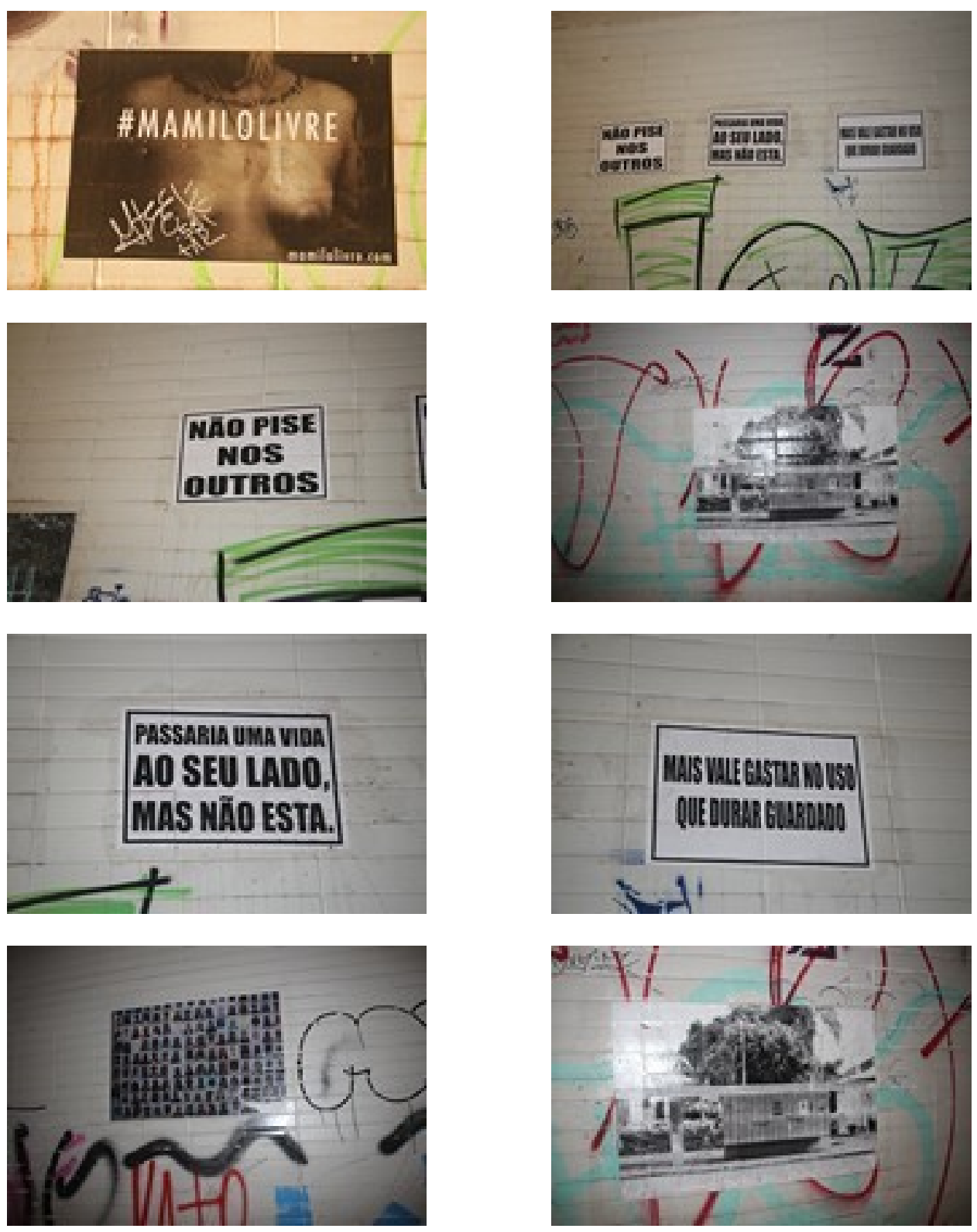